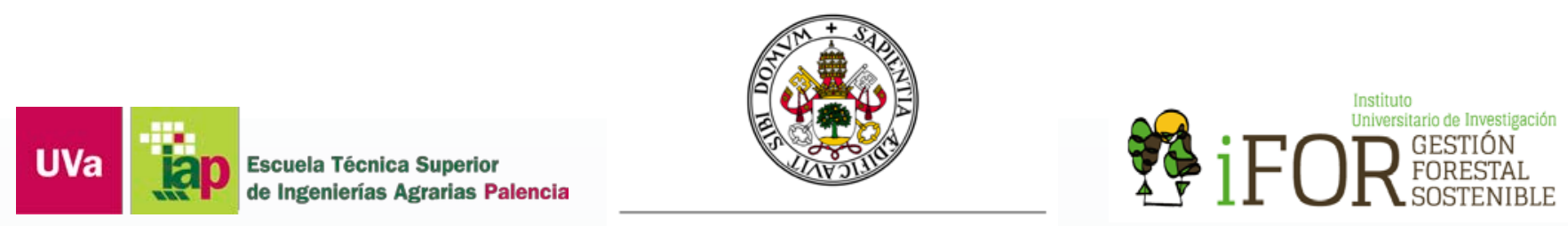

Universidad deValladolid

TESIS DOCTORAL:

\title{
EVALUACIÓN BIOLÓGICA DE ESCALAS DE ARTESAS PARA ALGUNAS DE LAS PRINCIPALES ESPECIES DE PECES IBÉRICOS
}

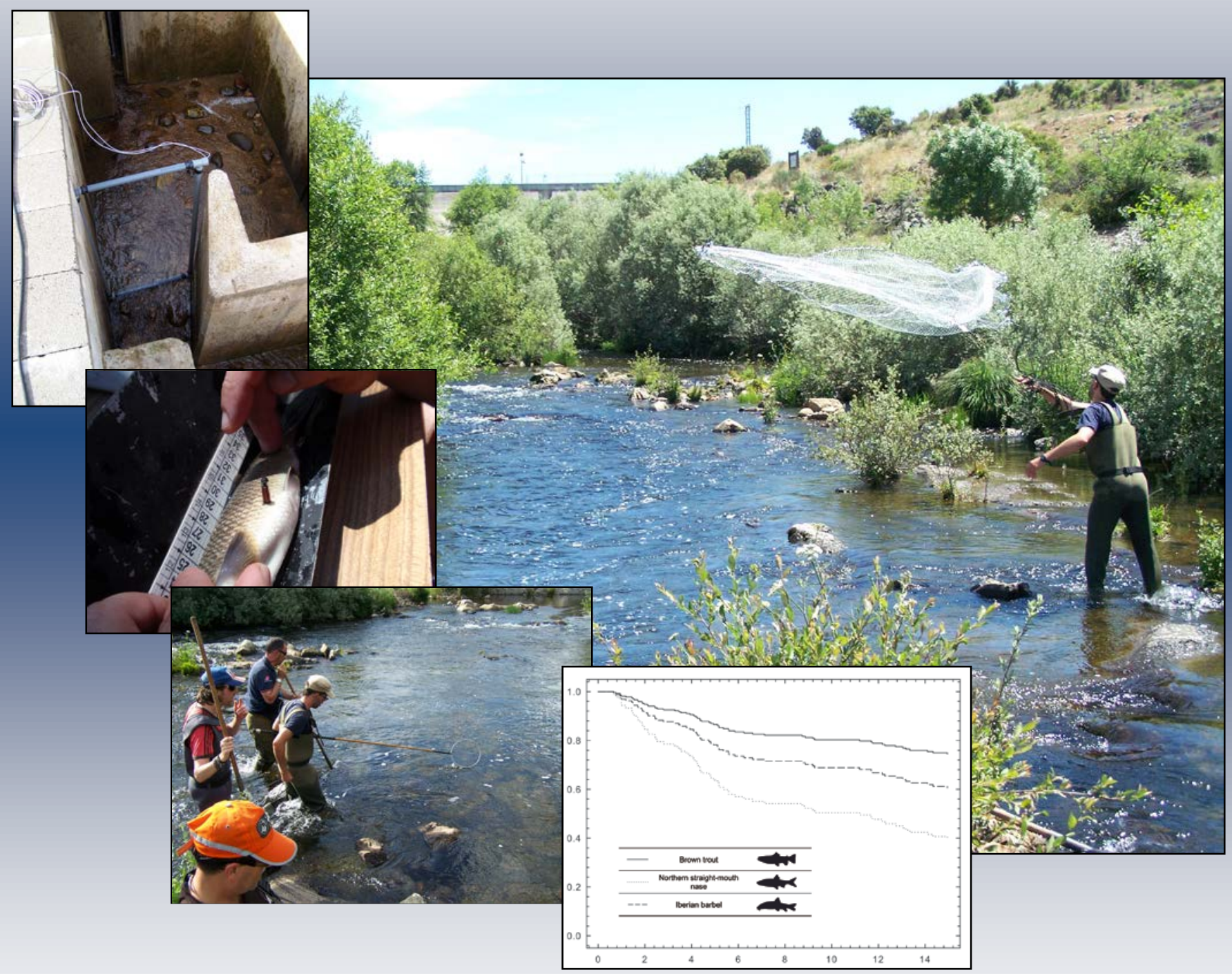

Presentada para optar al grado de doctor por la Universidad de Valladolid por: Francisco Javier Bravo Córdoba

Dirigida por: Francisco Javier Sanz Ronda Sergio Makrakis 

Sólo cuando sepamos podremos comprender mejor lo que sucede, cambiando también lo que somos.

Sólo cuando cambiemos lo que somos cambiaremos lo que podemos.

Ysólo entonces podremos.

Antonio Juriel 



\section{CONTENIDO}

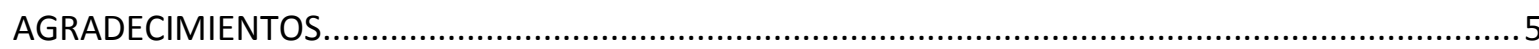

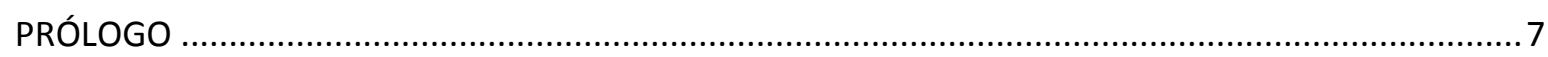

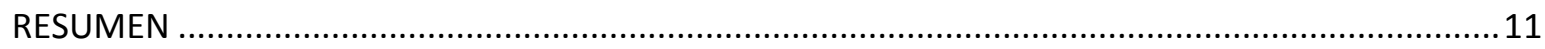

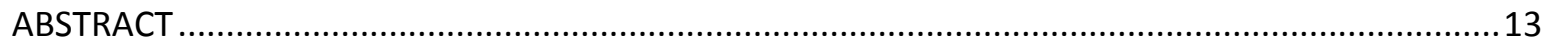

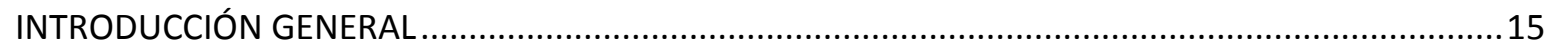

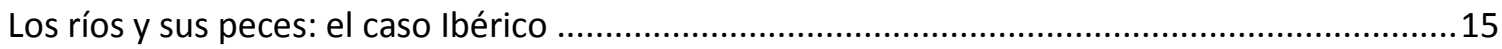

Obstáculos y soluciones al libre movimiento de la ictiofauna ....................................................16

Evaluación biológica de pasos para peces …………............................................................... 19

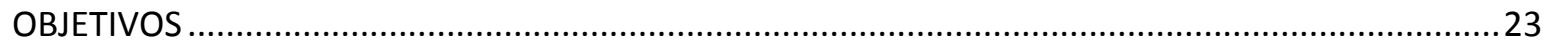

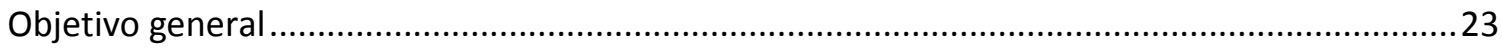

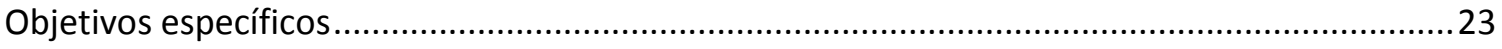

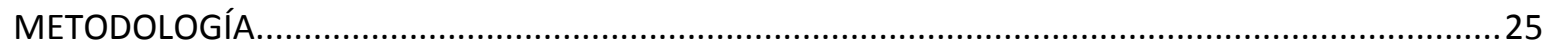

Zona de estudio

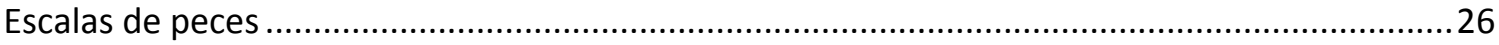

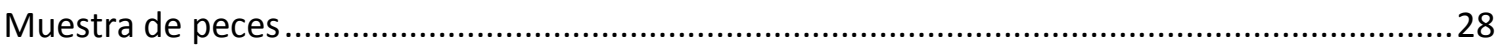

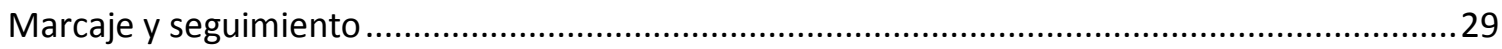

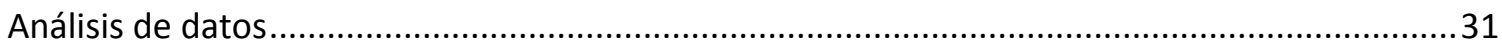

RESULTADOS I: Ascent ability of Brown trout, Salmo trutta, and two Iberian cyprinids -Iberian barbel, Luciobarbus bocagei, and Northern straight-mouth nase, Pseudochondrostoma duriense-

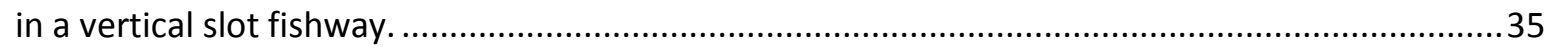

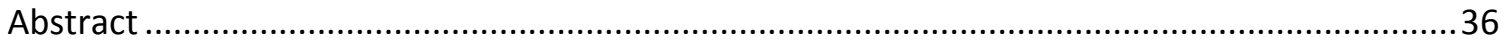

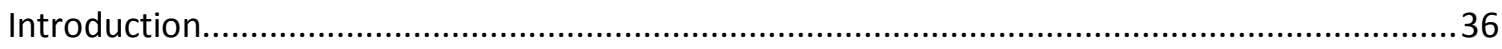

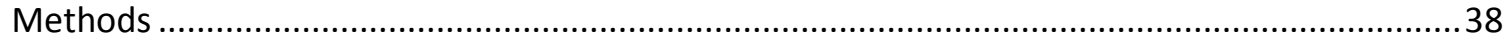




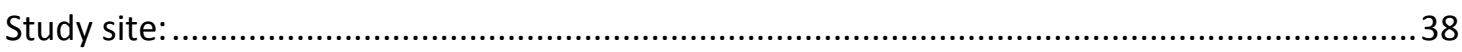

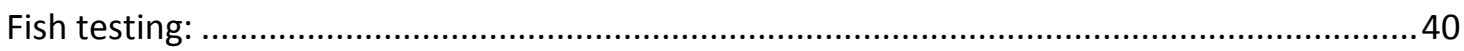

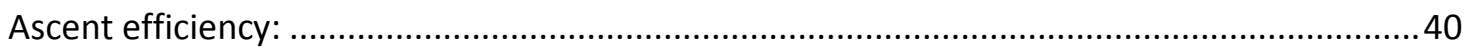

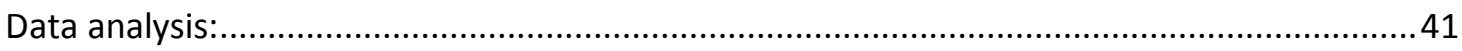

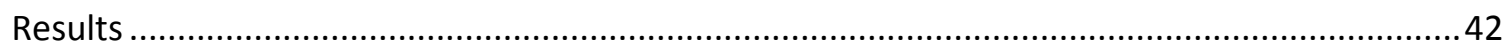

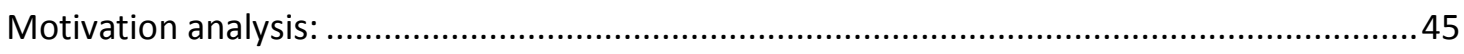

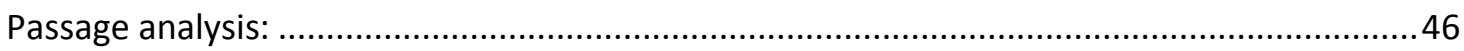

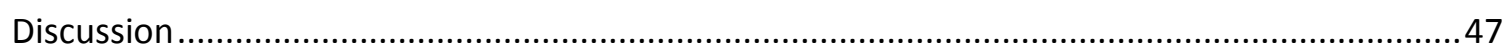

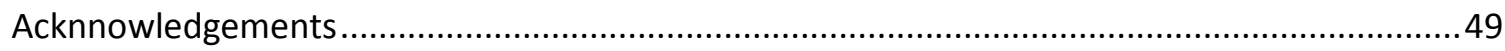

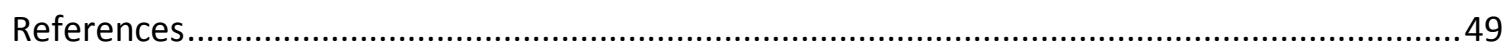

RESULTADOS II: Selecting the best technical fishway design for Iberian barbel, Luciobarbus bocagei (Steindachner, 1864): vertical slots versus submerged notches with bottom orifice..........55

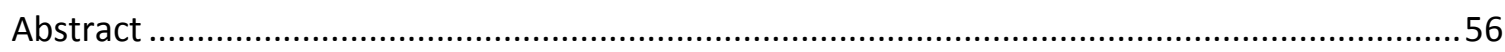

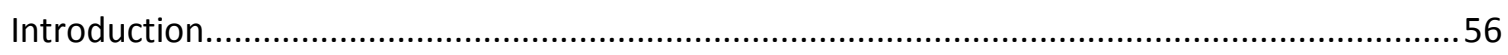

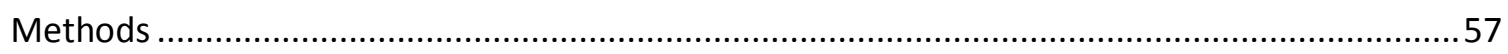

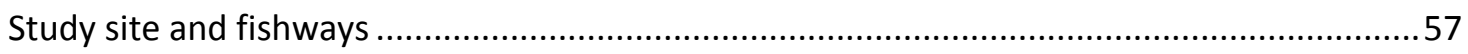

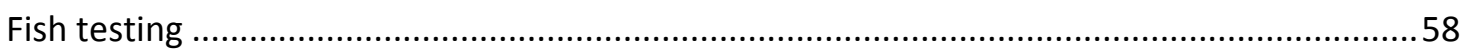

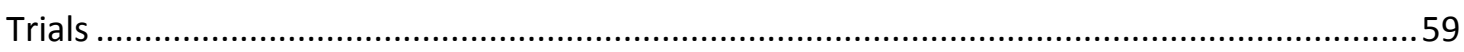

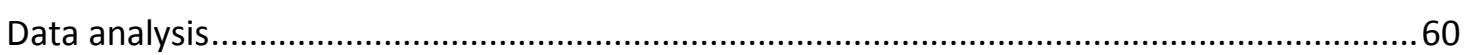

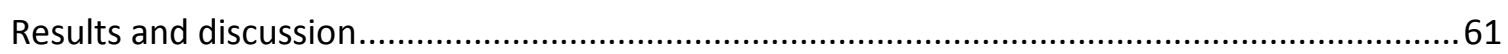

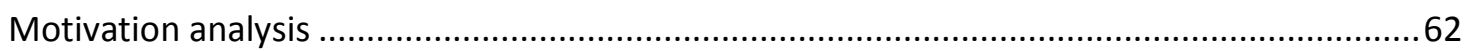

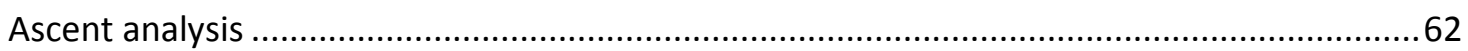

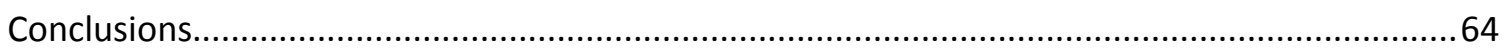

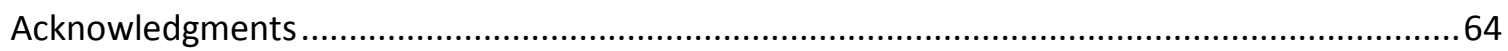

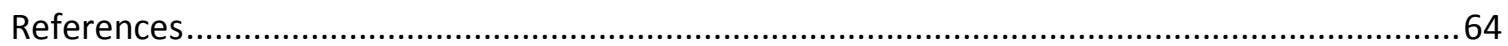


RESULTADOS III: Fishway with two entrance branches: understanding its performance for Iberian barbel, Luciobarbus bocagei (Steindachner, 1864) .....................................................................67

Introduction.

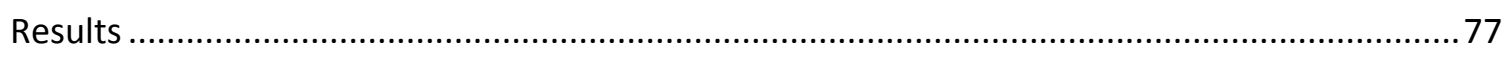

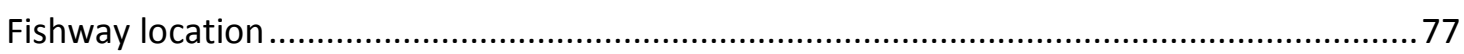

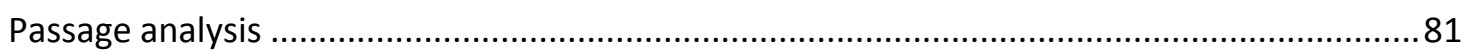

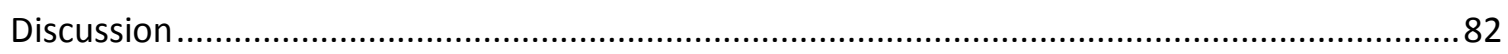

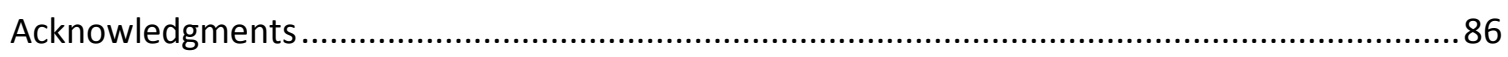

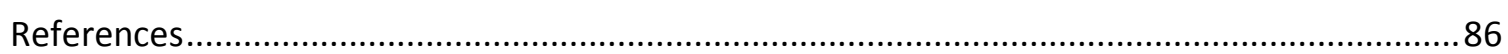

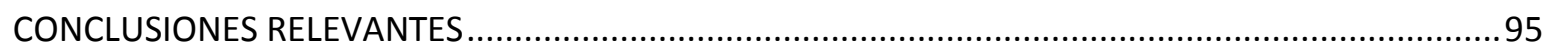

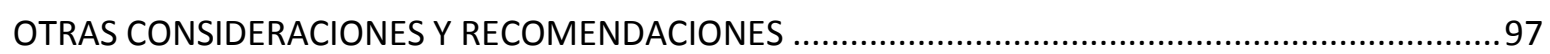

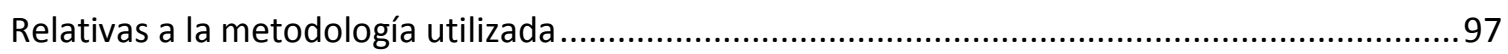

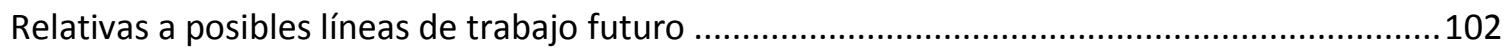

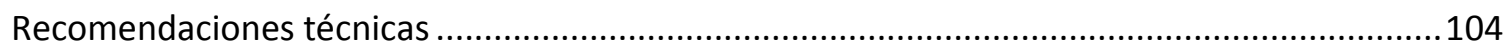

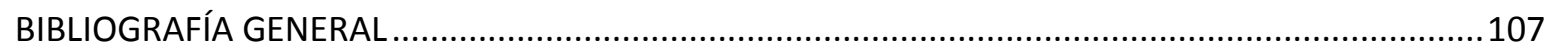

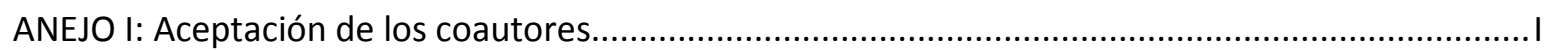

ANEJO II: Copia de la publicación del apartado Resultados I ........................................................... 


\section{AGRADECIMIENTOS}

Javier, gracias por todo. Has conseguido que haya vivido y disfrutado trabajando de lo que me gusta. Porque has formado un grupo de trabajo que ha sido mucho más que eso. Porque te has desvivido por ello, por los ríos y nuestros peces y porque pocas veces se te he reconocido o al menos no todo lo que se debiera. Yo traía la pasión de serie, pero tú la has sabido encauzar y además la has profesionalizado, haciéndonos un hueco en este mundo de la conservación de los ríos y las escalas de peces. Además, gracias por comprender mis otras aficiones y mis tiempos. Ya son casi diez años en los que me has visto y nos hemos visto crecer y espero sean muchos más.

Gracias a los que hemos ido formando GEA. Este trabajo sin vosotras y vosotros: Jorge R., Chafu, Niti, Nuria, Víctor, Jorge V. habría sido imposible. No solo llevarlo a cabo, sino además hacerlo ilusionante, con algunos sufrimientos pero con muchas alegrías, que al menos a mí me han compensado, especialmente por haber construido esta amistad. Todas esas horas en campo, en el coche, en el despacho...no se olvidarán.

Muchas gracias Sergio. Has hecho muy sencillo el trabajo contigo, tu orientación ha sido fundamental en la construcción de todo esto y por supuesto nunca olvidaré todo lo aprendido y especialmente lo vivido en esa estancia paradisiaca en tierras brasileñas.

Muchas gracias al resto que de una u otra manera habéis hecho posible esta investigación. Ted Castro-Santos por una orientación valiosísima y porque pusiste los cimientos. Andrés porque fuiste el pionero de las escalas en este territorio y por todos los consejos de café. Joaquín porque nos atrajiste con tu buenísima docencia y dirección fin de carrera, así como ponerme en manos de Javier.

A mi madre, a mi padre y mi hermana; aquí sí que no hay forma de agradeceros todo lo que os debo. Sois la base de lo que soy, siempre estáis ahí y he tenido vuestro apoyo incondicional. He dedicado mucho tiempo a esto en detrimento vuestro y espero alguna vez poder devolverlo.

Finalmente a Sandra. Has sido mi compañera más cercana en este remontar, la que más ha aguantado esta dedicación y la que me ha sabido reorientar sobre el sentido y la importancia de muchas cosas de la vida y eso no te puedes imaginar lo agradecido que te estaré siempre. 


\section{PRÓLOGO}

El presente trabajo tiene como finalidad analizar el funcionamiento, desde un punto de vista biológico, de algunos de los principales diseños de escalas o pasos para peces.

Con el fin de facilitar la comprensión general y justificar la cohesión temática de los estudios realizados, así como evitar duplicidad innecesaria de información, los sucesivos apartados serán un compendio y justificación de los resultados I, II y III, donde sí aparece reflejado en detalle todo lo referente a las diferentes investigaciones llevadas a cabo. En algunos casos se ha aportado información nueva surgida de la experiencia de trabajo de estos años y que, por la estructura propia de los resultados (formato de artículo de revista), no ha sido posible incorporar a los mismos pero se considera muy importante para el desarrollo de trabajos similares, mejorando la utilidad del documento. Así mismo se han añadido una serie de recomendaciones técnicas que se consideran relevantes a la hora de mejorar la ingeniería de los pasos de peces. La estructura general de la presente tesis obedece tanto a las indicaciones expuestas por la Escuela de Doctorado de la Universidad de Valladolid y el Programa de Doctorado en Conservación y Uso Sostenible de Sistemas Forestales, como a la necesidad e interés científico de que las investigaciones llevadas a cabo puedan ser publicadas en medios de calidad contrastada.

Esta tesis ha sido realizada en el marco del Programa de Doctorado en Conservación y Uso Sostenible de Sistemas Forestales, en la Escuela Técnica Superior de Ingenierías Agrarias de Palencia (Universidad de Valladolid), dentro de la Unidad Docente de Hidráulica e Hidrología y del grupo de investigación GEA-Ecohidráulica.

El autor ha sido financiado con una beca de investigación de la Universidad de Valladolid en su modalidad de becas de Formación para Personal de Investigación (FPI-UVa 2011).

Los estudios realizados durante este tiempo han dado lugar a tres documentos científicos propios de la presente tesis (incluidos aquí como resultados), uno ya aceptado en revista indexada en el Science Citation Index (SCI) (Ver resultados I) y los otros dos en fase de revisión (ver resultados II y III). Se adjunta como documentación complementaria (ver Anejo I) el consentimiento de los diferentes coautores para que dichos capítulos formen parte de la presente tesis doctoral y la renuncia a ser utilizados como publicaciones en otras tesis doctorales. 
- Sanz-Ronda F.J., Bravo-Córdoba F.J., Fuentes-Pérez J.F. and Castro-Santos T. 2016. Ascent ability of Brown trout, Salmo trutta, and two Iberian cyprinids -Iberian barbel, Luciobarbus bocagei, and Northern straight-mouth nase, Pseudochondrostoma duriense- in a vertical slot fishway. Knowledge and Management of Aquatic Ecosystems. 417, 10. DOI: 10.1051/kmae/2015043. Acceptation date Dec 9, 2015.

IF-JCR $2014=0.93$ [Rank 35/52 Fisheries] / SJR 2014: 0.42 [Rank 73/187 in Environmental Engineering]

Bravo-Córdoba F.J., Sanz-Ronda F.J., Ruiz-Legazpi J., Valbuena-Castro J. and Makrakis S. Selecting the best technical fishway design for Iberian barbel, Luciobarbus bocagei (Steindachner, 1864): vertical slots versus submerged notches with bottom orifice.

En fase de revisión. Enviado a la revista Ecological Engineering.

Bravo-Córdoba F.J., Sanz-Ronda F.J., Ruiz-Legazpi J., Celestino I. and Makrakis S. Fishway with two entrance branches: understanding its performance for Iberian barbel, luciobarbus bocagei (Steindachner, 1864).

Última fase de revisión interna. Para enviar a la revista Hydrobiologia.

Además es variada la producción científica relacionada con la temática presente en la que se ha participado durante la elaboración de la tesis:

*Artículos científicos y comunicaciones relevantes

- Sanz-Ronda F.J., Ruiz-Legazpi J., Bravo-Córdoba F.J., Makrakis S. and Castro-Santos, T. 2015. Sprinting performance of two Iberian fish: Luciobarbus bocagei and Pseudochondrostoma duriense in an open channel flume. Ecological Engineering, 83, 61-70. doi:10.1016/j.ecoleng.2015.05.033

Bravo-Córdoba F.J., Sanz-Ronda F.J., Fuentes-Pérez J.F., Ruiz-Legazpi J., Salgado V., García-Vega A., Valbuena-Castro J. and Peña-Garrido A. 2015. Fishway with two entrance locations. Fish Passage 2015. Groningen, Netherlands.

- Sanz-Ronda F.J., Bravo-Córdoba F.J., Ruiz-Legazpi J. and Fuentes-Pérez J.F. 2015. The most evaluated fishway in Spain: A new lesson every year. Fish Passage 2015. Groningen, Netherlands.

- Ruiz-Legazpi J., Sanz-Ronda F.J., Bravo-Córdoba F.J., Makrakis S. and Castro-Santos T. 2015. Influence of biometric parameters, flow condition and water temperature on Iberian fish sprinting behavior: volitionally swimming performance. Fish Passage 2015. Groningen, Netherlands.

- Sanz-Ronda F.J., Bravo-Córdoba F.J. Fuentes-Pérez J.F., Ruiz-Legazpi J., García-Vega A.; Ramos-González N., Salgado-González V. and Martínez De Azagra A. 2013. Pasos para peces: escalas y otros dispositivos de paso. Notas técnicas del CIREF, no7. 
Bravo-Córdoba F.J and Sanz-Ronda, F. J. 2012. Eficiencia de ascenso de la trucha común (Salmo trutta) en una escala de peces de hendiduras verticales: la influencia del sexo, la edad, el caudal y las condiciones de experimentación. IV Jornadas Ibéricas de Ictiología. SIBIC. Gerona.

- Sanz-Ronda F.J., Bravo Córdoba F.J. and Martínez De Azagra A. 2010. Estaciones de aforo v-flat y peces migradores de la península ibérica: problemas y soluciones. Ingeniería civil. CEDEX. 158, 11-121.

\section{*Premios}

- DISTINGUISHED PROJECT IN FISHERIES ENGINEERING AND ECOHYDROLOGY AWARD 2015. Otorgado por la American Fisheries Society (AFS) y el Environmental Water Research Institute (EWRI-ASCE) en el V Congreso Mundial de Pasos para Peces celebrado en Groningen (Holanda). Junio 2015.

- PREMIO INNOVADORES 2014, otorgado por el Diario El Mundo al grupo GEA-Ecohidráulica, a los mejores proyectos de I+D+i de Castilla y León

Por último, mencionar la participación en proyectos técnicos de diseño, ejecución y evaluación de escalas de peces y obstáculos a la migración que se consideran relevantes de mención por las sinergias, experiencias y aportaciones relevantes a la presente tesis:

\section{- LIFE RIVERLINK}

Entidad Financiadora: Unión Europea

Entidades participantes: CHS, Universidad de Murcia, Universidad de Valladolid, Itagra.ct, ANSE, Gobierno de Murcia.

Duración. Desde: 2013 Hasta: 2017

Investigadores Principales: Eduardo Lafuente

Tipo de participación: ejecución de varias acciones (proyectos y evaluación de pasos para peces)

Cuantía total: 3.424.250€

- DESARROLLO Y APLICACIÓN DE UNA METODOLOGía PARA LA EVALUACIÓN DE PASOS PARA PECES EN LA CUENCA DEL DUERO

Entidad Financiadora: Ministerio de Medio Ambiente, Medio Rural y Marino-Confederación Hidrográfica del Duero

Entidades participantes: Universidad de Valladolid e Itagra.ct.

Duración. Desde: 2014-actualidad.

Investigadores Principales: Francisco Javier Sanz Ronda

Tipo de participación: evaluación de pasos para peces y manual metodológico

Cuantía total: $60.500 €$

- DETERMINACIÓN DE LA CAPACIDAD DE NADO DE PECES IBÉRICOS

Entidad Financiadora: Junta de Castilla y León (Ref: VA-299B11 -2 C.Unesco: 3105.04)

Entidades participantes: Universidad de Valladolid, Savasa, Itagra.ct, PAYD

Duración: 2 años (2011-2012)

Investigador Principal: Fco. Javier Sanz-Ronda

Tipo de participación: experimentación y procesado de datos

Cuantía total: $30.000 €$

- EVALUACIÓN HIDRÁULICA Y BIOLÓGICA DE PASOS PARA PECES EN CENTRALES HIDROELÉCTRICAS

Entidad Financiadora: Iberdrola Renovables S.A.

Entidades participantes: Itagra.ct 
Duración: Marzo 2013 - actualidad

Investigador Principal: Fco. Javier Sanz-Ronda

Tipo de participación: experimentación, procesado de datos y redacción de informes

Cuantía total: $78.240 €$

- ESTUDIO, SEGUIMIENTO Y MONITORIZACIÓN DE LA ESCALA DE PECES DE LA CENTRAL HIDROELÉCTRICA DEL SALTO DE SAN FERNANDO (RÍO TORMES, SALAMANCA)

Entidad Financiadora: Salto de San Fernando S.L.

Entidades participantes: Itagra.ct

Duración: Enero 2012 - actualidad

Investigador Principal: Fco. Javier Sanz-Ronda

Tipo de participación: experimentación, procesado de datos y redacción de informes

Cuantía total: $39.847 €$

- SOLUCIONES A LA MIGRACIÓN PISCÍCOLA EN DIVERSOS RÍOS DE LA CUENCA DEL JÚCAR Y DEL EBRO

Entidad Financiadora: Tecnoma, Confederación Hidrográfica del Júcar y Confederación Hidrográfica del Ebro

Entidades participantes: Itagra.ct

Duración: Diciembre 2010

Investigador Principal: Fco. Javier Sanz-Ronda

Tipo de participación: procesado de datos y diseño de soluciones

Cuantía total: $36.878 €$

- ESTUDIO PARA LA ADAPTACIÓN A LA MIGRACIÓN DE LA ICTIOFAUNA DE ESTACIONES DE AFORO V-FLAT

Entidad Financiadora: UTE Cuenca Duero y Confederación Hidrográfica del Duero Entidades participantes:

Itagra.ct

Duración: Diciembre 2009

Investigador Principal: Fco. Javier Sanz-Ronda y Joaquín Navarro Hevia

Tipo de participación: experimentación, procesado de datos, diseño de soluciones y redacción de informes

Cuantía total: $30.000 €$ 


\section{RESUMEN}

Los ríos son fuente de recursos y sumidero de impactos a partes iguales. En la Península Ibérica, con un clima mediterráneo dominante y por tanto una estacionalidad climática tan acusada, las obras de regulación y control de cauces han sido protagonistas desde hace siglos. Estas actuaciones, además de muchos beneficios, también suponen importantes impactos como la ruptura en la continuidad longitudinal, afectando entre otros al libre movimiento de la ictiofauna. Con el fin de solucionar o mitigar dichos efectos negativos se han diseñado y ejecutado pasos o escalas de peces.

Hasta la fecha y especialmente en el ámbito español, son muy pocos los estudios que analicen en campo, desde un punto de vista biológico, tanto los obstáculos como las soluciones al movimiento de la ictiofauna. Por todo ello, con el presente trabajo, se ha profundizado en una metodología y análisis de resultados adecuados para tal fin. Para ello, se ha trabajado fundamentalmente con sistemas de seguimiento de fauna a través de tecnología PIT-tag (Passive Integrated Transponder) -microchips pasivos, equipos de antenas y datalogger- instalados en las propias escalas de peces. Las investigaciones se han centrado en los movimientos migratorios ascendentes, analizando según el caso el comportamiento de tres de las principales especies ibéricas: barbo Ibérico (Luciobarbus bocagei), boga del Duero (Pseudochondrostoma duriense) y trucha común (Salmo trutta). Se han utilizado diferentes técnicas de captura -pesca eléctrica, redes, trampas- y experimentación -estabulada y libre-.

En la obtención de resultados ha sido fundamental investigar e implementar métodos estadísticos no convencionales debido a las particularidades de los datos obtenidos y los resultados de interés. La estadística de supervivencia ha sido la que mejor se ha adaptado por lo siguiente: permite analizar lo que sucede a lo largo de una línea temporal, incluir en el análisis individuos que no participan en los ensayos -eventos censurados- e individuos con más de un intento -eventos repetidos-, el efecto de variables que cambian según avanza el tiempo -variables dependientes del tiempo -, la toma de decisiones excluyentes entre sí -riesgos competitivos- y modelizar comportamientos que no siguen una distribución normal.

Las escalas de peces en las que se ha trabajado están localizadas en la cuenca del Duero. Son pasos para peces del tipo "técnicos" o "divididos en artesas o estanques sucesivos" y, más en 
concreto de la tipología: vertederos sumergidos con orificios de fondo (dos) y hendiduras verticales (dos).

Los principales resultados obtenidos están relacionados con la motivación y el ascenso de las escalas de peces (experimentos con peces estabulados y libres) y la localización del paso (experimentos con peces libres). Se ha comparado el funcionamiento de la escala de hendiduras verticales para las tres especies y en el caso del barbo se ha podido estudiar su rendimiento en las dos tipologías de escala, así como analizar la localización y paso en una escala con dos ramales de entrada. También se ha investigado sobre el efecto de diferentes variables bióticas (longitud del pez) y abióticas (caudal, temperatura del agua, presión atmosférica, velocidad del agua) en el comportamiento de los peces.

Se ha observado que los ciprínidos ibéricos reófilos estudiados tienen una capacidad de ascenso en estas escalas muy similar a la trucha, incluso superior dependiendo de las circunstancias, en contra de la creencia habitual. En cuanto a los tiempos de ascenso, las diferentes escalas no han supuesto retrasos importantes a la migración (aproximadamente entre 4 y 37 minutos por metro de desnivel superado), teniendo un efecto significativo la presencia de curvas en el diseño de la escala (aumentando el tiempo de ascenso). Entre tipologías, los barbos fueron más rápidos en vertederos sumergidos con orificio de fondo que en hendiduras verticales. En el caso de diseños con más de un ramal de entrada, se ha observado que puede aumentar el porcentaje de éxito de ascenso gracias a la presencia de más de una vía de entrada y se han constatado diferencias en la localización de las mismas en función de las variables ambientales de caudal, temperatura del agua y presión atmosférica; pero con efectos diferenciados según la entrada escogida. El análisis de la longitud ha manifestado un efecto significativo para las hendiduras verticales, donde los barbos de mayor tamaño invirtieron tiempos menores en superarlo.

Este trabajo se espera sirva de ayuda metodológica en el desarrollo de futuras evaluaciones biológicas y los resultados apoyen el diseño de nuevos pasos para peces y/o la mejora de los existentes. 


\section{ABSTRACT}

Rivers are both natural resources and impact areas. The Iberian Peninsula is characterized by the Mediterranean climate and hence a significant climatic seasonality. Therefore, works of river regulation and control have been numerous for centuries. These actions, in addition to many benefits, also involve significant impacts such as longitudinal rupture in the continuity affecting, among others, the free movement of fish fauna. In order to solve or mitigate such adverse effects fish passes have been designed and implemented.

To date, especially in the Spanish context, there are very few field studies from a biological point of view which analyze obstacles and solutions for movement of ichthyofauna. Therefore, the present study has deepened into a suitable methodology and analysis of results for that purpose. For this, it has mainly worked with wildlife tracking systems by PIT-tag technology (Passive Integrated Transponder) -passive microchips, antennas and datalogger- installed on fish ladders. Researches have focused on the upstream migratory movements, analyzing the behavior of three of the main Iberian fish species: Iberian barbel (Luciobarbus bocagei), Duero nase (Pseudochondrostoma duriense) and brown trout (Salmo trutta). We used different capture techniques -electrofishing, nets and traps- and kind of trials -free and non-free movements- .

To get results, it has been very important to research and implement non-conventional statistical methods due to the characteristics of the data. Statistic survival methods have been the most suitable for the following. They allow to analyze what happens along a timeline, to include in the analysis individuals not involved in the trials -censored events- and individuals with more than one attempt - repeated events- , to study the effect of variables that change with time -time dependent covariates-, to analyze mutually exclusive decisions -competing risks- and to model behaviors that do not follow a normal distribution.

Fishways where trials were done are located in the Duero river basin. They are "technical" or "stepped" fish passes and more particularly: vertical slots and submerged notches with bottom orifice pool types.

The main results obtained were related to motivation and ascent of fish ladders (non-free and free trials) and location of fishway (free movement). Vertical slots were compared for the three species. For the barbel, it was been able to study their performance in the two pool types and to analyze the location of a fishway with two entrance branches. It was also analyzed the effect of 
different biotic (fish length) and abiotic variables (flow rate, water temperature, atmospheric pressure, water velocity) in fish behavior.

It was observed that these Iberian reophilic cyprinids have a similar ability to brown trout (contrary to common belief). As for the ascent time, different fishways did not show significant delays to upstream migration (approximately between 4 and 37 minutes for one meter height), having a significant effect the presence of turning pools in the design of the fish ladders (increasing the ascent time). Among pool types, barbel were faster in submerged notches with bottom orifice than in vertical slots. In designs with more than one entrance branch it was observed that they could increase the success rate of ascent. We had also found differences in the location of entrance branches depending on environmental variables like flow, water temperature and atmospheric pressure; but with different effects depending on the branch. The fish length analysis showed a significant effect for the vertical slots, where larger barbels ascended in less time.

This study is expected to serve as a methodological support in the development of future biological assessments and results will help for design of new fishways and / or improve existing ones. 


\section{INTRODUCCIÓN GENERAL}

\section{Los ríos y sus peces: el caso Ibérico}

Desde el inicio de la historia de la humanidad las personas han vivido en íntima unión con las fuentes y cursos de agua. El líquido elemento es fundamental para la vida, entre otras razones porque es el componente del que estamos mayormente formados. Son innumerables las civilizaciones desarrolladas a su alrededor y la actividad en su entorno. A su vez también son elementos vertebradores y de conexión del patrimonio natural, sirviendo de corredores verdes esenciales para el mantenimiento y desarrollo de multitud de especies de seres vivos. Los peces son uno de los grupos más representativos y que han atraído más la atención, tanto por ser un recurso alimenticio de importancia en muchos lugares desde hace milenios, así como por ser fuente de ocio y turismo en las últimas décadas. Desde el punto de vista ambiental son fundamentales en la cadena trófica, fuente importante de biodiversidad en estos ecosistemas y además se emplean como bioindicadores, siendo representativos de la calidad de las masas de agua en función de las especies que habitan los tramos, el estado y estructura de las poblaciones y su dinámica con el paso del tiempo.

Uno de los aspectos más destacables de una parte importante de la ictiofauna de agua dulce son sus desplazamientos o migraciones en busca de los mejores lugares de reproducción. Es bien sabido que muchas de las especies de peces se mueven a lo largo del río en función de la época del año para poder encontrar las condiciones más favorables para realizar la freza o desove. Esta generalidad, sin embargo, no es tan conocida para el caso de los peces Ibéricos. La mayoría del interés y los recursos han sido atraídos por especies con gran importancia comercial o de pesca deportiva y en zonas del centro y norte de Europa, así como Norteamérica (salmónidos principalmente). En el entorno Mediterráneo y más específicamente en la Península Ibérica, son varias las especies que realizan movimientos migratorios de mayor o menor entidad, pero de los cuales se desconocen muchos de los detalles al respecto. Según Sanz-Ronda et al. (2013), son aproximadamente el $65 \%$ los peces autóctonos que hacen estos desplazamientos, aumentando hasta un $80 \%$ en el caso de los endemismos (ver Figura 1 ). 

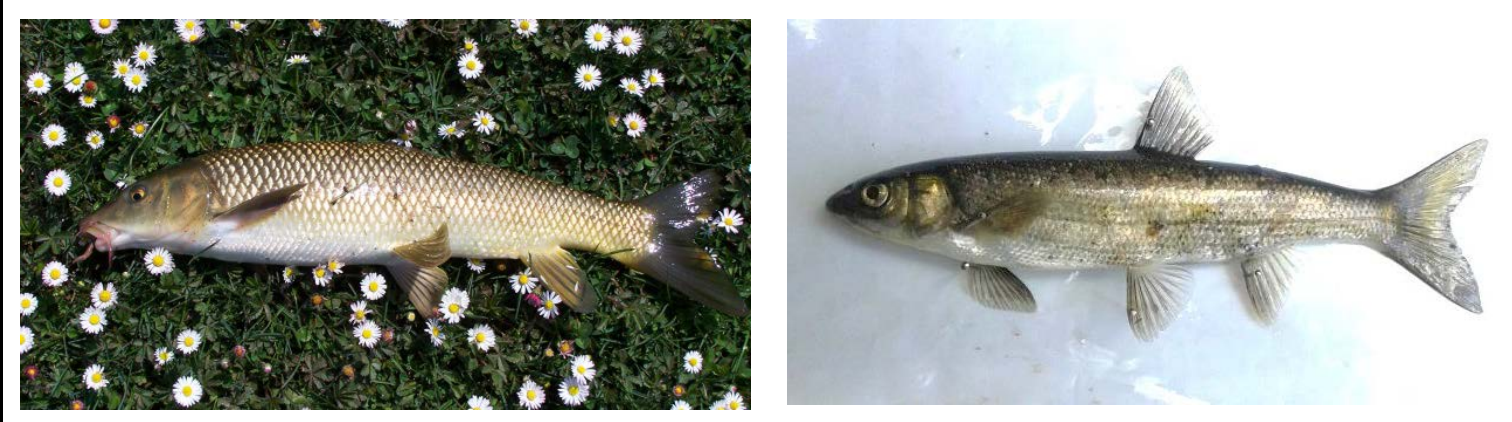

Figura 1. Ejemplos de endemismos Ibéricos que realizan movimientos migratorios de mayor o menor envergadura. Izq. Barbo común, Luciobarbus bocagei (Fuente: propia). Dcha. Boga del Duero, Pseudochondrostoma duriense (Fuente; dcha: Néstor González).

\section{Obstáculos y soluciones al libre movimiento de la ictiofauna}

A la hora de moverse por un curso de agua, los peces pueden encontrarse multitud de restricciones al mismo. Algunas son naturales, como por ejemplo las cascadas, siendo sin embargo las más frecuentes las de origen artificial. El efecto humano sobre el medio acuático es patente y son muchas las actuaciones sobre los cauces que pueden limitar o impedir la libertad de movimiento de la ictiofauna (ver Figura 2). Entre las más destacables y conocidas están las barreras físicas, como por ejemplo las presas o azudes, estaciones de aforo, cimentaciones que han sufrido descalces, etc. Además, tampoco se pueden olvidar las barreras comportamentales o etológicas como: oscuridad de tramos entubados, temperaturas de agua de desagües de fondo de grandes embalses, gradiente de velocidades prácticamente nulo en superficies embalsadas, etc.

Las afecciones generales sobre la ictiofauna de este tipo de problemas han sido bastante estudiadas y entre las más importantes podemos citar: la compartimentación del medio y sus poblaciones con las consiguientes pérdidas de diversidad y deriva genética, frezas en lugares poco adecuados y por tanto con menor viabilidad, colonización de espacios por especies exóticas, concentración de depredación y furtivismo. 


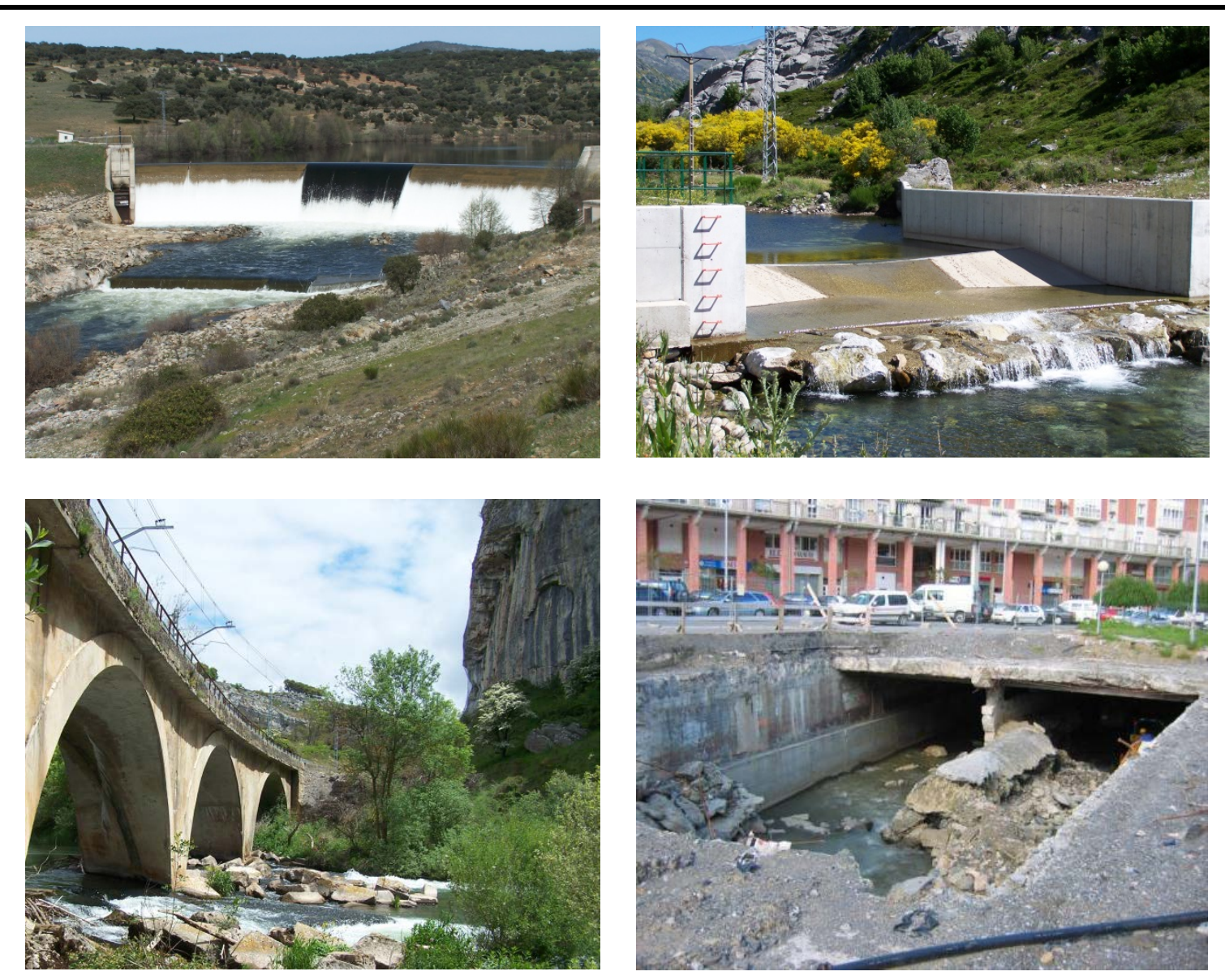

Figura 2. Ejemplos de obstáculos al libre movimiento de los peces. Arriba: izq. Presa; dcha. estación de aforo tipo V-flat. Abajo: izq. Descalce aguas abajo de cimentación de puente; dcha. oscuridad por río soterrado. (Fuente: propia)

Desde hace varios siglos, en la Península hubo muestras de sensibilidad y preocupación por la interrupción de los flujos migratorios de los peces. Aparece ya en documentos tan antiguos como el Liber ludiciorum (cuerpo de leyes visigodo del siglo VII d.C) en el que se hablaba de no interrumpir el paso en la totalidad de la anchura del río a los salmones que remontaban el mismo. En los últimos dos siglos, cuando más obras transversales se han ejecutado sobre los cauces y por tanto más compartimentación se ha hecho de los mismos, también han sido varias las leyes publicadas, de diferentes rangos y ámbitos (Ley de aguas de 1879, Ley de Pesca Fluvial de 1907 y 1942, Directiva Marco del Agua 2000/60/EC, Real Decreto 1290/2012 de modificación del Reglamento de Dominico Público Hidráulico, Ley 4/2015 de Patrimonio Natural de Castilla y león, Plan Hidrológico de la Demarcación Hidrográfica del Duero 2016-2021) que han hecho mención expresa a la problemática y a la obligación de buscar soluciones. Sin embargo, hasta la fecha todavía son una mayoría las infraestructuras que no cuentan con soluciones para evitarlo, o las 
mismas no funcionan de manera adecuada. Sirvan de ejemplo datos de la Confederación Hidrográfica del Duero, donde se ha hecho un esfuerzo por catalogar en los últimos años las presas y azudes y su afección, pudiendo estimarse de dichos datos (a falta de analizar otra serie de posibles obstáculos ya mencionados con anterioridad) que en torno al $25 \%$ de dichas obras son imposibles de remontar y más del 50\% no lo aseguran para toda la ictiofauna presente en el tramo (elaboración propia a partir de los datos de CHD, 2014).

En cuanto a las soluciones, las principales son la construcción de pasos para peces, aunque también existen otras relacionadas con la gestión (por ejemplo presas estacionales no coincidentes con épocas de migración), el transporte de peces (traslado desde aguas abajo hasta aguas arriba del obstáculo) y la demolición de obstáculos. En cuanto a los pasos o escalas para peces, es muy diversa la tipología y forma de funcionamiento, siendo las más comunes los escalas técnicas de artesas o estanques sucesivos (ver Figura 3), que son el objeto de la presente tesis. Se caracterizan por ser una consecución de estanques de agua con una pendiente determinada, salvando un desnivel total en base a pequeños saltos de agua entre estanques, los cuales idealmente cumplen con la condición de ser remontables por las especies de peces presentes o potenciales de dicho tramo.

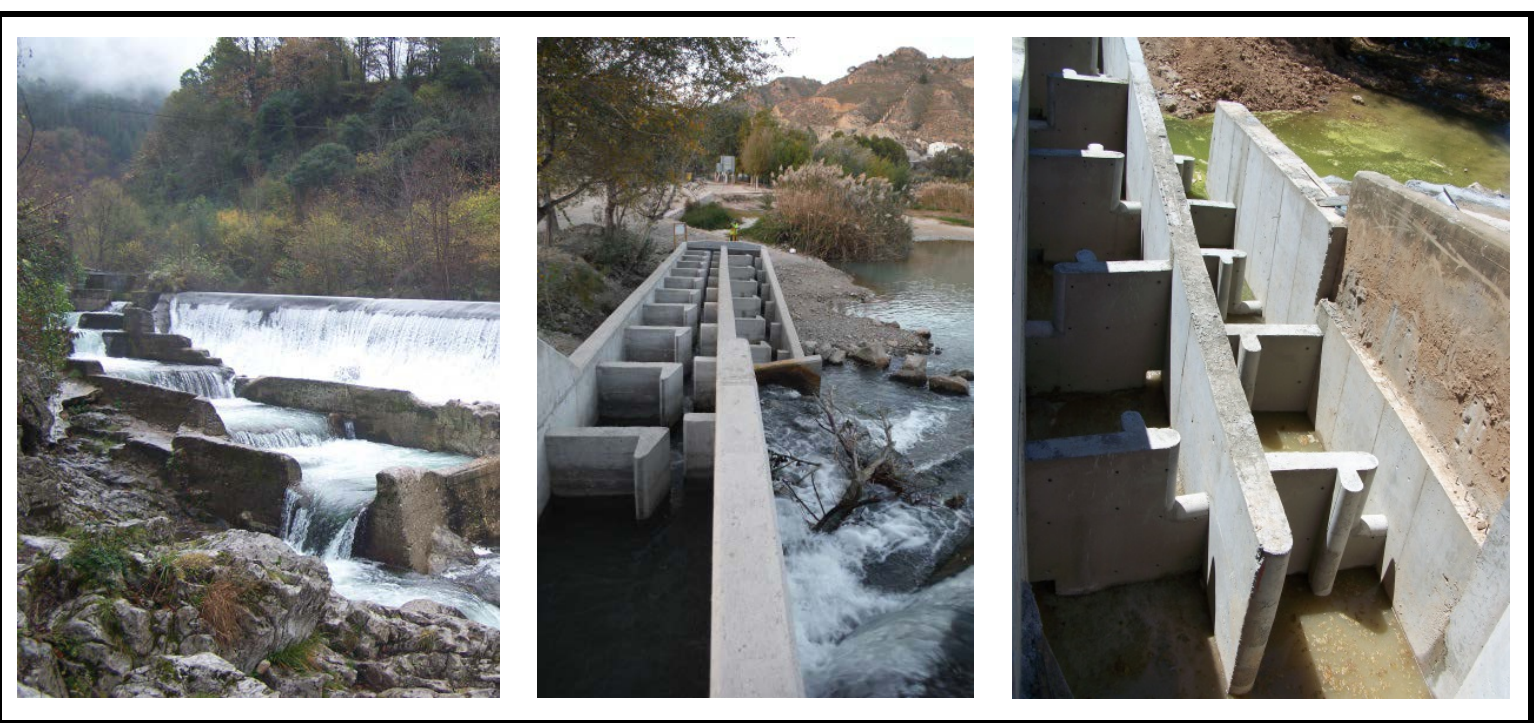

Figura 3. Ejemplos de tipologías de escalas de artesas o estanques sucesivos. Izq. Vertedero libre (río Sella, Asturias). Centro. Hendiduras verticales (río Segura, Murcia). Dcha. vertedero sumergido y orificio de fondo (río Duero, Valladolid). (Fuente: propia).

A la hora de diseñar y ejecutar este tipo de obras es muy importante seguir las recomendaciones testadas y propuestas por especialistas en el tema (Clay 1995; Martínez de Azagra 1999; Larinier 2002; FAO/DVWK 2002; Sanz-Ronda et al., 2013). En función de las especies de peces, del caudal 
circulante y de las condiciones topográficas, el diseño será uno u otro, y para su buen funcionamiento es fundamental cuidar al detalle todos estos parámetros. Debido a esta variedad de factores a tener en cuenta, así como la precisión necesaria a la hora de ser ejecutados, es frecuente que por diversos motivos las obras finalmente no funcionen de manera correcta. Por todo ello, se considera fundamental realizar una evaluación posterior para comprobar el buen funcionamiento (tanto a nivel hidráulico como biológico) y en caso contrario proponer las medidas necesarias para su mejora.

A nivel hidráulico, el estudio científico de escalas de artesas está muy desarrollado y son varias las publicaciones a fondo y de calidad al respecto (Rajaratnam et al., 1986, 1989; Larinier 2002; Bermudez et al., 2010; Silva et al. 2011; Fuentes-Pérez et al., 2014, 2016). Sin embargo, el vacío de información sobre el funcionamiento biológico de las escalas de artesas para las especies ibéricas es importante, especialmente en campo (en laboratorio sí se dispone de más estudios; véase por ej. Silva et al., 2009, 2012; Puertas et al., 2012; Santos et al., 2012; Alexandre et al., 2013; Branco et al., 2013).

\section{Evaluación biológica de pasos para peces}

Desde aproximadamente los años 80, en países del centro y norte de Europa y especialmente en Norteamérica, se incrementó el interés por conocer el comportamiento de los peces frente a los dispositivos de paso. De esos años surgen publicaciones tan relevantes en las posteriores décadas como la de Beach (1984); en la actualidad aún utilizada pero ya superada en muchos aspectos por otros estudios.

A grandes rasgos, las principales líneas de investigación han buscado por una parte ampliar el conocimiento relativo a la capacidad de nado de los peces, así como la influencia de las diferentes variables hidráulicas sobre éste. Por otra, realizar el seguimiento en el espacio y el tiempo de su movimiento en las escalas, así como su relación con variables bióticas y abióticas.

En todo este tiempo se han ido desarrollando diferentes tecnologías y metodologías de seguimiento adaptadas a los peces y el medio acuático. Entre las más utilizadas han estado el trampeo (butrones, redes de espera, redes activas), el vídeo-seguimiento, los contadores de peces (sónar, infrarrojos, laser), las marcas externas (elastómeros, anchor-tags, grapas, alpha-tags) y 
especialmente las marcas de envío y recepción de señales (radio-tags, PIT-tags, electromiogramas, dispositivos acústicos y satelitales) (ver Figura 4). Entre estas últimas, la que ha tenido mayor implantación han sido los PIT-tags, en muchas ocasiones combinados con alguna otra. Entre las razones de su popularidad están las siguientes: proporciona un dato único identificativo del pez junto con la hora y lugar de paso al atravesar una antena, el precio por marca es mucho menor que el resto, no necesita de batería para su funcionamiento, los daños que provoca al pez (con una buena elección del tamaño de la marca) son prácticamente nulos, la retención y duración con el paso del tiempo es muy elevada y tiene una gran versatilidad a la hora de diseñar la red de seguimiento.

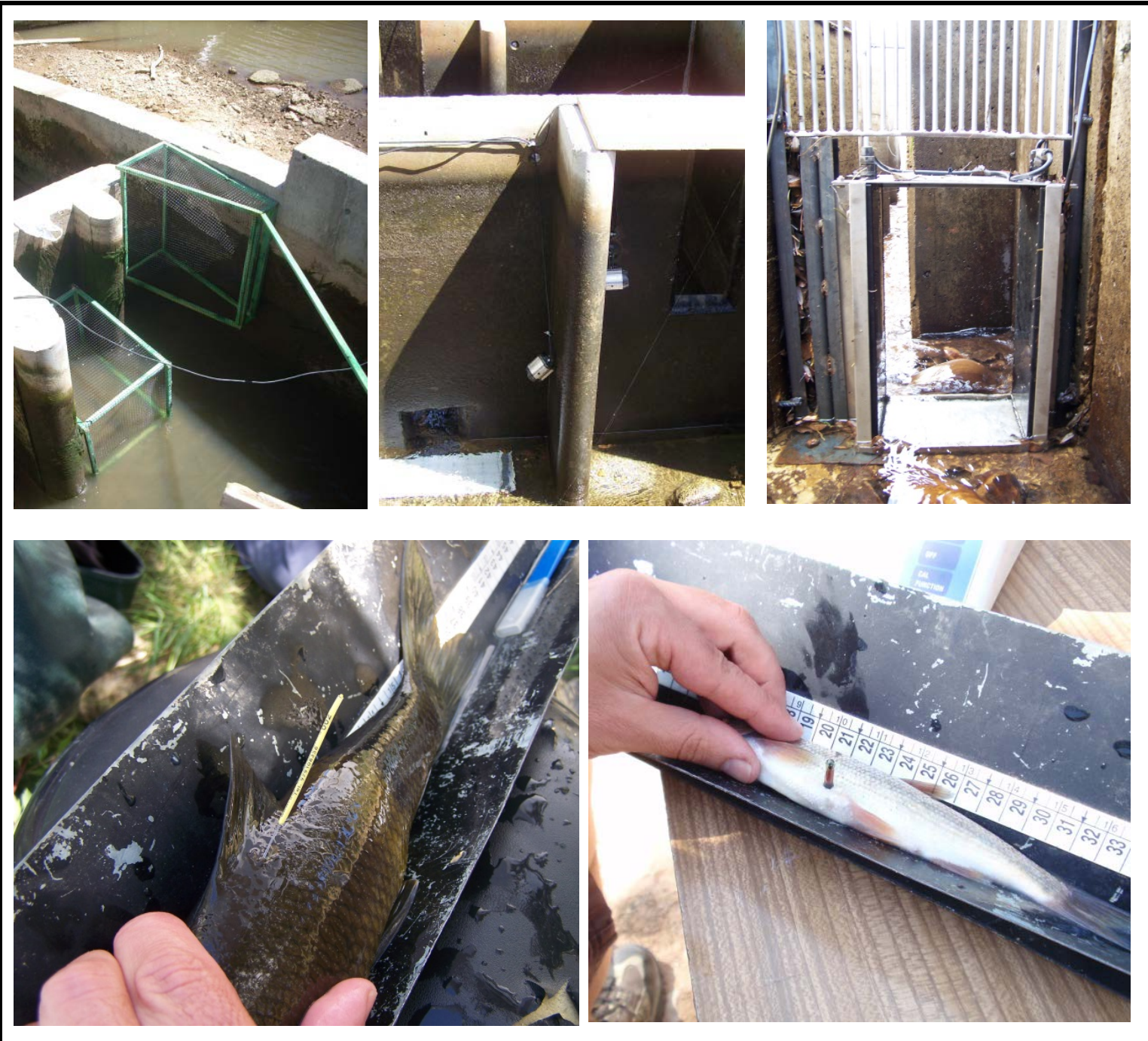

Figura 4. Tecnologías para el seguimiento de peces. Arriba: izq. Trampeo con butrones; centro: vídeo-seguimiento; dcha. contador de peces. Abajo: izq. Marcaje con Anchor-tag; dcha. marcaje con PIT-tag. (Fuente: propia). 
En el ámbito Ibérico, las evaluaciones biológicas en campo externas al grupo de investigación al que pertenece el presente doctorando (GEA-Ecohidráulica) y llevadas a cabo en escalas de artesas son recientes y escasas, especialmente para el número de obras existentes (escala en el río Oiartzun: DFG, 2005; escala en el río Urola: DFG, 2006; escala en el río Araxes: DFG, 2008; escala en el río Xerta: URS, 2010; escala en el río Cinca: Rocaspana et al., 2012; escala en el río Mondego: Cardoso, 2015). Además la mayoría de estos estudios, a excepción del último, son trabajos de índole técnica y no científica. No abordan una comparación entre especies y/o diseños, ni la relación en profundidad del comportamiento con otras variables ambientales. Además el formato no favorece una divulgación del conocimiento generado y por tanto su repercusión. Todo ello supone un interés añadido para llevar a cabo la presente tesis con la estructura aquí presentada.

Por todo lo expuesto, este trabajo se ha centrado en la obtención de resultados en campo relativos al comportamiento de algunas de las principales especies piscícolas Ibéricas en escalas de peces y su relación con diferentes variables. Se han buscado condiciones de experimentación lo más semejantes a la realidad y la metodología tanto de ensayo como de análisis de datos más adecuada para ello, con el objetivo final de mejorar el conocimiento al respecto, difundirlo y aplicarlo en la mejora de los pasos actuales y en los diseños futuros. 


\section{OBJETIVOS}

\section{Objetivo general}

Conocer el funcionamiento de escalas de peces de artesas para algunas de las principales especies migradoras de la Península Ibérica, que repercutan en la mejora de la ingeniería de las mismas.

\section{Objetivos específicos}

- Revisar el estado del arte relativo a la evaluación biológica de obstáculos y/o soluciones a la migración de ascenso de peces.

- Comparar algunas de las principales especies de peces Ibéricos en su movimiento migratorio de ascenso a través de escalas de artesas, así como las principales tipologías de éstas.

- Aumentar el conocimiento en este ámbito sobre los ciprínidos Ibéricos.

- Relacionar variables bióticas y abióticas con el comportamiento migratorio de ascenso de los peces.

- Obtener conclusiones que repercutan de manera práctica en el mejor diseño de soluciones a la migración de los peces en la Península Ibérica.

- Desarrollar una metodología de evaluación apta para las características de ríos y peces Ibéricos.

- Investigar en el tratamiento de datos con técnicas estadísticas adecuadas y adaptadas a las peculiaridades del comportamiento de la ictiofauna en sus movimientos migratorios. 


\section{METODOLOGÍA}

\section{Zona de estudio}

El área preferente de trabajo se ha circunscrito a la Demarcación o Cuenca Hidrográfica del Duero (Noroeste de la Península Ibérica, ver Figura 5). La elección ha respondido a diversos criterios considerados relevantes a la hora de llevar a cabo trabajos similares, entre los que se encuentran:

- Territorio con una cantidad importante de obstáculos a la migración de peces y soluciones al respecto de diferentes tipologías.

- Conocimiento a fondo de varios de los proyectos de diseño de pasos para peces por haber participado en su redacción/ejecución.

- Presencia de las principales familias de ictiofauna Ibérica (Salmónidos y Ciprínidos), así como alguno de sus principales representantes en lo referente a movimientos migratorios (Trucha común - Salmo trutta -, Barbo ibérico - Luciobarbus bocagei - y boga del Duero Pseudochondrostoma duriense-).

- Proximidad: los estudios de campo en este ámbito tienen una relativa complejidad, lo que requiere de una atención lo más continua y cercana posible.

- Buena relación con administraciones y propietarios/as: son varios los trámites administrativos (universidad, organismos de gestión de aguas y del medio natural, guardería forestal, fuerzas del orden) necesarios para llevar a cabo estos estudios bajo el amparo legal y una cierta protección. Además, es muy importante contar con la colaboración de la propiedad de las escalas de peces ya que en último término los trabajos se ejecutan en su terreno y es necesario el entendimiento entre ambas partes.

- Presencia de compuertas de regulación en las escalas de peces: es fundamental para el control de las condiciones hidráulicas y las labores de instalación y mantenimiento.

En concreto, los emplazamientos elegidos han sido:

- Escalas de hendiduras verticales: en la presa de abastecimiento de la piscifactoría de trucha común de la Junta de Castilla y León en el río Porma (Término Municipal (T.M.) de Vegas del Condado, León) y en la presa de derivación para aprovechamiento hidroeléctrico de propiedad privada en el río Duero (T.M. de Vadocondes, Burgos). 
- Escalas de vertederos sumergidos y orificio de fondo: Presas de derivación de aprovechamiento hidroeléctrico de propiedad privada en el río Duero (T.M. de Guma, Burgos; T.M. de Peñafiel, Valladolid).

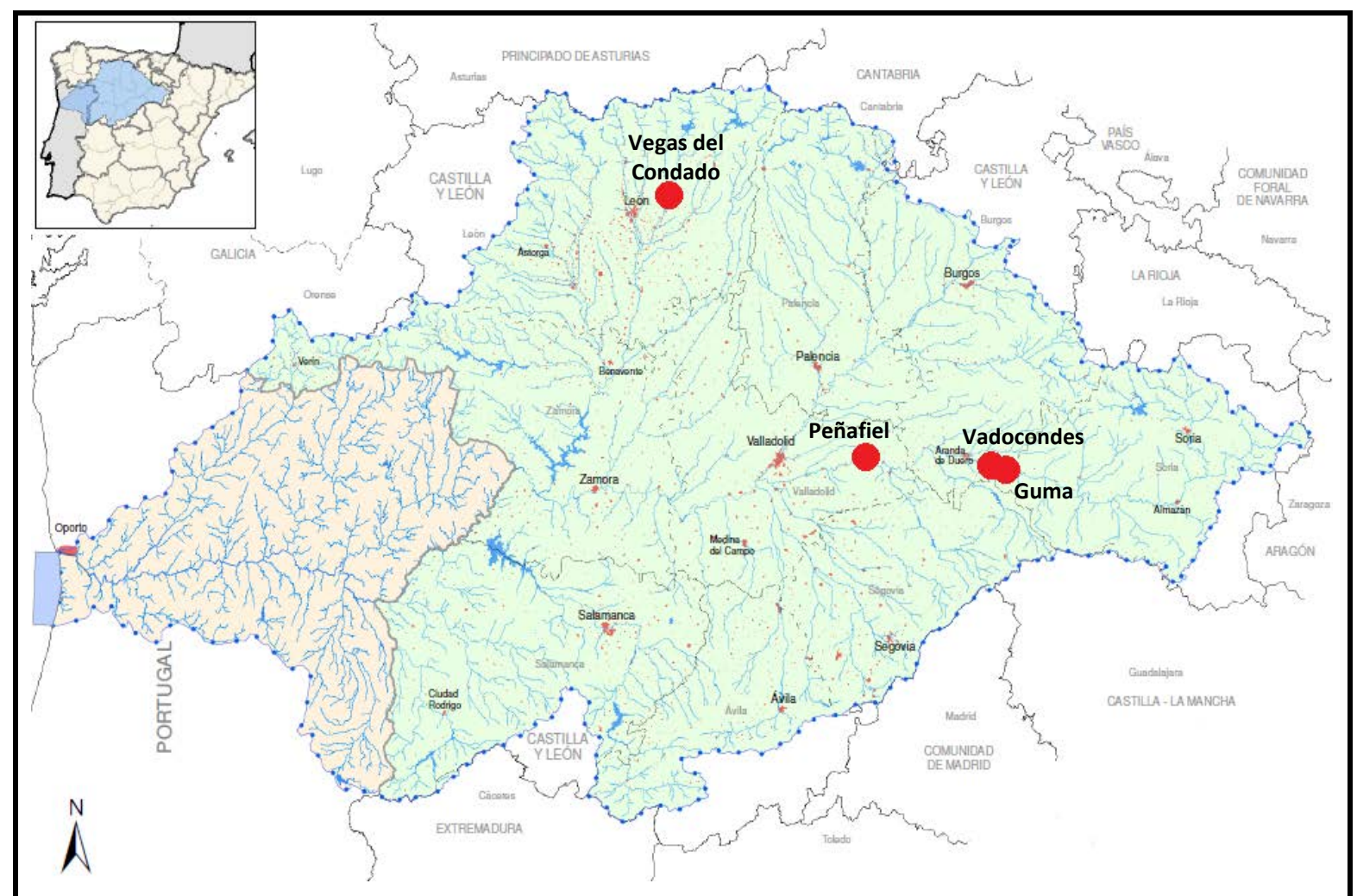

Figura 5. Mapa de localización de la zona de estudio. Sombreado en azul aparece delimitada la cuenca del Duero. Los círculos rojos indican los lugares de experimentación (para más detalles consultar capítulos I,II y III) (elaborado a partir de CHD, 2014).

\section{Escallas de peces}

Los pasos para peces utilizados como laboratorios de experimentación en la presente tesis han sido cuatro, situados en los respectivos azudes indicados con anterioridad. Todos pertenecen a la categoría de escalas de artesas o estanques sucesivos, dos de ellos de tipología hendidura vertical y los otros dos de vertederos sumergidos con orificio de fondo (ver Figura 6). La variedad en este tipo de soluciones es muy grande y por tanto inabarcable en su totalidad por este trabajo. Por eso se han escogido las más habituales, pero de las cuales y, especialmente para los ciprínidos ibéricos, no hay datos relativos a su funcionamiento en campo. 


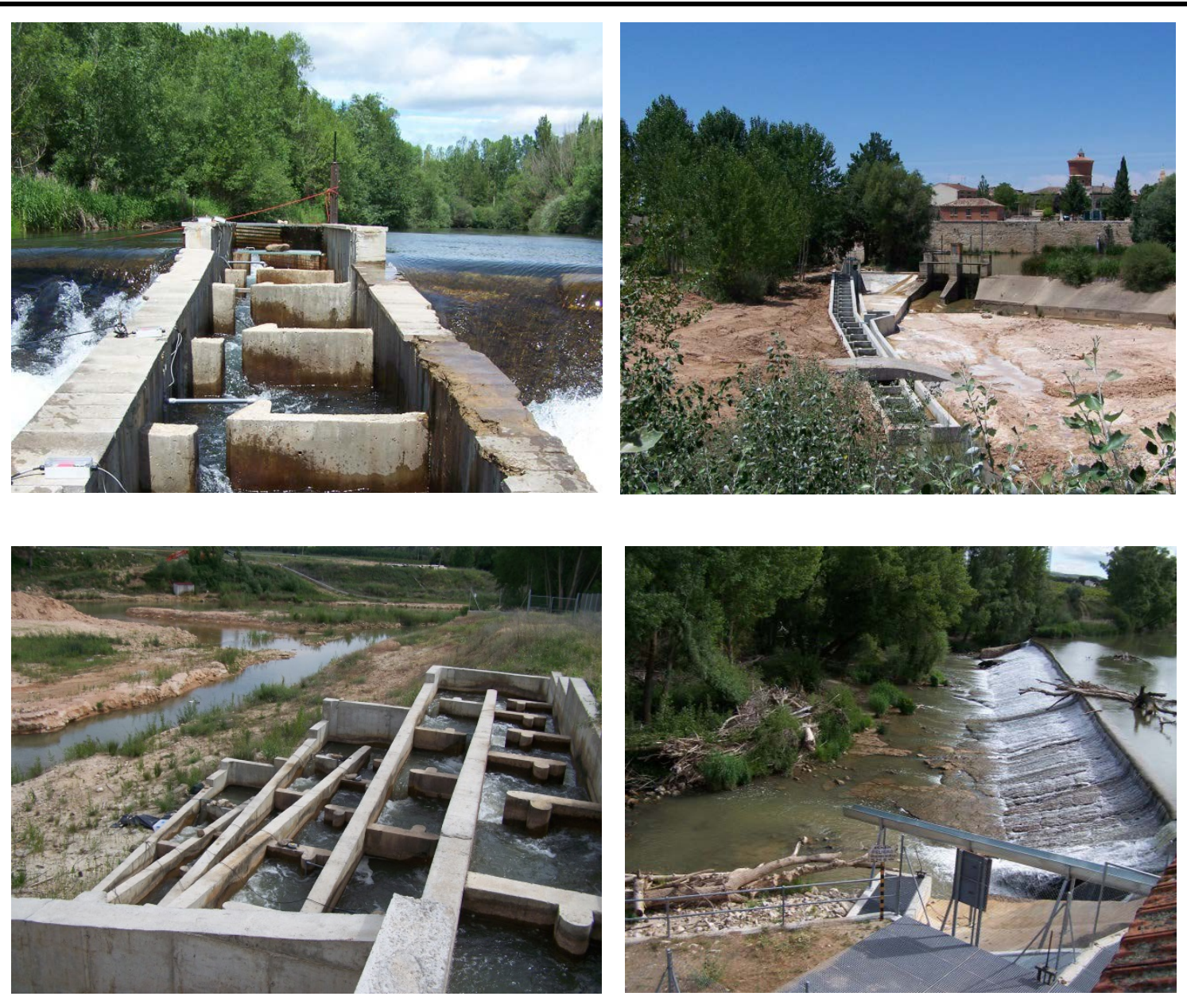

Figura 6. Escalas de artesas utilizadas para los ensayos en campo de la presente tesis. Arriba: tipología Hendiduras verticales (izq. Vegas del Condado; Dcha. Vadocondes). Debajo: tipología vertederos sumergidos con orificios de fondo (Izq. Guma; dcha. Peñafiel).

Hay que destacar además que la escala situada en Peñafiel tiene una particularidad que la hizo del interés de este trabajo y es que cuenta con dos brazos de entrada de peces. Tiene un diseño tal que los peces pueden acceder al paso, ya sea a través del canal de desagüe de las turbinas o desde la zona situada a los pies de la presa. Es una solución innovadora en la Península con un potencial teórico de aplicabilidad bastante alto debido a la configuración de las centrales hidroeléctricas, especialmente en cuencas como la del Duero. En este tipo de instalaciones es frecuente que las turbinas estén a la altura de la misma presa y cuenten con un canal de restitución que conduce la mayor cantidad de caudal lejos de la base del azud. Además, el caudal vertido por coronación supone un pequeño porcentaje del agua que circula por el río.

Todas las escalas fueron caracterizadas a nivel topográfico en detalle para conocer sus características principales y así poder relacionarlas con el movimiento de los peces: 
- Dimensiones de los estanques

- Pendiente

- Dimensiones de los vertederos

- Desniveles entre estanques

Además también fueron analizadas a nivel hidráulico:

- Desnivel de agua entre aguas arriba y abajo del obstáculo

- Profundidad de agua en los estanques

- Salto de agua entre estanques

- Caudal circulante por la escala

- Potencia o energía disipada en los estanques

- Velocidades máximas del agua

\section{Muestra de peces}

En el global de los estudios realizados, se trabajó con un salmónido (trucha común, Salmo trutta) y dos ciprínidos endémicos de la Península Ibérica (barbo Ibérico, Luciobarbus bocagei y boga del Duero, Pseudochondrostoma duriense). Todos ellos fueron elegidos por varios motivos:

- Importancia biológica e interés de conservación: tanto la trucha como la boga están declaradas especies vulnerables y las tres son relevantes en el funcionamiento de los ecosistemas que ocupan.

- Importancia socioeconómica: son especies de gran interés para la pesca deportiva, especialmente la trucha, en los últimos tiempos el barbo y locamente la boga.

- Presencia en la zona de interés: en la cuenca del Duero son los principales representantes de peces potamodromos autóctonos y por tanto habitualmente las especies objetivo a la hora de diseñar las escalas.

- Tamaño adecuado para la experimentación: los rangos de tamaño de estas especies una vez que alcanzan la madurez sexual (óptimo para estudios de migración) permiten llevar a cabo ensayos con marcaje interno de los mismos sin causarles ningún daño (más detalles en el siguiente apartado).

- Escasez de información: se consideraron especies de interés debido a la falta de información rigurosa en campo, especialmente para los ciprínidos Ibéricos. Además se 
consideró importante estudiar las similitudes/diferencias entre estos y la trucha, los cuales cohabitan en muchos de los tramos de la cuenca Duero.

Para obtener las diferentes muestras de peces, las técnicas más habituales han sido la pesca eléctrica (zonas vadeables y desde embarcación) y el trampeo en las propias escalas. Esta elección ha respondido a los siguientes condicionantes:

- Zonas de río vadeables y con presencia de peces: en estos casos se ha utilizado la pesca eléctrica manual, en equipos de entre 4 y 5 personas. En zonas no vadeables se ha utilizado embarcación en casos puntuales, teniendo en cuenta que el presupuesto aumenta notablemente y la efectividad en la captura no es muy alta en aguas con profundidades mayores a $2,5 \mathrm{~m}$.

- Interés en conseguir muestras con comportamiento migratorio patente: en estos casos se han capturado peces mediante trampas en las escalas de peces.

- Sensibilidad/estrés sufridos por los diferentes tipos de captura.

Una vez capturados los peces, se han mantenido en estanques de estabulación sobre el propio río o en depósitos de agua con oxigenación hasta su recuperación y marcaje. La manipulación ha seguido las recomendaciones éticas y legales dictaminadas por la Unión Europea (Council, 1986).

\section{Marcaje y seguimiento}

Para conocer el comportamiento de los peces en las escalas de peces es necesario contar con dispositivos/técnicas que nos proporcionen datos relativos a sus movimientos (en el espacio y en el tiempo). En los últimos años se ha generalizado el uso de la tecnología PIT-tag con este fin (más detalles en Capítulos I, II y III; apartado "Methods") y por tanto ha sido la escogida para los trabajos aquí presentados. Algunas de las razones de su interés son:

- Transmisores pasivos: microchip instalable en cada individuo que no requiere de una batería para su funcionamiento. Esto hace que su vida útil pueda ser ilimitada si el chip no sufre desperfectos.

- Tamaño de transmisores: en la actualidad hay disponibles tamaños que van desde los 8 $\mathrm{mm}$ de longitud y pesos inferiores a 0,1 g, permitiendo marcar peces de longitudes 
superiores a los 60-70 $\mathrm{mm}$ sin verse prácticamente afectada la supervivencia de los mismos.

- Economía: sistema relativamente barato, especialmente en cuanto a los transmisores utilizados (entre 1,5-4€ por chip) y en comparación con otros métodos de seguimiento.

- Información espacio-temporal: proporcionan hora, antena de paso y numeración del pez.

- Tasas de lectura de las antenas: muy buenas, especialmente para lugares de paso de dimensiones reducidas (como es el caso de los vertederos de las escalas de peces).

- Adaptabilidad del sistema: se adecúa a diferentes circunstancias (número de antenas, tamaño de antenas, tipo de lecturas, tamaño de los transmisores).

En la puesta en práctica en campo de esta tecnología cabe mencionar varios aspectos a tener en cuenta:

- Necesidad de una fuente de energía para el equipo de emisión y recepción de señales de las antenas.

- Evitar lugares donde el ruido electromagnético sea elevado (lámparas fluorescentes, cargadores de ordenador, motores o máquinas con bobinado, cableado de media-alta tensión cercano).

- Antenas localizadas en lugares donde el paso de peces sea lo más estrecho posible.

- Riesgo de vandalismo.

- Evitar zonas donde se alcancen temperaturas muy elevadas y si es el caso proteger o ventilar los equipos.

- Accesibilidad de la instalación para poder llevar a cabo todas las operaciones de calibración y mantenimiento.

- $\quad$ Anclaje firme de las antenas.

Para realizar el proceso de marcaje, los individuos fueron mantenidos en tanques de agua oxigenados y sedados con anestésico MS-222 (dosis de 0,20 g/L). Una vez introducido el transmisor (cavidad intraperitoneal mediante incisión con bisturí), los peces eran estabulados en estanques de reposo también oxigenados, pero en este caso sin anestesia. Una vez recuperados (posición del cuerpo en equilibrio, apertura-cierre de agallas normal, reacción a estímulos) los individuos fueron liberados en la zona de experimentación. 
Es fundamental en este punto compartir las reflexiones recientemente expuestas por Cooke et al., (2015), referentes a la experimentación con peces en campo y los protocolos de cuidado a seguir. En dicho trabajo comenta como no se pueden olvidar ciertas diferencias respecto a la experimentación en laboratorio:

- Contamos con una diversidad enorme inter e intraespecífica.

- Son animales salvajes y se comportan como tal.

- El trabajo en campo es necesariamente adaptable a circunstancias cambiantes.

- La captura, el manejo y la experimentación suele estar muy influenciada por aspectos logísticos como los accesos, caudales circulantes, meteorología, riesgo de robos, fuentes de energía, etc.

- La anestesia y analgesia no funcionan por igual y sus efectos pueden no ser positivos en todos los casos.

\section{Análisis de datos}

Lo primero a tener en cuenta a la hora de obtener resultados de comportamiento de peces en escalas es definir los movimientos que nos interesan. En este trabajo la medida principal o de base para ello ha sido el "intento". Se define como aquel movimiento que podemos asociar claramente con el ascenso. Para ello, lo más habitual es considerar no solo la localización de la escala (en experimentos libres, ver Resultados III) o el paso por la primera antena (experimentos estabulados, ver Resultados I y II), sino que es necesario confirmar el ascenso por una segunda antena. Con ello se pretende evitar el ruido que pueden provocar otro tipo de movimientos como los de reconocimientos del entorno, refugio o alimentación. De esta forma, tendremos definidos y diferenciados los eventos de ascenso y así podremos asociar a cada evento unos datos morfométricos del pez, el momento en que se ha producido, el tiempo que ha durado dicho evento, si ha tenido éxito en el ascenso, las condiciones bióticas y abióticas que lo acompañan, etc.

En base a esta información, los resultados de mayor interés en los estudios realizados son los siguientes (en función del trabajo específico se escogerán unos u otros): 
- Motivación: hace referencia al impulso/deseo que tienen los peces por realizar movimientos. Algunas de las medidas habituales son:

$>\quad$ Número de intentos: cantidad de movimientos de ascenso que realiza el pez.

$>$ Tiempo hasta el primer intento: tiempo que pasa desde que comienza el experimento hasta que el individuo decide moverse.

$>$ Tiempo entre intentos: tiempo que pasa entre cada intento.

> Localización: zona de paso en experimentos donde los peces pueden acceder por más de un lugar (Resultados III).

- Ascenso: se refiere a cómo realiza el pez su movimiento de superación de la escala, midiéndolo habitualmente como:

$>$ Éxito en el ascenso: proporción de individuos que logran ascender el desnivel en estudio.

$>$ Tiempo de ascenso: tiempo que tardan en superar un determinado desnivel. Habitualmente este tiempo lo referiremos a un metro de desnivel, facilitando así la comparación análoga entre diferentes escalas.

$>$ Desnivel superado: proporción de peces que alcanza una determinada altura.

A la hora de analizar estadísticamente todos estos resultados hay que tener en cuenta una serie de particularidades:

- Lo más habitual es que se obtengan resultados del momento en que se producen los eventos de interés a lo largo de una línea temporal (ya sea en horas, días, meses, etc).

- $\quad$ Los resultados no siguen una distribución normal, estadísticamente hablando.

- No todos los individuos participan en los experimentos (peces que no tienen ningún intento).

- $\quad$ No todos los individuos tienen porqué comenzar el experimento en el mismo momento.

- Hay individuos que pueden realizar más de un intento de ascenso.

- Lo habitual es que la respuesta sea dicotómica (por ejemplo Sí/No realizan intento), pero en ocasiones pueden producirse variaciones, cómo en el caso de escalas con más de una entrada de peces, donde el resultado puede ser "No entra", "Sí entra por un brazo" o "Sí entra por el otro brazo", existiendo una clara competencia entre estos últimos, ya que si 
se da una de las dos respuestas positivas desaparece la posibilidad de que acontezca la otra.

- En muchas ocasiones resulta de interés estudiar las relaciones entre las variables ambientales y el comportamiento de los peces, siendo los valores de éstas cambiantes a lo largo de la línea temporal de seguimiento (por ejemplo la temperatura, la presión atmosférica, el caudal, etc.).

Para poder resolver las situaciones anteriores, las cuales para la estadística convencional suponen problemas o dificultades importantes, tenemos las técnicas englobadas dentro de la "estadística o análisis de Supervivencia" (Hosmer et al., 2008, Allison 2010, Castro-Santos 2012, Kleinbaum and Klein, 2012), desarrollada ampliamente en campos como la medicina, la resistencia de materiales y actualmente mostrándose con gran potencial de uso en aspectos biológicos relacionados con variables a lo largo de una línea temporal.

Dichas técnicas estadísticas cuentan con las siguientes herramientas para resolver las particularidades antes expuestas:

- La base de estas técnicas es el acontecimiento o evento que se produce a lo largo de una línea temporal.

- No es necesaria una distribución normal de los datos.

- Todos aquellos individuos que no participan en el experimento durante el tiempo que dura éste (no tienen evento) pueden incluirse a través de la herramienta de censura de los mismos. Esto nos permite asignarlos un peso relativo en el análisis entendiendo que, aunque no hayan participado hasta el momento, si el experimento tuviese una duración infinita probablemente sí lo harían.

- En aquellos casos en los que los individuos entran al experimento en diferentes momentos podemos utilizar dos recursos: asignar a cada uno una línea relativa de tiempo en el que el momento de entrada es el momento 0 (cuando las covariables no cambian a lo largo del tiempo), o utilizar las herramientas de recuento o "counting process" con las que podemos asignar unas fechas de inicio y fin (covariables que cambian con el paso del tiempo). 
- Si queremos analizar resultados relativos a varios intentos por pez, hay que tener en cuenta que éstos no son independientes entre sí. Para ello contamos con las herramientas de eventos recurrentes.

- En aquellos casos en los que la respuesta no es dicotómica y hay competencia entre alguna de ellas, tenemos las herramientas de riesgos competitivos.

- Cuando queramos saber la influencia de variables que cambian con el tiempo, tendremos las herramientas de variables dependientes del tiempo.

- Para aquellos casos en los que, además de conocer la influencia de ciertas variables y compararlas, queremos modelizar dicho efecto, contamos con una gran variedad de recursos para ello, pudiendo utilizar tanto modelos no paramétricos (conocidos como tablas de vida o Kaplan-Meier), semi-paramétricos (riesgos proporcionales o Cox) y paramétricos (en base a las principales distribuciones de probabilidad: Weibull, Gamma, Logística, Log-logística, exponencial, etc). 


\section{RESULTADOS I: Ascent ability of Brown trout, Salmo trutta, and two \\ Iberian cyprinids -Iberian barbel, Luciobarbus bocagei, and Northern straight-mouth nase, Pseudochondrostoma duriense- in a vertical slot fishway.}
Francisco Javier SANZ-RONDA*1, Francisco Javier BRAVO-CÓRDOBA ${ }^{1}$, Juan Francisco FUENTES- PÉREZ ${ }^{1}$, Theodore CASTRO-SANTOS ${ }^{2}$

Publicado en Knowledge and Management of Aquatic Ecosystems

${ }^{1}$ U. D. de Hidráulica e Hidrología.

Grupo de Ecohidráulica Aplicada (GEA-ecohidraulica.org)

Departamento de Ingeniería Agrícola y Forestal.

E.T.S.II.AA. Universidad de Valladolid.

Avda. Madrid, 44; 34004 Palencia (Spain)

+34 979108358 (Ph.)

+34 979108302 (Fax)

jsanz@iaf.uva.es

${ }^{2}$ S.O. Conte Anadromous Fish Research Center, USGS-Leetown Science Center

P.O. Box 796, One Migratory Way

Turners Falls, MA 01376 


\begin{abstract}
Passage performance of brown trout (Salmo trutta), Iberian barbel (Luciobarbus bocagei), and northern straight-mouth nase (Pseudochondrostoma duriense) was investigated in a vertical slot fishway in the Porma River (Duero River basin, Spain) using PIT technology. We analysed the effects of different fishway discharges on motivation and passage success. Both cyprinid species ascended the fishway easily, performing better than the trout despite their theoretically weaker swimming performance. Fishway discharge affected fish motivation although it did not influence clearly on passage success. Observed results can guide in the design criteria of vertical slot fishways for native fish.
\end{abstract}

Keywords: Iberian fish / vertical slot fishway / fish passage / motivation / transit time

\title{
Introduction
}

The potamodromous fish fauna of the Iberian Peninsula is mostly composed of endemic rheophylic cyprinids. Most common among these are mainly Iberian barbel (Luciobarbus bocagei Steindachner, herafter referred to as 'barbel'), and Northern straight-mouth nase (Pseudochondrostoma duriense Coelho; hereafter referred to as 'nase') and their close relatives (Doadrio, 2001). They occupy a range of riverine habitats, from floodplains to headwaters and often co-occur with brown trout (Salmo trutta L.). Like many cyprinids, barbel and nase usually ascend to headwaters to spawn in spring.

In Iberia, many cyprinids are local endemics and have IUCN (International Union for Conservation of Nature) protection status. Iberian barbel is listed as "least concern"; nase is more threatened, being categorized as "vulnerable" and it is mentioned on Annex II of the European Union Habitats Directive (92/43/EEC). Barriers to movement block access to essential habitat and are among the principal threats affecting these communities (Doadrio et al., 2011).

Fishway design recommendations usually distinguish between salmonids and a large group of fish, often called "others", "non salmonids" or "weak swimmers", "white fish", or "coarse fish" (Alexandre et al., 2013; Mallen-Cooper, 1999; Mateus et al., 2008).

Fish passes for salmonids are designed with higher slope or drop than for other fish (Larinier, 2002 (a)). This is because salmonids are widely assumed to be comparatively strong and motivated 
swimmers. This assumption is founded on very few data, however, and recent studies suggest that other freshwater species may be as strong or stronger swimmers than salmonids (Castro-Santos, 2005; Pompeu and Martinez 2007; Castro-Santos et al., 2013; Sanz-Ronda et al., 2015).

One of the most popular fishway designs in Spain is the vertical slot fishway. The design was originally developed for salmonid passage, but is increasingly favored for a variety of species, including cyprinids (Sanz-Ronda et al., 2010).

Vertical slot fishways were initially designed to accommodate large fluctuations in water level while maintaining constant such hydraulic factors as energy dissipation rate and velocity (Rajaratnam et al., 1986; Larinier, 2002 (b); Rodríguez et al., 2006; Wang et al., 2010). They have other advantages, though, notably that the slots offer passage opportunities throughout the water column, and are thought to be compatible with a broad range of species (Stuart and Berghuis, 2002; Mallen-Cooper and Brand, 2007; White et al., 2010).

Recent compilations of passage performance, however, have raised serious questions about the effectiveness of the design, with performance ranging from near $0 \%$ to near $100 \%$ efficiency (Bunt et al., 2011; Noonan et al., 2012).

The reason for this variation in performance is poorly understood, and there is a need for rigorous biological evaluation of fish ladders if hydraulic designs are to be improved (Castro-Santos et al., 2009; Bunt et al., 2011; Cooke and Hinch, 2013).

Recent efforts to establish standardized passage metrics based on movement theory have yet to be widely adopted (Castro-Santos et al., 2009; Castro-Santos and Haro, 2010; Castro-Santos and Perry, 2012; Cooke and Hinch, 2013). By explicitly measuring rates of movement and failure as fish approach, enter, and passage numerous fishways of various designs it will become possible to better understand why and to what extent some fishways perform better than others (Travade and Larinier, 2002 (b); Bunt et al., 2011).

In the case of passage performance, it depends on the interactions between the structural and hydraulic features of each fishway, fish behavior, and swimming ability (Makrakis et al., 2010). Behavior and swimming performance are in turn affected by environmental parameters like temperature, turbidity, dissolved oxygen, etc. and biological parameters like species, age, sex or physiological status (James and Johnston, 1998; Plaut, 2002; Clough et al., 2004; Pedersen et al., 2008). 
There are few published studies of passage performance of Iberian fishes. Most of the existing work was performed in laboratory settings and focused on the hydraulic preferences of fish within pool-type fish ladders (Silva et al., 2009; Silva et al., 2012; Branco et al., 2013).

The relevance of these data to field conditions is not well-established, however, and more work is needed to verify the principles learned in the laboratory (Thiem et al., 2013).

The purpose of this paper is to evaluate the passage performance of native brown trout, lberian barbel and northern straight-mouth nase ascending a vertical slot fishway in field conditions and under different flow regimes.

\section{Methods}

\section{Study site:}

The experiments were carried out in the Porma River (part of the Duero River watershed), in the village of Vegas del Condado, (province of León in Northwest Spain; 42 41' 17.40 "N; 5²1' 27.26" W; Figure 1). The river drains a watershed of $1146 \mathrm{~km}^{2}$ with mean annual discharge of about 25 $\mathrm{m}^{3} / \mathrm{s}$. It is strongly regulated for irrigation and during spring and summer discharge is higher and water temperature is lower than in natural conditions.

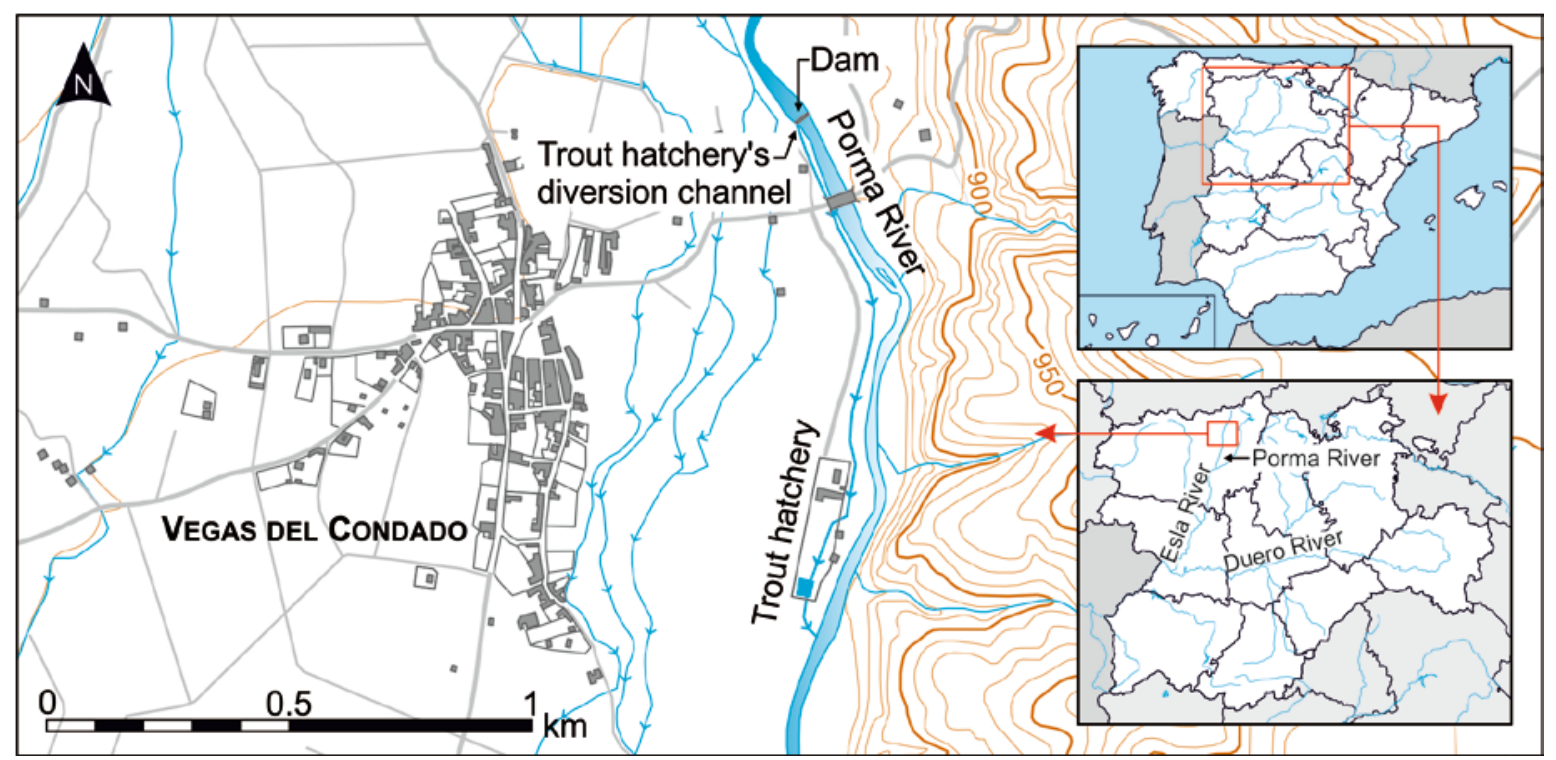

Fig. 1. Study site location: Porma River, Castilla y León region (Northwest Spain). 
The reach under study belongs to the metarhitron area with an average altitude of about 860 meters above sea level. The zone corresponds to a C4 category (gravel-bed stream of moderate sinuosity with a slope of 0.001-0.02 m/m; (Rosgen and Silvey, 1996), and the most abundant fish species are brown trout, Iberian barbel, northern straight-mouth nase and Northern Iberian chub (Squalius carolitertii Doadrio), all of them native and potamodromous fish.

In 1986 a gravity dam ( $1.80 \mathrm{~m}$ high by $35 \mathrm{~m}$ wide) was built. To mitigate the habitat fragmentation caused by the dam, a straight vertical-slot fishway was built in 2009 on the right bank of the dam (Figure 2). The length of the fish ladder is $24 \mathrm{~m}$ with a mean slope of 7.7\% (range: $7.1 \%-9.4 \%$ ). The design flow is $0.350 \mathrm{~m}^{3} / \mathrm{s}$, with 9 pools of $2.4 \mathrm{~m}$ long $\times 1.6 \mathrm{~m}$ wide and an average water depth of $1.1 \mathrm{~m}$. The drop between pools is $0.2 \mathrm{~m}$. The width of the slots is $0.2 \mathrm{~m}$ and the water velocity through them is variable depending on the flow and the local bottom slope (Table II). The volumetric energy dissipated is between 180 and $190 \mathrm{~W} / \mathrm{m}^{3}$, depending on river discharge. The bottom of the structure is covered by substrate from the riverbed to increase roughness. The uppermost weir (fishway exit) has a sluice gate that is used to regulate flow within the fishway.

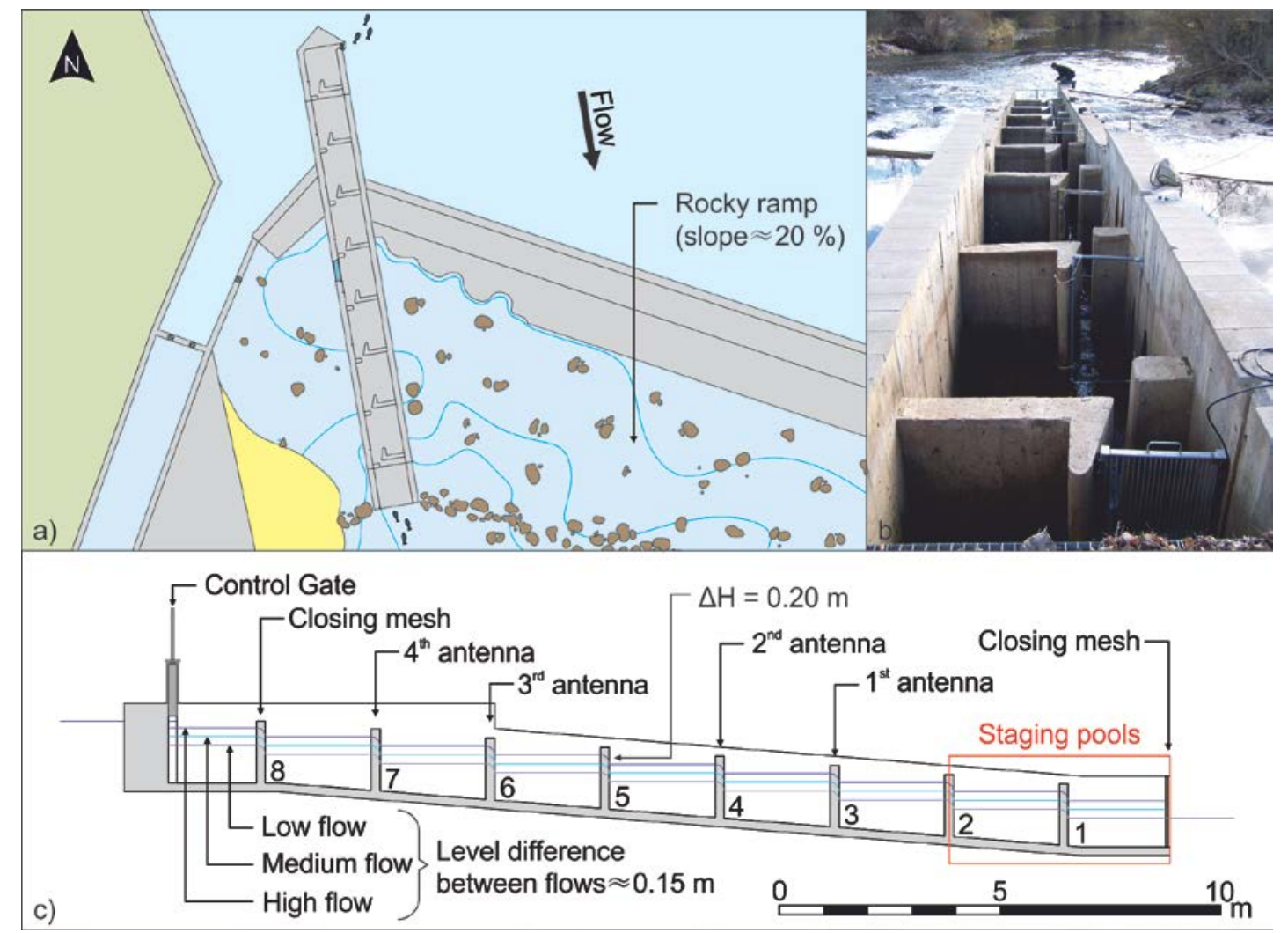

Fig. 2. (a) Plan view of fishway site location at the dam. (b): Antennas and top closing mesh installation. (c) longitudinal scheme of the experimentation design. 
Water temperature (Orpheus Mini, OTT Hydromet $\mathrm{GmbH}$ ) and water oxygen saturation (PCD-650 portable oximeter ${ }^{\circ}$ ) were monitored throughout the day at 30 minute intervals. Suspended sediments were collected three times daily and analyzed in the laboratory using gravimetric methods.

\section{Fish testing:}

We used a passive integrated transponder (PIT)-tag and antenna system to study fish behavior (Castro-Santos et al., 1996; Franklin et al., 2012).

Fish were caught by electrofishing (Erreka model; 2200 W, 5 A) one day prior to testing. They were captured trying to pass a chute, close to the tail of the small reservoir formed by the dam $-500 \mathrm{~m}$ upstream the fish ladder- in an apparent status of movement activity. All fish were tagged with PIT-tags, (Half-duplex tags measuring $23 \mathrm{~mm}$ long by $3.85 \mathrm{~mm}$ diameter, $0.6 \mathrm{~g}$ : TIRIS model RI-TRPWRHP; Texas Instruments, Dallas, Texas, USA). They were anaesthetized with a solution of 0.10 g/L MS-222 and tagged intraperitoneally by making an incision posterior to the left pectoral fin and gently inserting the tag into the peritoneal cavity (Castro-Santos and Vono, 2013). No fish died during or after the marking process. This method has been shown to have negligible effects on growth, survival, and behavior of many species (Ostrand et al., 2011; Ficke et al., 2012).

Fish were then transferred to the staging area (Figure 1), where they immediately recovered swimming and orientation capacities. Before starting the experiment, a conservative period of 24 hours was kept to acclimate fish to the new environment. The density of fish in this pool was 0.75 $\mathrm{kg} / \mathrm{m}^{3}$ for trials with trout and $1.22 \mathrm{~kg} / \mathrm{m}^{3}$ for trials with barbel and nase (both species were combined in the same pool). After the experiments, fish were sacrificed following the ethical guidelines of the EU legislation (Council, 1986).

\section{Ascent efficiency:}

Antennas were placed in all except for the middle slot, and each antenna was connected to a dedicated reader (ORFID ${ }^{\circ}$ Half Duplex reader with antenna Multiplexer, Figure 2 and Table I), programmed to interrogate the antennas at $14 \mathrm{~Hz}(3.5 \mathrm{~Hz}$ or $0.29 \mathrm{~s}$ per antenna). Fish were confined within the study section of the fishway by closing off the lowermost and uppermost slots 
with wire mesh. Once fish were introduced into the staging area they were allowed to rest for 24 hours. A second mesh screen was placed at the upstream end of the staging area to prevent fish from ascending the fishway during this period. Just before each experiment, the flow gate was opened up to achieve the desired water level in and discharge through the fishway. Once desired conditions were established, the mesh at the upstream end of the staging area was removed and fish were allowed to ascend the fishway volitionally.

Brown trout testing was carried out about two weeks before spawning and during a period when this species exhibits strong migratory activity in this area. Similar criteria were used for barbel and nase. Each species was subject to three trials, each lasting $24 \mathrm{~h}$ and performed under different flow conditions. Fish were not fed during experiments, although they could find some food in the fishway bottom and drifting in the current.

\section{Data analysis:}

\section{Onset of movement:}

During each trial, fish were able to make several ascents; once a fish reached the upper limit of the fishway or its maximum ascent distance it usually descended again to the resting pool and they tried to ascend again, thus accounting for several attempts. Attempts were not considered valid unless the fish was detected at least at Antenna 2, to separate exploratory movements from ascending movements. The last detection at Antenna 1 is considered as the start time of the attempt. Attempts in which fish were detected at the antenna furthest upstream were deemed "successful"; otherwise, they were deemed "failures".

\section{Motivation analysis:}

We quantified ascent motivation using three methods, evaluating the effects on each of flow discharge. The three methods were: 1) whether or not each fish made any attempts -analyzed using the logistic regression and compared in pairs with the chi-square test of independence; 2 ) the number of attempts staged by those fish that tried to ascend -analyzed using a one-way analysis of variance (ANOVA), with a Tukey's HSD test and compared with a multiple-range test; and 3) the attempt rate. 
Attempt rate was included in the analysis as an indicator of motivation, and was quantified using survival analysis (stratified proportional hazard model; (Castro-Santos, 2004). For those fish that staged at least one attempt, the time between the start of the trial and the first detection constituted the first attempt time, resulting in an uncensored observation. Subsequent attempt times were the time between the start of the attempt and the start of the previous attempt. The time between the start of the last attempt and the end of the trial was a censored observation. Fish that did not stage any attempt were included as censored observations, with attempt time equal to the duration of the trial (Castro-Santos, 2004; Castro-Santos et al., 2013).

\section{Passage analysis:}

Of those fish that staged attempts, passage performance was analyzed using an additional three metrics: 1) Success: proportion of ascending fish that reached the uppermost antenna -statistically analyzed with logistic regression; 2) Height exceeded: proportion of fish exceeding a specific height, censoring fish that reached the uppermost antenna -height = $1 \mathrm{~m}$; and 3) Transit time: minimum time to travel between the lowest and uppermost antenna -analyzed using stratified proportional hazard regression. In each case effect of flow discharge on performance were measured.

All statistical analyses were performed using SAS software (version 9.4).

\section{Results}

Brown trout trials were conducted between 26-November and 2-December, 2010; barbel and nase were tested together in trials conducted between 31 - May and 5 - June, 2011 (Table I). Water temperature fluctuated over the course of each day. During the brown trout experiments it ranged from $2.8-5.6^{\circ} \mathrm{C}$ and during the cyprinid experiments it ranged from $7.6-12.0^{\circ} \mathrm{C}$. Oxygen saturation was $100 \%$ and $\mathrm{pH}$ varied from 7.9 to 8.1. Suspended sediments were always less than 5 $\mathrm{mg} / \mathrm{L}$. 
Table I. Date, time and flow rate of the trials for the species under study. Hours are in solar time (12:00 $\mathrm{h}$ coincides with the highest sun elevation).

\begin{tabular}{|c|c|c|c|c|c|c|}
\hline & \multicolumn{2}{|c|}{ First test } & \multicolumn{2}{|c|}{ Second test } & \multicolumn{2}{|c|}{ Third test } \\
\hline & Trout & Barbel \& Nase & Trout & Barbel \& Nase & Trout & Barbel \& Nase \\
\hline Start date & $11 / 26 / 2010$ & $05 / 31 / 2011$ & $11 / 29 / 2010$ & $06 / 02 / 2011$ & $12 / 01 / 2010$ & 06/04/2011 \\
\hline $\begin{array}{l}\text { Start solar } \\
\text { time }\end{array}$ & $14: 30 \mathrm{~h}$ & $08: 00 \mathrm{~h}$ & $12: 30 \mathrm{~h}$ & $08: 00 \mathrm{~h}$ & $16: 30 \mathrm{~h}$ & $08: 00 \mathrm{~h}$ \\
\hline $\begin{array}{l}\text { Discharge } \\
\text { flow }\end{array}$ & \multicolumn{2}{|c|}{$\begin{array}{c}\text { Medium } \\
\left(0.334 \pm 0.006 \mathrm{~m}^{3} / \mathrm{s}\right)\end{array}$} & \multicolumn{2}{|c|}{$\begin{array}{c}\text { High } \\
\left(0.402 \pm 0.006 \mathrm{~m}^{3} / \mathrm{s}\right)\end{array}$} & \multicolumn{2}{|c|}{$\begin{array}{c}\text { Low } \\
\left(0.245 \pm 0.005 \mathrm{~m}^{3} / \mathrm{s}\right)\end{array}$} \\
\hline
\end{tabular}

Water velocity in the slots was different depending on the fishway flow and the local bottom slope (Table II). Flow was obtained through dilution gauging, using Rhodamine WT, replicating the hydraulic conditions of the experiment without fish. Maximum velocity always occurred on the sixth slot, where slope exceeded 9\%. The lower notches showed slower velocities, because they were influenced by the backwater level in the river, increasing their depth and decreasing the drop between pools.

Table II. Cumulative height, local slope between pools and mean water velocity within the slots under three different flow tests (see Figure 1). Slots are numbered from bottom to top.

\begin{tabular}{|c|c|c|c|c|c|}
\hline \multirow{2}{*}{$\begin{array}{c}\text { Slot } \\
\text { (Antenna) }\end{array}$} & \multirow{2}{*}{$\begin{array}{l}\text { Cumulative } \\
\text { height (m) }\end{array}$} & \multirow[b]{2}{*}{ Slope (\%) } & \multicolumn{3}{|c|}{ Mean water velocity $\left(\mathrm{m} \cdot \mathrm{s}^{-1}\right)$} \\
\hline & & & $\begin{array}{c}\text { Low flow } \\
\left(0.245 \mathrm{~m}^{3} \cdot \mathrm{s}^{-1}\right)\end{array}$ & $\begin{array}{l}\text { Medium flow } \\
\left(0.334 \mathrm{~m}^{3} \cdot \mathrm{s}^{-1}\right)\end{array}$ & $\begin{array}{l}\text { High flow } \\
\left(0.402 \mathrm{~m}^{3} \cdot \mathrm{s}^{-1}\right)\end{array}$ \\
\hline $3(1)$ & 0.19 & 7.14 & 1.45 & 1.77 & 1.81 \\
\hline $4(2)$ & 0.40 & 8.24 & 1.59 & 1.79 & 1.87 \\
\hline $5(--)$ & 0.58 & 6.70 & 1.64 & 1.89 & 1.94 \\
\hline $6(3)$ & 0.82 & 9.41 & 1.82 & 1.96 & 2.08 \\
\hline $7(4)$ & 1.01 & 6.94 & 1.60 & 1.75 & 1.87 \\
\hline
\end{tabular}

A total of 20 trout, 17 barbel, and 8 nase were tested in the fishway (Table III). Nase were slightly larger than barbel, and both cyprinids were slightly larger than trout, but this difference was not significant $(P>0.127)$. 
Table III. Biological and environmental conditions. Sequence indicates the order in which trials were performed. Sample Size ( $\mathrm{n}$ ) as total number of attempts and available fish (between parentheses), number of fish that staged attempts within each trial (Attempting), and total number of attempts staged (Attemptstot) for each species-treatment combination. Condition Factor $(\mathrm{CF})=100 \cdot \mathrm{M} \cdot \mathrm{FL}^{-3}$ (M: mass $(\mathrm{g})$; FL: Fork Length $\left.(\mathrm{cm})\right)$. (mean $\left.\pm \mathrm{SD}\right)$.

\begin{tabular}{|c|c|c|c|c|c|c|c|c|}
\hline \multirow[t]{2}{*}{ Species } & \multirow[t]{2}{*}{ Flow rate } & \multirow[t]{2}{*}{ Sequence } & \multirow[t]{2}{*}{ Attempting } & \multirow[t]{2}{*}{ Attemptstot } & \multicolumn{2}{|c|}{$\begin{array}{l}\text { Fork length } \\
\text {-FL- mm }\end{array}$} & \multicolumn{2}{|c|}{$\begin{array}{l}\text { Condition Factor } \\
\qquad-\mathrm{CF}-\mathrm{g} \cdot \mathrm{cm}^{-3}\end{array}$} \\
\hline & & & & & Male & Female & Male & Female \\
\hline \multirow{3}{*}{$\begin{array}{l}\text { Brown trout } \\
n=32(20)\end{array}$} & Low & 3 & 4 & 5 & $219.5 \pm 32.8$ & $223.2 \pm 36.5$ & $1.14 \pm 0.08$ & $1.15 \pm 0.11$ \\
\hline & Medium & 1 & 8 & 11 & & & & \\
\hline & High & 2 & 11 & 16 & & & & \\
\hline \multirow{3}{*}{$\begin{array}{c}\text { Barbel } \\
\mathrm{n}=106(17)\end{array}$} & Low & 3 & 9 & 26 & $241.8 \pm 58.2$ & $250.3 \pm 46.9$ & $1.50 \pm 0.17$ & $1.42 \pm 0.09$ \\
\hline & Medium & 1 & 10 & 54 & & & & \\
\hline & High & 2 & 9 & 26 & & & & \\
\hline \multirow{3}{*}{$\begin{array}{c}\text { Nase } \\
n=31(8)\end{array}$} & Low & 3 & 3 & 8 & $238.6 \pm 75.0$ & $286.7 \pm 40.7$ & $1.20 \pm 0.16$ & $1.28 \pm 0.11$ \\
\hline & Medium & 1 & 4 & 17 & & & & \\
\hline & High & 2 & 3 & 6 & & & & \\
\hline
\end{tabular}




\section{Motivation analysis:}

Motivation varied by species (Table IV). Barbel and nase appeared to be more motivated than brown trout: they made more attempts $(P<0.001)$ and had a greater proportion attempting, although difference in proportion was not significant $(P=0.340)$. The cyprinids staged attempts sooner than the trout $(P<0.001)$ (Figure 3$)$. Although barbel staged their first attempt sooner than nase $(P=0.015)$ on subsequent attempts barbel at a slightly greater attempt rate than nase $(P=0.069)$.

Table IV. Comparative results for attempt proportion and attempt number among species. P-value (P) between parenthesis and significant differences represented by letters. Number of attempts: mean \pm SE

\begin{tabular}{|c|c|c|c|c|c|}
\hline \multirow[t]{2}{*}{ Species } & \multicolumn{3}{|c|}{$\begin{array}{l}\text { Attempt - not attempt } \\
\begin{array}{l}\text { (\% attempting) } \\
(P=0.340)\end{array}\end{array}$} & \multicolumn{2}{|c|}{$\begin{array}{c}\text { Number of attempts } \\
\left.\text { (n attempts } \cdot \mathrm{n} \text { fish with attempt }{ }^{-1}\right) \\
(\mathrm{P}<0.001)\end{array}$} \\
\hline & $\%$ & Tukey' & HSD test & Mean $\pm \mathrm{SE}$ & Tukey's HSD test \\
\hline Brown trout & $38.8 \%$ & a & & $1.4 \pm 0.1$ & $a$ \\
\hline Barbel & $58.8 \%$ & & $b$ & $3.8 \pm 0.4$ & $b$ \\
\hline Nase & $50.0 \%$ & a & $\mathrm{b}$ & $2.0 \pm 0.3$ & a \\
\hline
\end{tabular}

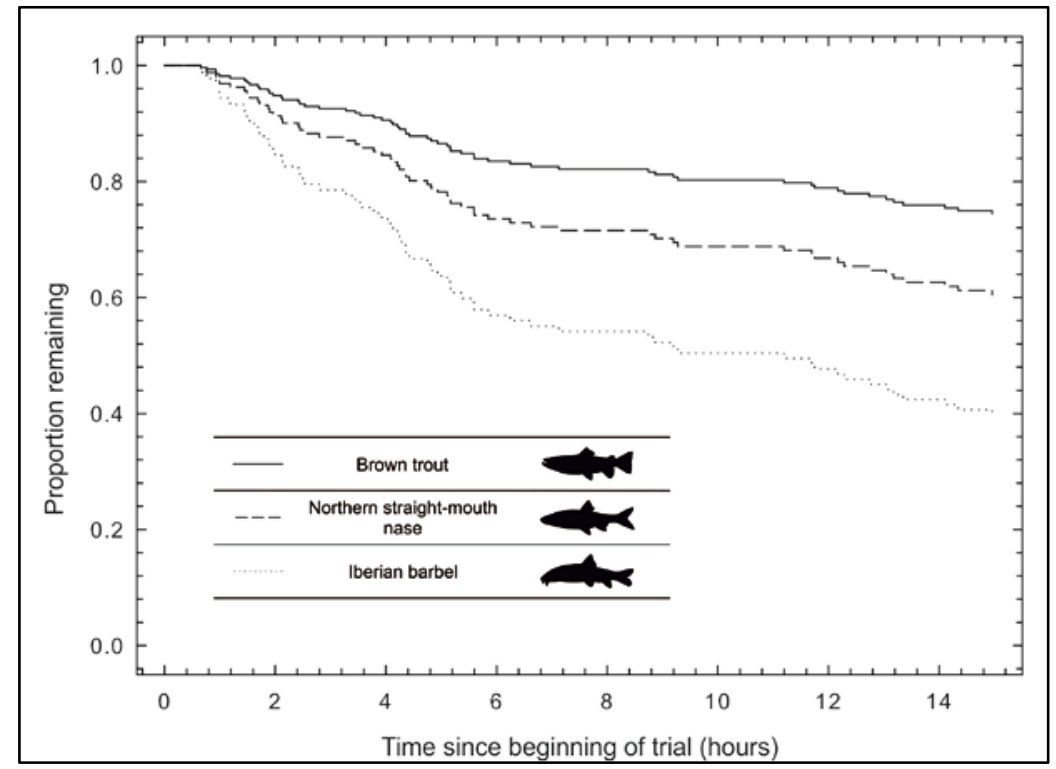

Fig. 3. Survivorship curves showing time to stage the first attempt. Curves are depletion functions, showing the effects of different attempt rates - barbel had the fastest attempt rate and so produced a greater proportion attempting. 
Discharge affected motivation of both trout and barbel (Table V). More trout staged attempts at high flows than at low or medium flows (although significance was marginal: $\mathrm{P}=0.055$ and Logistic regression coefficient \pm SE value for proportion attempting parameter at high flow $=$ $1.235 \pm 0.597 ;$ and $\mathrm{P}=0.096$ and attempt rate hazard model coefficient at high flow $=0.716 \pm$ $0.402)$.

Table V. P-values of the effect of flow discharge on motivation intraspecific metrics.

\begin{tabular}{lccc}
\cline { 2 - 4 } & \multicolumn{3}{c}{ Motivation parameter (p-values) } \\
\cline { 2 - 4 } & Attempt-not attempt & Number of attempts & Attempt rate \\
\hline Brown trout & 0.055 & 0.844 & 0.096 \\
Barbel & 0.924 & 0.004 & 0.005 \\
Nase & 0.880 & 0.528 & 0.301 \\
\hline
\end{tabular}

Among barbel the number of attempts was greatest at the medium flow condition $(P=0.004$; mean attempts \pm SE value at medium flow $=5.40 \pm 0.58$; high flow $=2.89 \pm 0.61$; low flow $=$ $2.89 \pm 0.48)$ and the attempt rate was faster $(P=0.005$; coefficients for high flow $=-0.654 \pm$ 0.250 and low flow $=-0.690 \pm 0.251$ ).

\section{Passage analysis:}

\section{Success:}

Success rates ( $n$ success $\cdot n$ attempts ${ }^{-1}$ ) were similar among species $(P=0.989$; trout $=0.70$, barbel $=0.71$, nase $=0.70)$. Trout had the lowest success at the highest flows $(P=0.029)$

$\underline{\text { Height exceeded: }}$

Another index of passage is the proportion of fish ascending to a given height. Although most of the fish that made some attempt reached the upper level, not all of them were successful within 24 hours of testing.

There were no significant differences between three species $(P=0.217)$, except a slightly divergence among barbel and trout $(P=0.082)$. Flow rate was only important for trout at high flows. This species attained the last antenna in a lower proportion from medium and low discharge $(P=0.042)$, although their risk rate is low $(0.100)$. 


\section{$\underline{\text { Transit time }}$}

Transit time data do not follow a normal distribution. Therefore, the median, and not the mean, is used as a representative information.

Transit time of rheophilic cyprinids were similar $(P=0.624)$ (Median of transit time: barbel = $1013 \mathrm{~s}$ and nase $=322 \mathrm{~s}$ ) and both species ascended the fish ladder faster than trout (Figure 4) $(P=0.012$; median of transit time for trout $=2090 \mathrm{~s})$. Post-hoc tests showed significant differences between trout and barbel $(P=0.008)$ and between trout and nase $(P=0.011)$. Transit time was unaffected by fishway discharge.

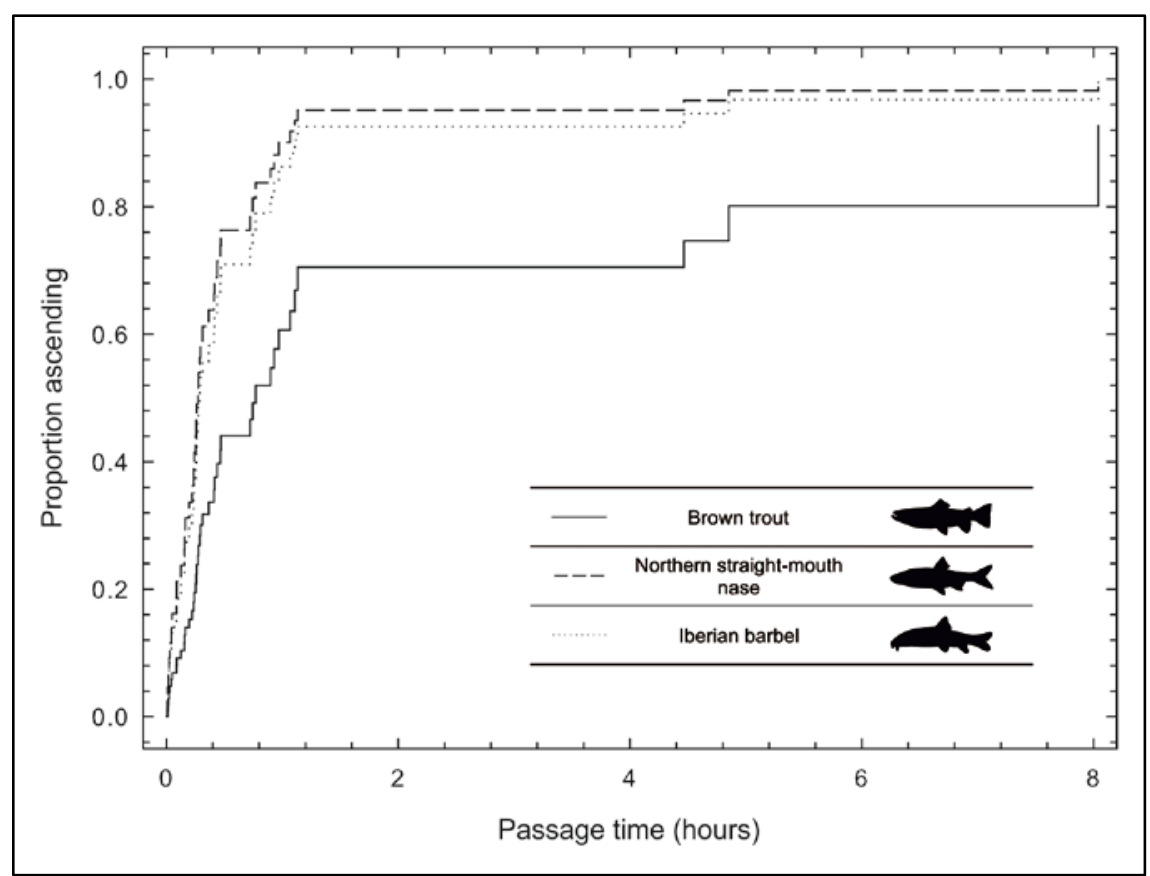

Fig. 4. Relative frequency of transit time for trout, nase and barbel.

\section{Discussion}

This study has shown that both barbel and nase were better able to pass a vertical slot fishway than brown trout, and that superior performance appeared to be more driven by motivation than by actual ability to ascend the structure once fish passed the first slot.

These expectations led to recommendations that fishway designs for barbel and nase be less challenging than those for trout (Puertas et al., 2012).

It was founded in part on the belief that cyprinids are weaker swimmers than trout. This believe has been discredited: sprinting ability of barbel and nase is very similar to that of trout 
(Castro-Santos et al., 2013; Sanz-Ronda et al., 2015), and the low expectations of these two species appear to be unjustified.

Having once started the ascent, the three species showed remarkable similarities in their likelihood of passage success. Difference in performance was still evident, however, with the cyprinids passing much more quickly than the trout. It is likely that the reduced motivation and transit time exhibited by the trout was related in part to the lower temperatures experienced by that species. Motivation is one of the key factors driving passage performance, although it is rarely measured (Castro-Santos, 2004; Wagner et al., 2012; Cooke and Hinch, 2013). However, the methodological approach used in this kind of studies probably stresses fish and influences on fish behavior.

At lower temperatures metabolic rates and sustained swim speeds are both reduced (Brett, 1964; Beamish, 1978; McKenzie and Claireaux, 2010; Yan et al., 2012). Several species of fish have been shown to exhibit reduced attempt rates at lower temperatures (Castro-Santos, 2002; Castro-Santos, 2004). These studies were performed during the period when all species were undergoing spawning migrations, however, and so the reduced performance of trout holds importance for their management and conservation.

Fishway discharge influenced overall ascent ability. It affected motivation, although it did not influence on passage, except delaying transit time for trout in high flows. Motivation of barbel was higher at medium flows, and for trout it was greater at high flows. Increased motivation in response to elevated velocities and flows has been widely reported in fish pass and swimming flume studies (Weaver, 1963; Castro-Santos, 2004; Castro-Santos et al., 2013).

Generally, in vertical slot fishways, the slot velocities are relatively unaffected by discharge (Rodríguez et al., 2006). Nevertheless, we observed changes in water velocity at the slots when flow increased in the fishway -it enlarged about $20 \%$ from low to high discharge- and also in the main recirculation areas at pools. It is likely that the changed behavior is a response to these factors.

Finally, a fact that is manifested in this experiment, as well as in similar ones, is the strong variation of the transit time, which was strongly skewed toward longer times, producing a large difference between mean and median (Gowans et al., 1999; White et al., 2010).

This suggests that the transit time depends more on the individuals own behavior than events dependent on factors under study. In addition, the median is the index that best represents 
the behavior of the sample. The distribution of transit times is consistent with diffusion theory (Castro-Santos et al., 2009), and is one reason that survival analysis techniques typically model the logarithm of time or of the hazard (event rate). Skewed distributions also indicate that movement is not strongly directed, and are characteristic of structures that impart reduced rates of movement, increased tortuosity, or migratory delay (Castro-Santos and Haro, 2003).

As with most fish species, further research is needed on the interplay between swimming abilities, migration habits and behavior inside fish passes of Iberian native species and specifically for cyprinids. If similar studies are performed over a range of fishway designs and sizes it will become possible to improve both performance and cost-effectiveness of engineered fish passage structures, and for their conservation generally.

\section{Acknnowledgements}

This research has been supported by Castilla y León Regional Government: project VA299B112: "Swimming capacity evaluation in Iberian fish". Francisco Javier Bravo-Córdoba is supported by a PhD grant from the University of Valladolid PIF-UVa 2011. León Fisheries Service facilitated their installations and staff for experimentation. We specially thank to the research group GEA-Ecohidraulica their help on fieldwork.

\section{References}

Alexandre C., Quintella B. R., Silva A., Mateus C., Romão F., Branco P., Ferreira M. T. and Almeida P. R. 2013. Use of electromyogram telemetry to assess the behavior of the Iberian barbel (Luciobarbus bocagei Steindachner, 1864) in a pool-type fishway. Ecological Engineering. 51, 191-202.

Armstrong G., Aprahamian M., Fewings G., Gough P., Reader N. and Varallo P. 2004. Environment agency fish pass manual: guidance notes on the legislation, selection and approval of fish passes in England and Wales. Environment Agency. Wales, United Kingdom.

Beamish F. 1978. Swimming capacity, locomotion. In 'Fish Physiology. Vol. VII'.(Eds WS Hoar and DJ Randall.) pp. 101-187. 
Branco P., Santos J. M., Katopodis C., Pinheiro A. and Ferreira M. T. 2013. Effect of flow regime hydraulics on passage performance of Iberian chub (Squalius pyrenaicus) (Günther, 1868) in an experimental pool-and-weir fishway. Hydrobiologia, 714, 145-154.

Brett J. R. 1964. The respiratory metabolism and swimming performance of young sockeye salmon. Journal of Fisheries Research Board of Canada. 21, 1183-1226.

Bunt C. M., Castro-Santos T. and Haro A. 2011. Performance of fish passage structures at upstream barriers to migration. River Research and Appications. 28, 457-478.

Castro-Santos T. 2002. Swimming performance of upstream migrant fishes: new methods, new perspectives. Doctoral dissertation, University of Massachusetts Amherst.

Castro-Santos T. 2004. Quantifying the combined effects of attempt rate and swimming capacity on passage through velocity barriers. Canadian Journal of Fisheries and Aquatic Sciences. 61, 1602-1615.

Castro-Santos T. 2005. Optimal swim speeds for traversing velocity barriers: an analysis of volitional high-speed swimming behavior of migratory fishes. Journal of Experimental Biology. 208, 421-432.

Castro-Santos T. and Haro A. 2003. Quantifying migratory delay: a new application of survival analysis methods. Canadian Journal of Fisheries and Aquatic Sciences. 60, 986-996.

Castro-Santos T. and Haro A. 2010. Fish guidance and passage at barriers. In: Domenici P. B. and Kapoor B. G.(eds.) Fish Locomotion: An Eco-ethological Perspective, Science Publishers, $48-62$.

Castro-Santos T. and Perry R. W. 2012. Time-to-event analysis as a framework for quantifying fish passage performance. In: Telemetry techniques: a user guide for fisheries research. American Fisheries Society, Bethesda, Maryland, 427-452.

Castro-Santos T. and Vono V. 2013. Posthandling Survival and PIT Tag Retention by AlewivesA Comparison of Gastric and Surgical Implants. North American Journal of Fisheries Management. 33, 790-794.

Castro-Santos T., Haro A. and Walk S. 1996. A passive integrated transponder (PIT) tag system for monitoring fishways. Fisheries Research., 28, 253-261.

Castro-Santos T., Cotel A. and Webb P. 2009. Fishway evaluations for better bioengineering: an integrative approach. Challenges for Diadromous Fishes in a Dynamic Global Environment, 557. 
Castro-Santos T., Sanz-Ronda J. and Ruiz-Legazpi J. 2013. Breaking the speed limit-comparative sprinting performance of brook trout (Salvelinus fontinalis) and brown trout (Salmo trutta). Canadian Journal of Fisheries and Aquatic Sciences. 70(2), 280-293.

Clough S., Lee-Elliott I., Turnpenny A., Holden S. and Hinks C. 2004. Swimming speeds in fish: phase 2. R\&D Technical Report W2-049/TR1. Environment Agency, Bristol.

Cooke S. J. and Hinch S. G. 2013. Improving the reliability of fishway attraction and passage efficiency estimates to inform fishway engineering, science, and practice. Ecological Engineering. 58, 123-132.

Council E. 1986. EEC Council Directive 86/609/EEC of 24 November 1986 on the approximation of laws, regulations and administrative provisions of the Member States regarding the protection of animals used for experimental and other scientific purposes. 358, 1-28.

Doadrio I. 2001. Atlas y libro rojo de la ictiofauna continental española, NIMAM-CSCI, Madrid.

Doadrio I., Perea S., Garzón-Heydt P. and Y González J. 2011. Ictiofauna continental española. Bases para su seguimiento. Ministerio de Medio Ambiente y Medio Rural y Marino, Centro de Publicaciones.

Elvira B., Almodóvar A. and Nicola G. G. 1998. Impacto de las obras hidráulicas en la ictiofauna: Dispositivos de paso para peces en las presas de España, Organismo Autónomo Parques Nacionales, Madrid.

Ficke A. D., Myrick C. A. and Kondratieff M. C. 2012. The effects of PIT tagging on the swimming performance and survival of three nonsalmonid freshwater fishes. Ecological Engineering. 48, 86-91.

Franklin A. E., Haro A., Castro-Santos T. and Noreika J. 2012. Evaluation of nature-like and technical fishways for the passage of alewives at two coastal streams in New England. Transactions of American Fisheries Society. 141, 624-637.

Gowans A. R., Armstrong J. D. and Priede I. G. 1999. Movements of adult Atlantic salmon in relation to a hydroelectric dam and fish ladder. Journal of Fish Biology. 54, 713-726.

James R. S. and Johnston I. A. 1998. Influence of spawning on swimming performance and muscle contractile properties in the short-horn sculpin. Journal of Fish Biology. 53, 485-501. 
Larinier M. 2002. (a) Biological factors to be taken into account in the design of fishways, the concept of obstructions to upstream migration. Bulletin Francais de la Pêche et la Pisciculture. $364,28-38$.

Larinier M. 2002. (b) Pool fishways, pre-barrages and natural bypass channels. Bulletin Francais de la Pêche et la Pisciculture. 364, 54-82.

Makrakis S., Miranda L. E., Gomes L. C., Makrakis M. C. and Junior H. M., 2010. Ascent of neotropical migratory fish in the Itaipu Reservoir fish pass. River Research and Applications. 27, 511-519.

Mallen-Cooper M. 1999. Developing fishways for non-salmonid fishes: a case study from the Murray River in Australia. Innovations in fish passage technology, 173.

Mallen-Cooper M. and Brand D. A. 2007. Non-salmonids in a salmonid fishway: what do 50 years of data tell us about past and future fish passage? Fisheries Management and Ecology. $14,319-332$.

Mateus C. S., Quintella B. R. and Almeida P. R. 2008. The critical swimming speed of Iberian barbel Barbus bocagei in relation to size and sex. Journal of Fish Biology. 73, 1783-1789.

McKenzie D. J. and Claireaux G. 2010. Effects of environmental factors on the physiology of sustained aerobic exercise. In: Fish Locomotion-an ethoecological perspective.Science Publishers, New Hampshire, 296-332.

Noonan M. J., Grant J. W. and Jackson C. D. 2012. A quantitative assessment of fish passage efficiency. Fish and Fisheries. 13, 450-464.

Ostrand K. G., Zydlewski G. B., Gale W. L. and Zydlewski J. D. 2011. Long term retention, survival, growth, and physiological indicators of juvenile salmonids marked with passive integrated transponder tags. American Fisheries Society Symposium, 76.

Pedersen L., Koed A. and Malte H. 2008. Swimming performance of wild and F1-hatcheryreared Atlantic salmon (Salmo salar) and brown trout (Salmo trutta) smolts. Ecology of Freshwater Fish. 17, 425-431.

Plaut I. 2002. Does pregnancy affect swimming performance of female Mosquitofish, Gambusia affinis? Functional Ecology. 16, 290-295.

Pompeu P. and Martinez C. B. 2007. Swimming performance of the migratory Neotropical fish Leporinus reinhardti (Characiformes: Anostomidae). Neotropical Ichthyology. 5, 139-146. 
Puertas J., Cea L., Bermúdez M., Pena L., Rodríguez Á, Rabuñal J. R., Balairón L., Lara Á and Aramburu E. 2012. Computer application for the analysis and design of vertical slot fishways in accordance with the requirements of the target species. Ecological Engineering. 48, 51-60.

Rajaratnam N., Van der Vinne G. and Katopodis C. 1986. Hydraulics of vertical slot fishways. Journal Hydraulic Engineering. 112, 909-927.

Rodríguez T. T., Agudo J. P., Mosquera L. P. and González E. P. 2006. Evaluating vertical-slot fishway designs in terms of fish swimming capabilities. Ecological Engineering. 27, 37-48.

Romão F., Quintella B. R., Pereira T. J. and Almeida P. R. 2012. Swimming performance of two Iberian cyprinids: the Tagus nase Pseudochondrostoma polylepis (Steindachner, 1864) and the bordallo Squalius carolitertii (Doadrio, 1988). Journal of Applied Ichthyology. 28, 26-30.

Rosgen D. L. and Silvey H. L., 1996. Applied river morphology, Wildland Hydrology Pagosa Springs, Colorado.

Sanz-Ronda,F.J. , Bravo-Córdoba, F.J. , and Martínez de Azagra, A. 2010. Estaciones de aforo Vflat y peces migradores de la Península Ibérica: problemas y soluciones. Ingeniería civil, 158, $111-119$.

Sanz-Ronda F. J., Ruiz-Legazpi J., Bravo-Córdoba F. J., Makrakis S. and Castro-Santos T. 2015. Sprinting performance of two Iberian fish: Luciobarbus bocagei and Pseudochondrostoma duriense in an open channel flume. Ecological Engineering. 83, 61-70.

Silva A. T., Santos J. M., Franco A. C., Ferreira M. T. and Pinheiro A. N. 2009. Selection of Iberian barbel Barbus bocagei (Steindachner, 1864) for orifices and notches upon different hydraulic configurations in an experimental pool-type fishway. Journal of Applied Ichthyoogy. 25, 173177.

Silva A. T., Katopodis C., Santos J. M., Ferreira M. T. and Pinheiro A. N. 2012. Cyprinid swimming behaviour in response to turbulent flow. Ecological Engineering. 44, 314-328.

Stuart I. G. and Berghuis A. P. 2002. Upstream passage of fish through a vertical-slot fishway in an Australian subtropical river. Fisheries Management and Ecology. 9, 111-122.

Thiem J. D., Broadhurst B. T., Lintermans M., Ebner B. C., Clear R. C. and Wright D. 2013. Seasonal differences in the diel movements of Macquarie perch (Macquaria australasica) in an upland reservoir. Ecology of Freshwater Fish. 22, 145-156. 
Travade F. and Larinier M. 2002. Monitoring techniques for fishways. Bulletin Francais de la Pêche et la Pisciculture. 364, 166-180.

Wagner R. L., Makrakis S., Castro-Santos T., Makrakis M. C., Pinheiro J. H. and Belmont R. F. 2012. Passage performance of long-distance upstream migrants at a large dam on the Paraná River and the compounding effects of entry and ascent. Neotropical Ichthyology. 10, 785-795.

Wang R. W., David L. and Larinier M. 2010. Contribution of experimental fluid mechanics to the design of vertical slot fish passes. Knowledge and Managamen of Aquatic Ecosystems. 396, 02.

Weaver C. R. 1963. Influence of water velocity upon orientation and performance of adult migrating salmonids. Fishery Bulletin. 63, 24.

White L. J., Harris J. H. and Keller R. J. 2010. Movement of three non-salmonid fish species through a low-gradient vertical-slot fishway. River Research and Applications. 27, 499-510.

Yan G. J., He X. K., Cao Z. D. and Fu S. J. 2012. The trade-off between steady and unsteady swimming performance in six cyprinids at two temperatures. Journal of Thermal Biology. 37, 424-431. 


\section{RESULTADOS II: Selecting the best technical fishway design for Iberian barbel, Luciobarbus bocagei (Steindachner, 1864): vertical slots versus submerged notches with bottom orifice.}

Francisco Javier BRAVO-CÓRDOBA ${ }^{* 1}$, Francisco Javier SANZ-RONDA ${ }^{1}$, Jorge RUIZ-LEGAZPI ${ }^{1}$, Jorge VALBUENA-CASTRO ${ }^{1}$, Sergio MAKRAKIS ${ }^{2}$

En fase de revisión en la revista Ecological Engineering.

${ }^{1}$ U. D. de Hidráulica e Hidrología.

Grupo de Ecohidráulica Aplicada (GEA-ecohidraulica.org)

Departamento de Ingeniería Agrícola y Forestal.

E.T.S.II.AA. Universidad de Valladolid.

Avda. Madrid, 44; 34004 Palencia (Spain)

francisco.bravo@iaf.uva.es

+34979108358 (Ph.)

+34979108302 (Fax)

${ }^{2}$ Universidade Estadual Do Oeste do Parana.

Rua da Faculdade, 645 Toledo-Paraná, (Brasil) 


\section{Abstract}

When engineers and biologists face a fishway design, many issues need to be considered, the type of fishway being the first and foremost. It is an especially complex issue in areas with species whose migratory and swimming behavior are as yet poorly known. The present study focuses on the capacity of the Iberian barbel (Luciobarbus bocagei) to ascend two of the most common types of technical fishway on the Iberian Peninsula: vertical slots, and submerged notches with bottom orifice. Both types were studied and compared in terms of motivation (as the proportion of attempts and time until the first attempt) and ascent ability (as the success rate and transit time).

Barbel did not show any difference in motivation between fishway types and easily ascended both, although ascent was faster in the submerged notches with bottom orifice fishway. Turning pools had a significant influence on transit time, resulting in a slight delay, while smaller fish were slower in vertical slots.

These results may help fishway designers in their decision making, mainly in Mediterranean areas with similar habitats and species.

Keywords: Potamodromous fish, cyprinids, PIT tag, fish length, stepped fishways, turning pool, survival analysis

\section{Introduction}

Transverse riverbed structures (dams, gauging stations, culverts, and others) have been increasingly used in recent decades worldwide, leading to a high degree of current river fragmentation (Baudoin et al., 2015). At the same time, there is progressively more knowledge and environmental awareness about the need for free movement of ichthyofauna along watercourses in order to complete their lifecycles.

In the case of the Iberian Peninsula, barriers to movement are among the principal threats affecting endemic fish (Doadrio et al., 2011). One of the most common of these species is the Iberian barbel (Luciobarbus bocagei). Like other potamodromous cyprinids, barbels usually ascend to headwaters to spawn in spring. Their swimming performance during migration 
period has recently been studied under field conditions, showing a swimming ability similar to brown trout (Sanz-Ronda et al., 2015, 2016)., Many fish pass solutions have accordingly been designed in recent decades to improve longitudinal connectivity. Technical stepped fishways have been the most popular designs in Spain (Elvira et al., 1998), used first in salmonid areas and, since the present century, in cyprinid reaches. Vertical slot fishways (VS) and submerged notch with bottom orifice (SNBO) fishways are the most common types and there is no difference in building cost between them. There are many references about their hydraulic performance and design (Clay, 1995; Larinier, 2002; Fuentes-Pérez et al., 2014, 2016). However, despite the particularities of Iberian rivers and ichthyofauna, field biological assessments of these two types of fishway in terms of hydraulic features have been very scarce (Sanz-Ronda et al., 2015, 2016; Rocaspana-Jove et al., 2012; Ordeix et al., 2011; Aparicio et al., 2012). This means an added difficulty for engineers and biologists when choosing the best fishway option.

The purpose of this paper is to evaluate and compare the capacity of the Iberian barbel in terms of motivation, transit time and passage success in two of the most common technical fishway types: VS and SNBO. The aim is to aid engineering design, implementation and management decisions in many Iberian rivers and other Mediterranean watercourses with similar species.

\section{Methods}

\section{Study site and fishways}

The experiments were carried out in two fishways at the Vadocondes (VS) and Guma (SNBO) hydropower plants (River Duero, province of Burgos in north-central Spain; $41^{\circ} 37^{\prime} 59.1^{\prime \prime} \mathrm{N} 3^{\circ}$ $33^{\prime} 44.3^{\prime \prime}$ W; Fig. 1). At these locations, the river drains a watershed of $7398 \mathrm{~km}^{2}$ with a mean annual discharge of about $17.5 \mathrm{~m}^{3} / \mathrm{s}$ (data from the Vadocondes gauging station, code: 2522; www.saihduero.es). This river reach belongs to the epipotamon area with an average altitude of around 810 meters above sea level. The zone corresponds to category C6, i.e. a silt-clay bed stream of moderate sinuosity with a slope of 0.001-0.02 m/m (Rosgen and Silvey. 1996), the most abundant native fish species being the Iberian barbel. 


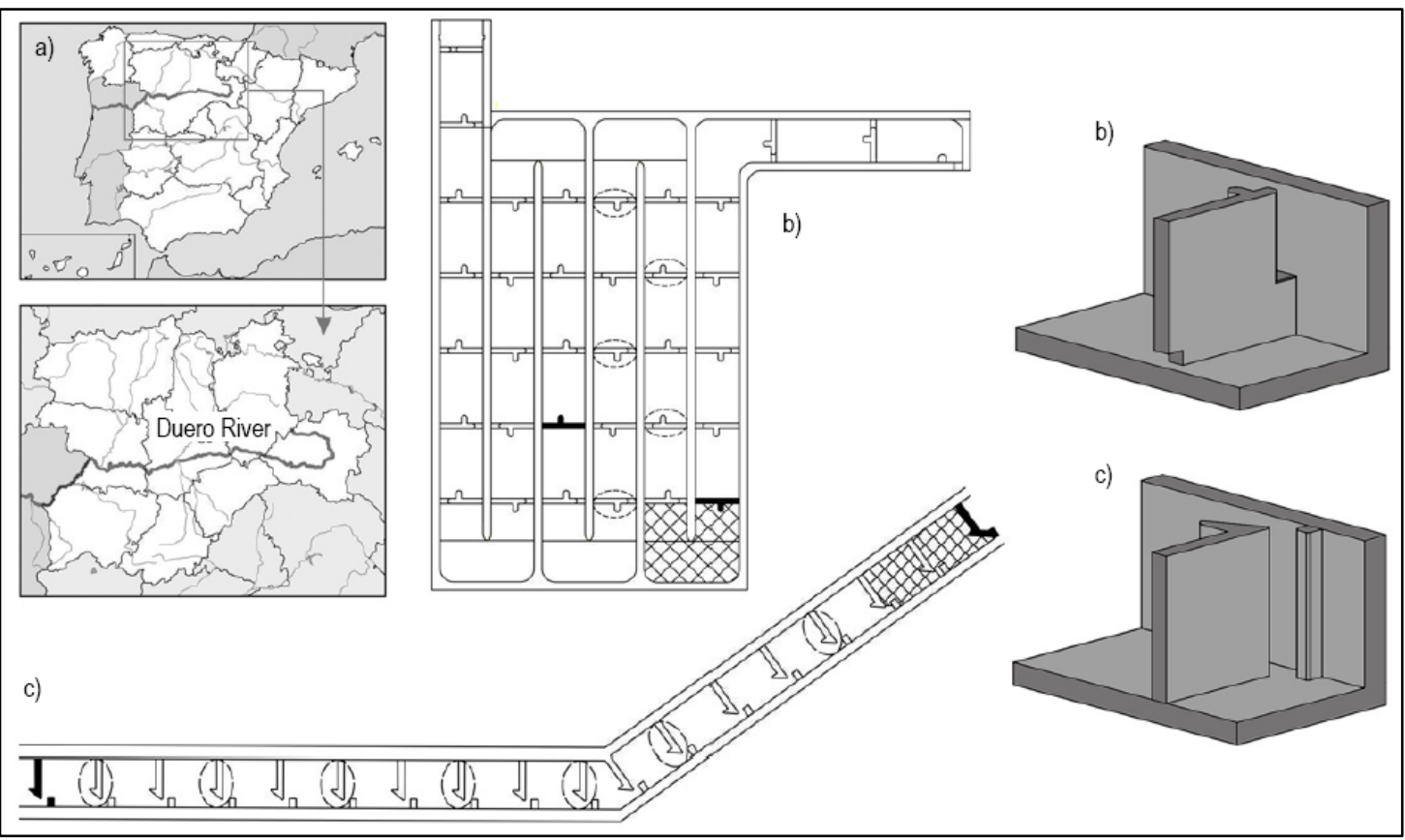

Fig. 1. a) Study site location: Duero River, Castilla y León region (Northwest Spain). b) Vertical slots scheme (VS). c) Submerged notches with bottom orifice scheme (SNBO). Black slots: closing mesh. Dotted circles: PIT antennas; striped pools: staging pools.

Both fish ladders were built about $3 \mathrm{~km}$ apart. They were designed for cyprinids with low volumetric energy dissipation $<125 \mathrm{~W} \cdot \mathrm{m}^{-3}$ (Table 1 ; design details). Their bottoms were covered by substrate from the riverbed to increase roughness, and discharge can be regulated by a sluice gate located in the flow entrance.

\section{Fish testing}

We used a Passive Integrated Transponder (PIT-tag) and antenna system to study how fish face complex hydraulic flows during the ascent. Experimental fish were caught by electrofishing one day prior to testing in a river branch $1 \mathrm{~km}$ downstream of the VS fishway. For more details of handling procedures, see Sanz-Ronda et al., (2015). 
Table 1. Geometrical characteristics of the fishway types. VS: Vertical slot; SNBO: submerged notches with bottom orifice.

\begin{tabular}{lll}
\hline & VS & SNBO \\
\hline Slope & $6.52 \%$ & $8.77 \%$ \\
Flow discharge* & $0.25 \pm 0.01 \mathrm{~m}^{3} / \mathrm{s}$ & $0.27 \pm 0.01 \mathrm{~m}^{3} / \mathrm{s}$ \\
Volumetric Energy Dissipation** & $122 \pm 7 \mathrm{~W} / \mathrm{m}^{3}$ & $121 \pm 10 \mathrm{~W} / \mathrm{m}^{3}$ \\
Pool dimension (length $x$ width $x$ depth) & $2.10 \times 1.60 \times 0.92 \mathrm{~m}$ & $2.60 \times 1.60 \times 1.32 \mathrm{~m}$ \\
Height drop between pools & $0.15 \mathrm{~m}$ & $0.25 \mathrm{~m}$ \\
Width of the notches & $0.20 \mathrm{~m}$ & $0.30 \mathrm{~m}$ \\
Water velocity at the notches*** & $1.48 \pm 0.08 \mathrm{~m} / \mathrm{s}$ & $1.79 \pm 0.12 \mathrm{~m} / \mathrm{s}$ \\
Bottom orifice size & None & $0.20 \times 0.20 \mathrm{~m}$ \\
Velocity at the orifices*** & None & $1.94 \pm 0.09 \mathrm{~m} / \mathrm{s}$ \\
\hline
\end{tabular}

*Obtained through dilution gauging, using Rhodamine WT, on previous trial dates

**Volumetric Energy Dissipation as the mean value of the pools under study

***Direct measurements with a Model 2100 propeller meter (Swoffer Instruments Inc.)

\section{Trials}

Antennas were placed along each fishway, covering a height of $2.25 \mathrm{~m}$ (14 straight pools in VS and 8 pools in SNBO, one of which was a turning pool with curved walls; Fig. 1). Each antenna was connected to a dedicated reader (ORFID ${ }^{\circ}$ Half Duplex reader with a Multiplexer antenna), programmed to query the antennas at $14 \mathrm{~Hz}(3.5 \mathrm{~Hz}$ or $0.29 \mathrm{~s}$ per antenna). Two Multiplexer antennas were used in all tests, both being synchronized to avoid cross-talking phenomenon.

Just before each experiment, the fishway flow gate was opened to achieve the desired water level and discharge flow (design conditions). Once established, the mesh at the upstream end of the staging area was removed and fish were allowed to ascend the fishway volitionally. Two homogenous groups of barbel per fishway did so, each trial lasting 24 hours (Table 2).

Water level and temperature (Orpheus Mini, OTT Hydromet GmbH) were monitored in both fish ladders throughout the day at 10-minute intervals. 


\section{Data analysis}

\section{Onset of movement:}

In these trials, fish were able to make several ascents. Once fish reached the upper limit of the fishway (closed with a mesh) or their maximum ascent distance (fatigue), they usually descended to the resting pool, from where they could try to ascend again, thus accounting for several attempts. Attempts were not considered valid unless the fish was detected at antenna 2 so as to separate exploratory movements from ascent movements. The last detection at antenna 1 was considered as the start time of the attempt. Attempts where fish were detected at the antenna located at a height of $2.25 \mathrm{~m}$ were considered "successful"; otherwise, they were considered "failures".

\section{Motivation:}

Ascent motivation was analyzed in terms of two metrics: 1 ) whether or not barbels made some attempt, analyzed via the chi-square test of independence; and 2) the time since the beginning of the trial until the first attempt, which was quantified using survival analysis, employing the Kaplan-Meier test and Log-Rank non-parametric test. For this purpose, those fish that staged at least one attempt resulting in an uncensored observation and those fish without any attempt were included as censored observations with an attempt time equal to the duration of the trial.

\section{Ascent analysis}

Of those fish that staged attempts, ascent ability was analyzed using three additional metrics.

1) Success: the proportion of ascending fish that reached the uppermost antenna, analyzed via the chi-square test of independence. 2) Transit time: the time needed to travel between the lowest and the uppermost antenna. Turning and straight pools in SNBO were first compared using median comparison via the Kruskall-Wallis test and then analyzed using Cox Proportional Hazard regression (PROC PHREG for SAS) strata by attempt, assessing the influence of fishway type and fish length. 3) Prediction of transit time as a function of fish length and the likelihood of its occurrence, survival analysis based on regression models, fitted with PROC LIFEREG and "Predict" Macro for SAS (Allison, 2010). Covariates were not considered to vary over the time of the trials. In subsections 2 ) and 3), only successful attempts were considered and transit time was converted into minutes per meter of ascent height, the reference measure being the median and not the mean due to the non-normal distribution of the data. 
All statistical analyses were performed using $\mathrm{SAS}^{\circledR}$ (version 9.4) and Statgraphics Centurion (version XVI.II) software.

\section{Results and discussion}

Testing was carried out during the spawning season (between 2nd and 7th June, 2012), when barbel seemingly exhibit strong migratory activity in this area. Water temperature varied between 18.3 and $20.5{ }^{\circ} \mathrm{C}$, with no differences between experiments. The weather was stable, sunny and mild during trials.

Flow discharge in both fishways was steady and close to design conditions. Very similar volumetric energy dissipation was generated in both fishways (Table 1).

Results between two fish collections per fishway type were analyzed in a preliminary test, finding no significant differences between them in any of the fishways, neither in motivation nor in ascent parameters ( $p>0.265$ in all cases). Hence, both collections were merged for subsequent results.

Table 2. Sample size for the fish under study. Trial date: date and start time of trials, with a duration of 24 hours; Fishway: Vertical slot (VS) and submerged notches with bottom orifice (SNBO); Group: set of fish under study; Available: number of available fish; $\mathrm{FL}$ : mean Fork Length [minimum $\mathrm{FL}-$ maximum $\mathrm{FL}$ ] $(\mathrm{cm})$; $\mathrm{K}$ : mean $\pm \mathrm{SD}$ condition factor $=100 \cdot$ mass $\cdot \mathrm{FL}^{-3}\left(\mathrm{~g} \cdot \mathrm{cm}^{-3}\right)$. Attempting: total number of attempts (number of fish that staged attempts).

\begin{tabular}{|c|c|c|c|c|c|c|}
\hline Trial date & Fishway & Collection & Available & $\mathrm{FL}[\min -\mathrm{max}]^{*}$ & $\mathrm{~K}^{*}$ & Attempting \\
\hline $\begin{array}{c}6 / 2 / 2012 \\
18: 30 h\end{array}$ & VS & 1 & 41 & $17.9[11.0-24.0]$ & $1.51 \pm 0.18$ & $129(35)$ \\
\hline $\begin{array}{c}6 / 4 / 2012 \\
11: 00 \mathrm{~h}\end{array}$ & SNBO & 2 & 41 & $17.3[11.2-34.0]$ & $1.49 \pm 0.19$ & $61(23)$ \\
\hline $\begin{array}{c}6 / 5 / 2012 \\
14: 30 \mathrm{~h}\end{array}$ & SNBO & 1 & 38 & $17.8[11.0-24.0]$ & $1.49 \pm 0.20$ & 56 (19) \\
\hline $\begin{array}{c}6 / 6 / 2012 \\
20: 30 \mathrm{~h}\end{array}$ & VS & 2 & 33 & $16.8[11.2-27.7]$ & $1.52 \pm 0.19$ & $41(6)$ \\
\hline
\end{tabular}

\footnotetext{
*There were no significance differences between fishways and/or collections
} 


\section{Motivation analysis}

1) Analyzing the number of fish that staged some attempt versus the total number of available fish, there were no differences between fishway types (VS $=55.4 \%$ and SNBO $=53.2 \% ; p=$ $0.781)$.

2) Regarding time from the beginning of the trial until the first attempt, no differences were found between the two types of fishway (median time: VS $=0.49 \mathrm{~min}$ and SNBO $=64 \mathrm{~min} ; \mathrm{p}=$ $0.557)$.

According to these results, motivation may be considered similar for both fishway designs.

\section{Ascent analysis}

Success was similar between fishways for the first attempt (VS $=92.7 \%$ and SNBO $=90.5 \% ; p=$ 0.718 ) and when taking into account all the attempts (VS $=95.6 \%$ and SNBO $=93.7 \% ; p=$ $0.532)$.

2) As the turning pool may affect and delay transit time (Thiem et al., 2011; Silva et al., 2015; Marriner, 2014, 2016; Nijssen et al., 2015), a comparison between this pool and the straight sections was first carried out for successful attempts in SNBO. There were significant differences between the two (median time for a height of 1 meter: turning pool $=8.2 \mathrm{~min}$ and straight sections $=4.2 \mathrm{~min} ; \mathrm{p}<0.001)$. Subsequently, to compare both fishway types in terms of transit time, only straight sections in SNBO were considered, the ascent being faster in this latter design (median time for a height of 1 meter: VS $=6.1 \mathrm{~min}$ and SNBO $=4.2 \mathrm{~min} ; \mathrm{p}=$ $0.040)$.

In any case, these ascent values for barbel in VS and SNBO were lower than for the same species and type of fishways with higher volumetric energy dissipation. For instance, barbel needed $18.9 \mathrm{~min} / \mathrm{m}$ in a straight VS fishway with $185 \mathrm{~W} / \mathrm{m}^{3}$ (slope $8 \%$; drop between pools 0.2 m) (Sanz-Ronda et al., 2016) and $22.3 \mathrm{~min} / \mathrm{m}$ in a SNBO fishway with $181 \mathrm{~W} / \mathrm{m}^{3}$ and one turning pool (slope 8.8 \%, drop between pools 0.25 m) (Bravo-Córdoba et al., 2016 in rev.). This inverse relationship between volumetric energy dissipation and passage efficiency has been reported in the scientific literature (Santos et al., 2012; Fouche et al., 2013), volumetric energy dissipation probably being the easiest and one of the most common parameters used by fishway engineers to indicate how good the structure is for fish ascent (Kynard et al., 2011). 
The possibility of fatigue or learning during the ascent was taken into account, but no pattern was observed between antennas to support either hypothesis.

Fish length, on the other hand, was found to be an influential covariate, showing a negative correlation with transit time for VS $(p=0.0037)$, but not for SNBO $(p=0.387)$, smaller individuals seemingly needing more time to ascend VS. A number of studies have reported a similar relationship between barbel length and swimming speed (Silva, 2011; Sanz-Ronda, 2015), though others such as Thiem et al. (2011) did not find this relationship in the case of lake sturgeon in VS.

3) For VS, a predictive model of the proportion of fish ascending as a function of fish length was calculated (transit time per meter of height). The best-fitted model (Akaike's Information Criterion) was log-logistic regression (Fig. 2). Based on this model, the effect could be expressed approximately as transit time reduced by $(\exp (-0.0646)-1)=6.2 \%$ per $\mathrm{cm}$ increased in fork length. Despite size differences between the $10^{\text {th }}$ and $90^{\text {th }}$ percentiles not being very large (approximately $8 \mathrm{~cm}$ ), the maximum difference in the sample was about $23 \mathrm{~cm}$. Thus, the influence of fish length was considered important in ascent time. Studying the same species and similar sizes, Sanz-Ronda et al. (2015) likewise found a superior swimming endurance in larger individuals.

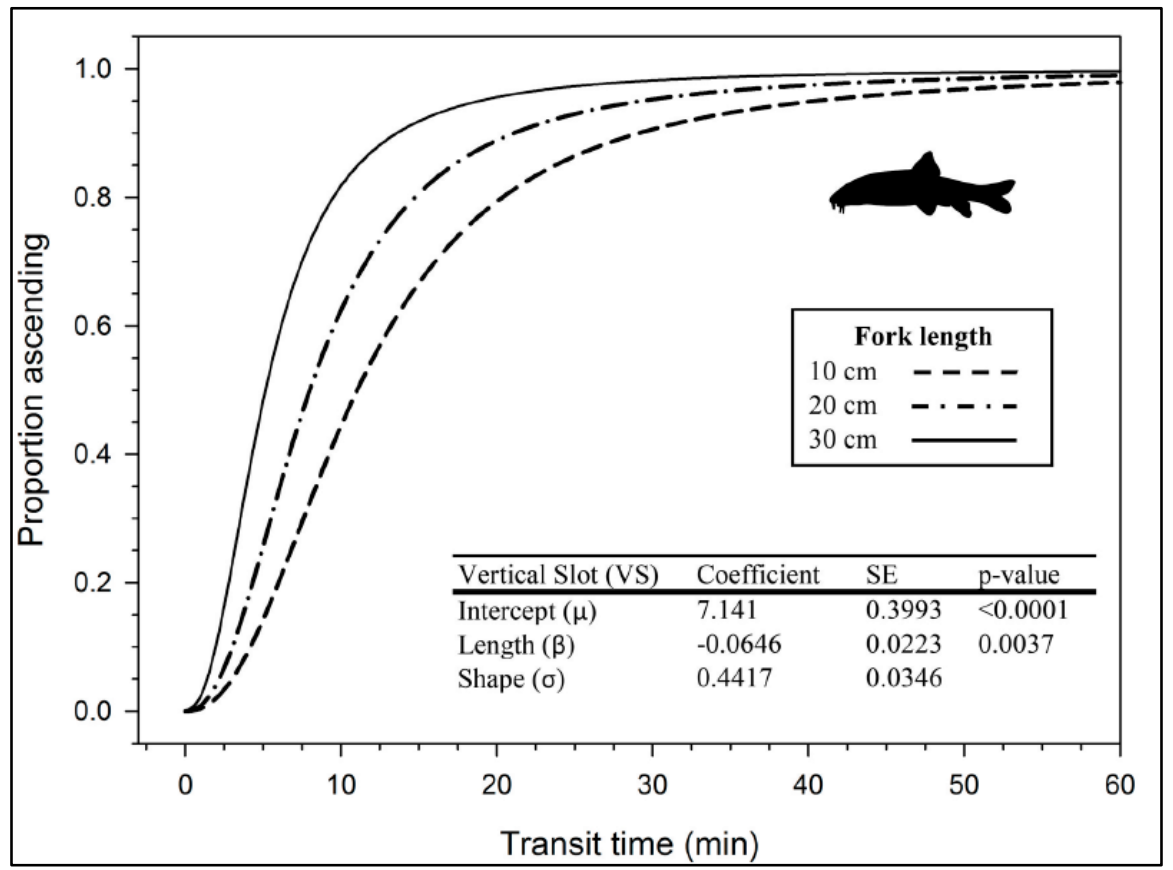

Fig. 2. Vertical slot predictive model (log-logistic) for the proportion of fish ascending ( $1 \mathrm{~m}$ of height exceeded) at a given transit time as a function of fish length. 


\section{Conclusions}

The contribution of this study is to provide criteria for the selection and design of fishways and, in particular, for the Mediterranean barbel: Luciobarbus bocagei, as numerous structures of these types are soon to be built in their native area. Based on the results presented here, both VS and SNBO have a similar good performance for a wide range of fish lengths under the trial design assumptions. However, ascent times were slightly faster for SNBO, though assuming no important migration delays in both types. Turning pools must be considered to have an effect in this species and further research is needed regarding their influence. Ascent ability can be modeled, constituting an interesting tool for future comparisons between other fishway types or target species and sizes.

\section{Acknowledgments}

Francisco Javier Bravo Córdoba performed this research under the support of a Ph.D. grant from the University of Valladolid PIF-UVa 2011. We specifically thank Juan Carlos Romeral de la Puente (SAVASA) for letting us use his installations and the GEA-Ecohidráulica research group for their help during fieldwork.

\section{References}

Allison P.D. 2010. Survival analysis using SAS: a practical guide. Sas Institute.

Aparicio E., Pintor C., Durán C., and Carmona Catot G. 2012. Fish passage assessment the most downstream barrier of the Ebro River (NE Iberian Peninsula). Limnetica, 31 (1), 37-46.

Baudoin J. M., Burgun V., Chanseau M., Larinier M., Ovidi M., Sremski W. and Voegtle, B. 2015. Assessing the passage of obstacles by fish. Concepts, design and application. Onema. 200 pp.

Bravo-Córdoba F.J., Sanz-Ronda F.J., Ruiz-Legazpi J., Celestino I. and Makrakis S. 2016. Fishway with two entrance branches: understanding its performance for Iberian barbel, luciobarbus bocagei (Steindachner, 1864). In rev.

Clay, C. H. 1995. Design of Fishways and Other Fish Facilities. Lewis Publishers. Ann Arbor, MI. 
Doadrio I., Perea S., Garzón-Heydt P. and Y González J., 2011. Ictiofauna continental española. Bases para su seguimiento. Ministerio de Medio Ambiente y Medio Rural y Marino, Centro de Publicaciones.

Elvira B., Almodóvar A. and Nicola G. G., 1998. Impacto de las obras hidráulicas en la ictiofauna: Dispositivos de paso para peces en las presas de España, Organismo Autónomo Parques Nacionales, Madrid.

Fouché P. S. O., and Heath R. G. 2013. Functionality evaluation of the xikundu fishway, luvuvhu river, south africa. African Journal of Aquatic Science, 38(1), 69-84

Fuentes-Pérez J.F., Sanz-Ronda F.J., de Azagra Paredes A.M., and García-Vega A. 2014. Modeling Water-Depth Distribution in Vertical-Slot Fishways under Uniform and Nonuniform Scenarios. Journal of Hydraulic Engineering.

Fuentes-Pérez J. F., Sanz-Ronda F. J., de Azagra A. M., and García-Vega A. 2016. Non-uniform hydraulic behavior of pool-weir fishways: A tool to optimize its design and performance. Ecological Engineering, 86, 5-12.

Kynard B., Pugh D. and Parker, T. 2011. Passage and behaviour of cultured Lake Sturgeon in a prototype side-baffle fish ladder: I. Ladder hydraulics and fish ascent. Journal of Applied Ichthyology, 27(2), 77-88.

Larinier, M. 2002. Pool fishways, pre-barrages and natural bypass channels. Bulletin Français de la Pêche et de la Pisciculture, 364(suppl), 54-82.

Marriner B. A., Baki A. B. M., Zhu D. Z., Thiem J. D., Cooke S. J., and Katopodis C. 2014. Field and numerical assessment of turning pool hydraulics in a vertical slot fishway. Ecological Engineering, 63, 88-101.

Marriner B. A., Baki A. B., Zhu D. Z., Cooke S. J., and Katopodis C. 2016. The hydraulics of a vertical slot fishway: A case study on the multi-species Vianney-Legendre fishway in Quebec, Canada. Ecological Engineering, 90, 190-202.

Nijssen D., Pitsch M., Herbst M. and Mahl L. 2015. Ethohydraulics in Turbulence: Fish Behaviour in Turning Pools. International Conference on Engineering and Ecohydrology for Fish Passage. Paper 10. 
Ordeix M., Pou-Rovira Q., Bardina M., Munné A., Solà, C. Casamitjana, A., and Sellarès N. 2011. Fish pass assessment in the rivers of Catalonia (NE Iberian Peninsula). A case study of weirs associated with hydropower plants and gauging stations. Limnetica, 30(2), 0405-426.

Rocaspana-Jové R., Aparicio-Manau E. and Palau-Ibars A. 2012. Análisis del uso, la eficiencia y la necesidad del paso para peces en el azud de Salinas (río Cinca, Huesca). Informe Técnico. Dirección de Medio Ambiente y Desarrollo Sostenible, Endesa.

Rosgen D. L. and Silvey H. L., 1996. Applied river morphology, Wildland Hydrology Pagosa Springs, Colorado.

Sanz-Ronda F. J., Ruiz-Legazpi J., Bravo-Córdoba F. J., Makrakis S. and Castro-Santos T., 2015. Sprinting performance of two Iberian fish: Luciobarbus bocagei and Pseudochondrostoma duriense in an open channel flume. Ecological Engineering., 83, 61-70.

Sanz-Ronda F. J., Bravo-Córdoba F. J., Fuentes-Pérez J. F., \& Castro-Santos T. 2016. Ascent ability of brown trout, Salmo trutta, and two Iberian cyprinids- Iberian barbel, Luciobarbus bocagei, and northern straight-mouth nase, Pseudochondrostoma duriense- in a vertical slot fishway. Knowledge and Management of Aquatic Ecosystems., 417, 10.

Santos J. M., Silva A., Katopodis C., Pinheiro P., Pinheiro A., Bochechas J. and Ferreira M. T. 2012. Ecohydraulics of pool-type fishways: getting past the barriers. Ecological Engineering, 48 , 38-50.

Silva A. T., Santos J. M., Ferreira M. T., Pinheiro A. N. and Katopodis C. 2011. Effects of water velocity and turbulence on the behaviour of Iberian barbel (Luciobarbus bocagei, Steindachner 1864) in an experimental pool-type fishway. River Research and Applications, 27(3), 360-373.

Silva A. T., Hatry C., Thiem J. D., Gutowsky L. F., Hatin D., Zhu D. Z., Dawson J.W., Katopodis C. and Cooke, S. J. 2015. Behaviour and locomotor activity of a migratory catostomid during fishway passage. PloS One, 10(4), e0123051.

Thiem J. D., Binder T. R., Dawson J. W., Dumont P., Hatin D., Katopodis C., Zhu D.Z. and Cooke S. J. 2011. Behaviour and passage success of upriver-migrating lake sturgeon Acipenser fulvescens in a vertical slot fishway on the Richelieu River, Quebec, Canada. Endangered Species Research, 15(1), 1-11. 


\section{RESULTADOS III: Fishway with two entrance branches: understanding its performance for Iberian barbel, Luciobarbus bocagei (Steindachner, 1864)}

Francisco Javier BRAVO-CÓRDOBA ${ }^{* 1}$, Francisco Javier SANZ-RONDA ${ }^{1}$, Jorge RUIZ-LEGAZPI ${ }^{1}$, Leandro FERNANDES-CELESTINO ${ }^{2}$ \& Sergio MAKRAKIS ${ }^{2}$

En fase de revisión en la revista Hydrobiologia.

${ }^{1}$ U. D. de Hidráulica e Hidrología.

Grupo de Ecohidráulica Aplicada (GEA-ecohidraulica.org)

Departamento de Ingeniería Agrícola y Forestal.

E.T.S.II.AA. Universidad de Valladolid.

Avda. Madrid, 44; 34004 Palencia (Spain)

francisco.bravo@iaf.uva.es

+34979108358 (Ph.)

+34979108302(Fax)

${ }^{2}$ Universidade Estadual Do Oeste do Parana.

Rua da Faculdade, 645 Toledo-Paraná, (Brasil) 


\section{Abstract}

Many fish passes have been built and improved on the Iberian Peninsula in recent years. To ensure their proper operation, it is essential to carry out an evaluation, both of their biological and hydraulic aspects.

This study analyzes the performance of a pool and weir fishway with two branches or ways of access for fish: a turbine channel and a bypassed reach. Both the most relevant hydraulic values (flow and volumetric energy dissipation) and biological parameters (location [and its relationship with environmental variables], entrance and passage) were measured. Research focused on the Iberian barbel, Luciobarbus bocagei (Steindachner, 1864), at a hydropower plant situated on the Duero River (province of Valladolid, Spain), with fish captured downstream and upstream of the fishway. Biological assessment was conducted between May and September using PIT-tag technology.

Some environmental covariates, namely flow discharge, water temperature and atmospheric pressure, were important for fish movement, although differences between branches were observed. There were no preferences between path routes, despite the fact that the main discharge was concentrated in the turbine channel. Ascent success and transit time in the fishway were similar between branches. Origin of fish was a relevant factor, with fish captured upstream being found to be more motivated.

This fishway design could be a good solution for increasing fish passage and reducing costs compared to building two fishways.

Keywords: Fish ladder, cyprinid, transit time, competing risk, time-dependent covariates

\section{Introduction}

The potamodromous fish fauna of the Iberian Peninsula is mostly composed of endemic rheophylic cyprinids. One of the most common among these is the Iberian barbel (Luciobarbus bocagei Steindachner, hereafter referred to as 'barbel') (Doadrio, 2001). This species occupies a variety of riverine habitats, ranging from floodplains to headwaters, and plays an important role in trophic interactions within its ecosystems (Collares-Pereira et al., 1996). 
Like many cyprinids, barbel ascend from deep, slow flowing river reaches to shallower, faster flowing waters to spawn, largely in spring (migration movements from February to July, spawning being between May and June; Lobón-Cerviá and Fernández-Delgado, 1984; Doadrio et al., 2011). The range of these movements is related to hydraulic habitat diversity, being smaller in heterogeneous environments (Lucas et al., 2001; Leeuw and Winter, 2008; Britton and Pegg, 2011). Moreover, individual factors are relevant. Thus, some fish are more static than others within the same species and/or during the same reproductive period (Ovidio et al., 2007; Chapman et al., 2012; Alexandre et al., 2015). The underlying causes are associated with many factors (Lucas et al., 2001), water temperature being one of the major triggers of spawning movements for Iberian barbel (Rodríguez-Ruiz and Granado-Lorencio, 1992; Santos et al., 2008). However, flow discharge (Santos et al., 2005) and photoperiod (Britton et al., 2011) sometimes also play an important role.

Barriers to movement like weirs, gauging stations or culverts block access to essential habitat and are among the principal threats affecting these communities (Sanz-Ronda et al., 2010; Makrakis et al., 2012; Branco et al., 2014; Bravo-Córdoba et al., 2014). One of the most popular solutions to this problem employed on the Iberian Peninsula comprises pool and weir fishways. In many cases, however, design criteria are not based on the specific features of cyprinids (Mallen-Cooper and Brand, 2007; Branco et al., 2013), mainly due to the lack of scientific information, which is even more pronounced for endemic cyprinids (Sanz-Ronda et al., 2016). Of the few fishway ascent studies that have been carried out on these species, the majority have been conducted in the laboratory and have focused on hydraulic parameters (Silva et al., 2009; Silva et al., 2012; Branco et al., 2013; Santos et al., 2014). As Thiem et al., (2013) point out, the relationship between laboratory results and field conditions is not well established, also often not researching in location and entrance of fishways. Hence, the need for rigorous fish ladder assessment, taking attraction/location, entrance and passage into consideration, becomes particularly important (Castro-Santos, 2012; Castro-Santos et al., 2009; Castro-Santos and Haro, 2010; Castro-Santos and Perry, 2012; Noonan et al., 2012; Cooke and Hinch. 2013; Benitez et al., 2015).

Furthermore, the implementation of solutions for fish migration often exhibits certain peculiarities. A common situation is the existence of several routes to approach the obstacle. Fish can choose more than one way for their movement, depending on physicochemical parameters. These include water quality, temperature, odor, etc. (Lucas et al., 1996; Larinier et 
al., 2002; Rakowitz et al., 2008; Prchalova et al., 2011; Keefer and Caudill, 2015), and/or hydraulic variables, such as water flow, water velocity, depth, and turbulence (Santos et al., 2005; Slavik et al., 2009; Sanz Ronda et al., 2015; Kemp, 2012; Lacey et al., 2012; Cardoso, 2014). It is therefore usually difficult to determine the best location for the fishway entrance or whether there is a need to build more than one fish pass. An interesting option is one fishway with more than one branch for the entrance. This solution is still not very commonplace, but it can be adapted, for instance, to dams with the powerhouse just at the base of the weir (BravoCórdoba et al., 2015) and a turbine restitution channel. This outlet channel usually converges with the main stem within $500 \mathrm{~m}$ downstream from the dam. Hence, two routes for fish migration are possible: a bypassed reach (under normal conditions, this runs the ecological flow) and a restitution channel. Almost half of the small hydropower plants on Spain's Duero River belong to this type of fishway (CHD, 2013).

This is the case that concerns us here, namely a fishway with two branches. Data on the design and performance of fish ladders with more than one way of access are scarce. There are some examples of technical reports (Turner et al., 1983; Bjorn et al., 1994; Keefer et al., 1997, 2007; Stansell and Beck, 2002; Brown et al., 2002; Johnson et al., 2010; Clabough et al., 2011) and few papers about these solutions (Bunt et al., 1999; Reischel and Bjornn, 2003; Naughton et al., 2007). Many of these papers analyze dams with more than one fishway (Turner et al., 1983; Keefer et al., 1997; Bunt et al., 1999). The most similar to the present paper are those which have studied the Bradford Island fishway at the Bonneville Dam, on the Columbia River (Brown et al., 2002; Stansell and Beck, 2002; Reischell and Bjornn, 2003; Johnson et al., 2010; Keefer et al., 2013, 2014). Studying the routes, the path preferences and possible problems that may arise can be established, defined by Keefer et al. (2013) as a fishway passage bottleneck.

The purpose of this paper is thus to evaluate the passage performance of Iberian barbel in a fishway with two branches for fish entrance (a novel fishway design in Spain) and the main related environmental variables. 


\section{Methods}

\section{Study site}

The experiments were carried out on the Duero River, in the village of Peñafiel (province of Valladolid, northwest Spain; 42 37' 25.21 "N; 4 10' 47.77" W; Figure 1). The river there drains a watershed of $12220 \mathrm{~km}^{2}$ with a mean annual discharge of around $24.4 \mathrm{~m}^{3} / \mathrm{s}$ (data from the Quintanilla de Onésimo gauging station; $17 \mathrm{~km}$ downstream from the fishway location).

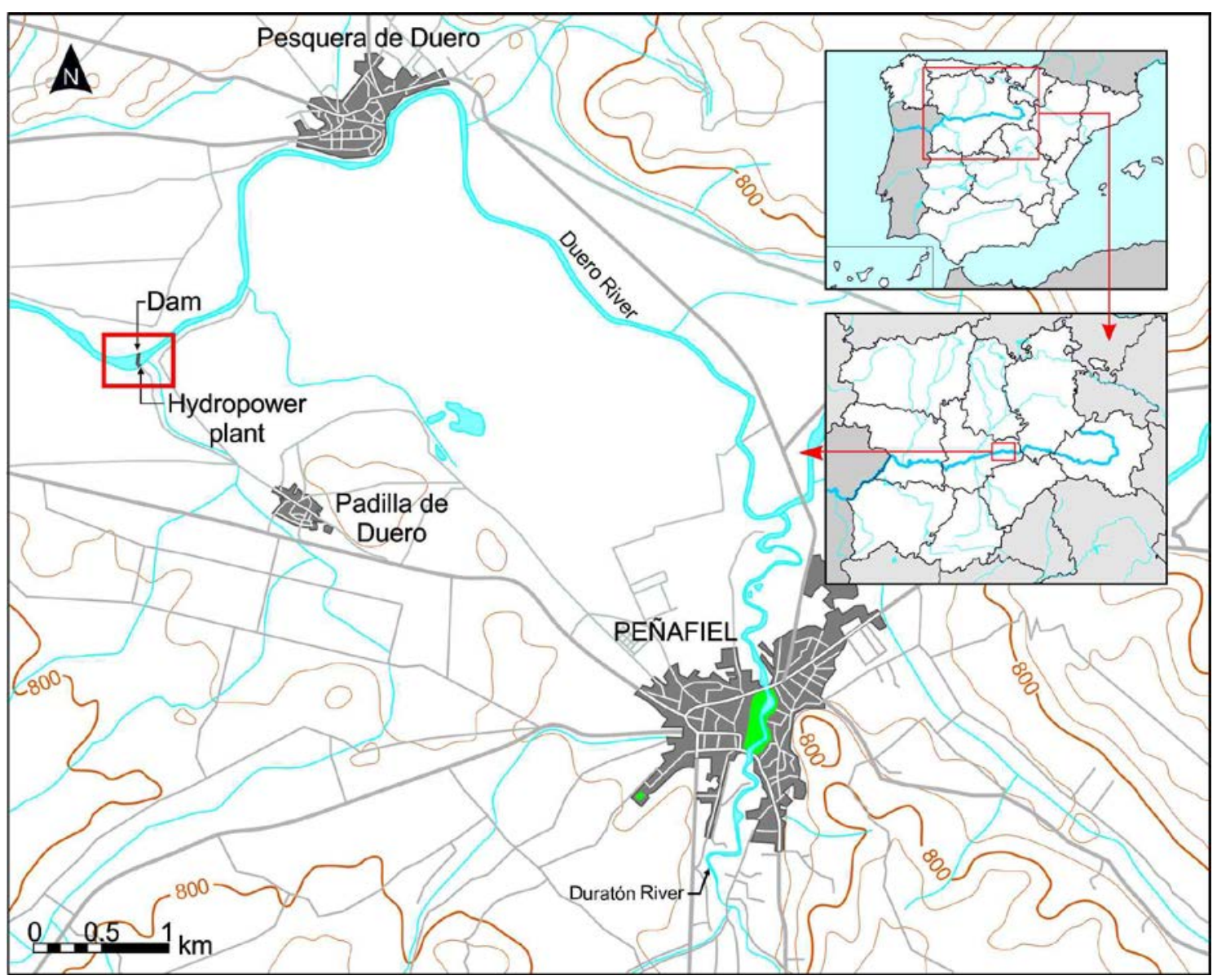

Figure 1. Study site location: Duero River, Region of Castilla y León (northwest Spain).

The reach under study belongs to the epipotamon area (Illies and Botosaneanu, 1963) with an average altitude of around 740 meters above sea level. The area corresponds to a C4 - C6 category (gravel and silt-clay streambed of moderate sinuosity with a slope of $0.001-0.02 \mathrm{~m} / \mathrm{m}$; Rosgen and Silvey, 1996). The most abundant native fish species are Iberian barbel and northern straight-mouth nase (Pseudochondrosoma duriense), both of which are potamodromous fish. Exotic fish are abundant, predominantly Alburnus alburnus, Carassius auratus and Cyprinus carpio. 
There is a hydropower plant in this area with an associated weir of $3.9 \mathrm{~m}$ in height between upstream and downstream water levels. The powerhouse is at the base of the dam, with a tailrace channel downstream of the dam of about $140 \mathrm{~m}$ in length. Hence, the river is divided in two branches separated by an island: a deep, narrow tailrace/turbine channel and a wider, shallower natural/bypassed channel (Figure 2). Ecological flow is $2 \mathrm{~m}^{3} / \mathrm{s}$ and runs off along the $100 \mathrm{~m}$ wide dam and therefore runs through the island complex of the bypassed reach (several channels of 3 to $10 \mathrm{~m}$ wide and 0.1 to $1 \mathrm{~m}$ deep, with suitable areas for spawning of rheophilic cyprinids). The remaining river flow passes through the turbines (up to a maximum of $36 \mathrm{~m}^{3} / \mathrm{s}$ ), draining into the natural river through the turbine channel (16 to $22 \mathrm{~m}$ wide and 2.5 to $3 \mathrm{~m}$ deep).

\section{Fishway}

In order to mitigate the habitat fragmentation caused by the dam, a technical fishway (pool and weir with surface submerged notches and bottom orifices) was built in 2014 on the left bank of the dam (Figure 2). 


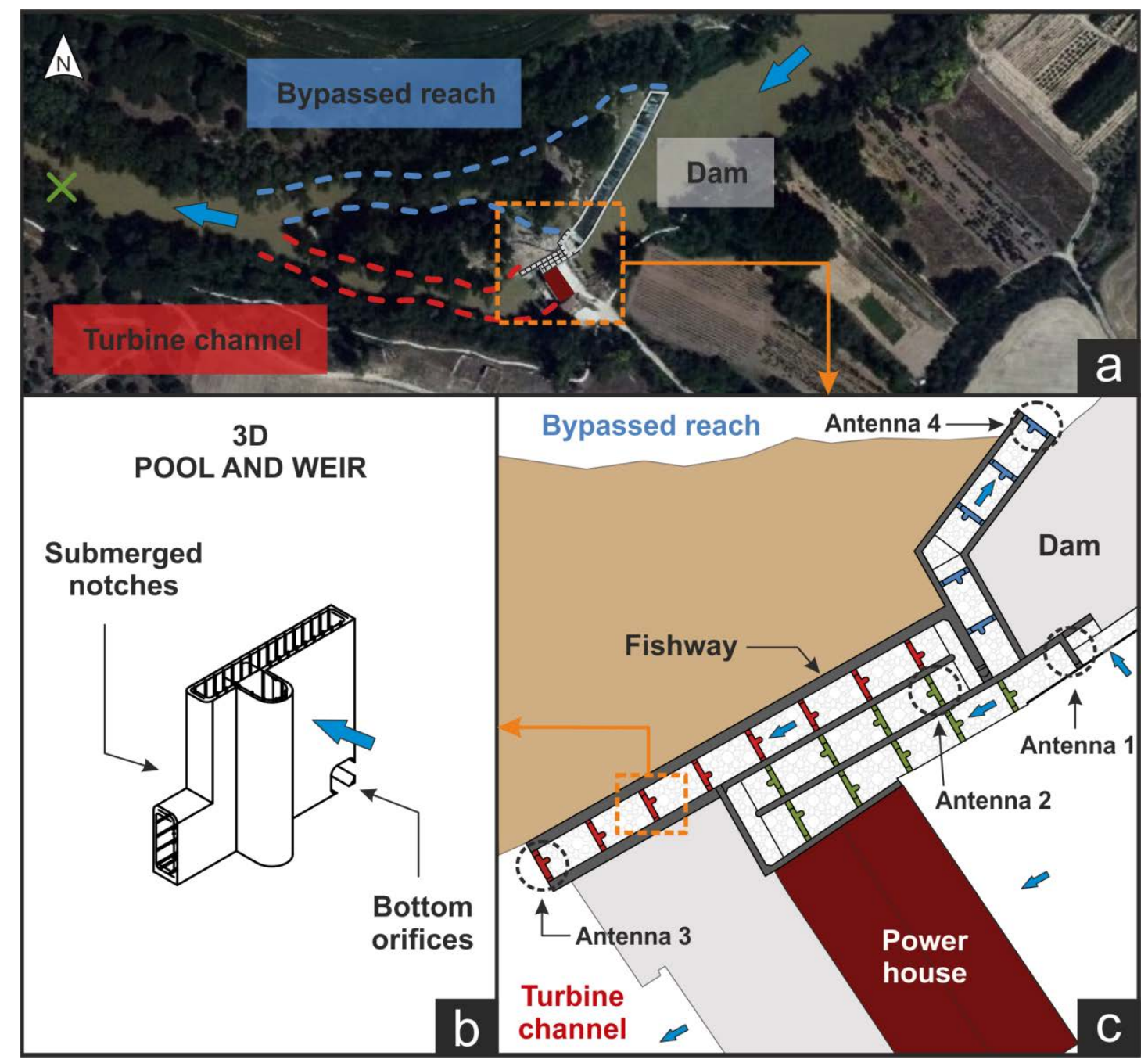

Figure 2. a) Plan view and outline of the study area (photograph modified from ${ }^{\odot}$ Instituto Geográfico Nacional de España, retrieved 26 January, 2016. http://www.ign.es); $\times$ : Fish released point. b) 3-D fishway weir scheme. c) Plan view of the fishway, location of antennas and the different sections. Blue arrows indicate flow direction.

The fish ladder has three different sections: two entrances from the bypassed and turbine channels that come together in a common branch of the fish exit (Table 1). The design flow is $0.395 \mathrm{~m}^{3} / \mathrm{s}$ and the elevation gain is approximately $4.40 \mathrm{~m}$ in the turbine channel route and $3.90 \mathrm{~m}$ in the bypassed reach route. The bottom of the structure is covered with substrate from the riverbed to increase roughness (protruding from the floor approximately $10 \mathrm{~cm}$ ). The uppermost pool (fishway exit) has a sluice gate that is used to regulate flow inside the fishway. The bypassed reach fishway entrance is supported by an additional flow of $0.15 \mathrm{~m}^{3} / \mathrm{s}$ to attract fish.

Water level and temperature were monitored (EL-USB-1-PRO; Lascar Electronics Limited) in the fishway throughout the study period at 15 minute intervals. 
Table 1. Geometrical characteristics of the fishway. Volumetric Energy Dissipation as: median and InterQuartile Range (IQR).

\begin{tabular}{|c|c|c|c|}
\hline & Main stem & $\begin{array}{c}\text { Turbine channel } \\
\text { branch }\end{array}$ & $\begin{array}{l}\text { Bypassed reach } \\
\text { branch }\end{array}$ \\
\hline Slope & $8.8 \%$ & $8.8 \%$ & $9.8 \%$ \\
\hline Number of pools & 9 & 9 & 5 \\
\hline $\begin{array}{l}\text { Height drop between } \\
\text { pools }\end{array}$ & $0.25 \mathrm{~m}$ & $0.25 \mathrm{~m}^{*}$ & $0.25 \mathrm{~m}^{*}$ \\
\hline $\begin{array}{l}\text { Pool dimension } \\
\text { (length } x \text { width) }\end{array}$ & $2.6 \times 1.6 \mathrm{~m}$ & $2.6 \times 1.6 \mathrm{~m}$ & $2.3 \times 1.5 \mathrm{~m}$ \\
\hline Width of the notches & $0.40 \mathrm{~m}$ & $0.25 \mathrm{~m}$ & $0.20 \mathrm{~m}$ \\
\hline Bottom orifices & $0.25 \times 0.25 \mathrm{~m}$ & $0.15 \times 0.15 \mathrm{~m}$ & $0.15 \times 0.15 \mathrm{~m}$ \\
\hline Flow discharge** & $0.395 \mathrm{~m}^{3} / \mathrm{s}$ & $0.236 \mathrm{~m}^{3} / \mathrm{s}$ & $0.159 \mathrm{~m}^{3} / \mathrm{s}$ \\
\hline $\begin{array}{l}\text { Volumetric Energy } \\
\text { Dissipation }\end{array}$ & $182(169-201) \mathrm{W} / \mathrm{m}^{3}$ & $49(21-87) \mathrm{W} / \mathrm{m}^{3}{ }^{*}$ & $62(57-67) \mathrm{W} / \mathrm{m}^{3} *$ \\
\hline
\end{tabular}

* Depending on downstream water levels, these values could be lower or higher.

**Actual flow discharge obtained through dilution gauging, using Rhodamine WT, on previous trial dates.

\section{Fish testing}

We used a passive integrated transponder (PIT)-tag and antenna system to study fish passage (Castro-Santos et al., 1996, Franklin et al., 2012).

Fish were caught at two places: downstream of the weir in the bypassed reach (between the restitution channel and the base of the dam) by electrofishing (Erreka model; $2200 \mathrm{~W}, 5 \mathrm{~A}$ ) and $54 \mathrm{~km}$ upstream of the study site, in the same river, by trapping in a fishway. Within 2 hours of capture, fish were transported to the tagging area in $100 \mathrm{~L}$ aerated tanks. All fish (197 barbels) were tagged with PIT-tags (Half-duplex tags measuring $23 \mathrm{~mm}$ long by $3.85 \mathrm{~mm}$ diameter, $0.6 \mathrm{~g}$ weight: TIRIS model RI-TRP-WRHP; Texas Instruments, Dallas, Texas, USA). They were anaesthetized with a solution of $0.10 \mathrm{~g} / \mathrm{L}$ MS-222 (Tricaine methanesulfonate) and tagged intraperitoneally by making an incision posterior to the left pectoral fin and gently inserting the tag into the peritoneal cavity (Castro-Santos and Vono, 2013). No fish died during the marking process. This method has been shown to have negligible effects on the growth, survival, and behavior of many species (Ficke et al., 2012, Ostrand et al., 2011). 
Fish were then transferred to the staging area in $300 \mathrm{~L}$ aerated tanks, where they recovered and acclimated to the new environment. After the recovery period, fish were released $0.5 \mathrm{~km}$ downstream of the junction of the bypassed reach and turbine channel, on the left bank of the river, allowing them to choose their way and ascend the fishway volitionally.

Testing was carried out during and after the spawning season over a period of 100 days (from May 30 until September 8 ), when barbel seemingly exhibits strong migratory activity in this area. Four antennas were built into the fishway for monitoring purposes. Antennas were placed at the two fish entrances (antennas 3 and 4), at the meeting point of the two branches (antenna 2), and at the fish exit (antenna 1) (Figure 2). Each antenna was connected to a dedicated reader (ORFID ${ }^{\circ}$ Half Duplex reader with a Multiplexer antenna), programmed to query the antennas at $14 \mathrm{~Hz}$ ( $3.5 \mathrm{~Hz}$ or 0.29 s per antenna).

\section{Data analysis}

\section{Fishway location}

Location was quantified using three methods:

1) Whether or not each fish located the fish pass, evaluating the effects of fish source and branch location (analyzed using a logistic regression and pairwise comparison using the chisquare test of independence).

2) Time spent since release to location, evaluating the effects of fish source and branch location (analyzed via the Mann-Whitney test for median comparison and a one-way ANOVA test for mean comparison). The proportion of fish location along a timeline was obtained using the extended Cox proportional hazard regression model with competing risks (Castro-Santos and Haro, 2003; Allison, 2010; Kleinbaum and Klein, 2012). As the data did not meet the assumption of proportionality, it was calculated via a macro for the SAS software called CIF which compares cumulative incidence functions of survival data (Lin et al., 2012). These functions implement the cumulative probability that an event happens over time.

3) How fish located either branch as a function of the main considered environmental variables (water temperature, air pressure and flow discharge through the river and for each branch). This was determined using the extended Cox proportional hazard regression model with time dependent covariates for survival data (Kleinbaum and Klein, 2012; Powell and Bagnell 2012) 
via a macro for the SAS software called PSHREG (Kohl et al., 2015). As fish were released on different days, a counting process was employed. Due to the presence of repeated events on some dates, Efron's method of handling ties in data was implemented. Automatic backward selection was performed $(\alpha=0.10)$ to select the significant covariates. The covariates included in the model were the following:

Q: mean daily flow discharge through the river.

$Q_{\text {turbine }}:$ mean daily flow discharge through the turbine channel.

$\mathrm{Q}_{\text {bypassed: }}$ mean daily flow discharge through the bypassed reach.

T: mean daily water temperature.

P: mean daily atmospheric pressure.

$\mathrm{Q}_{\text {bypassed /turbine: flow rate between flow discharge through the bypassed reach and turbine }}$ channel.

$\mathrm{Q}_{\mathrm{d}-1}$ : mean daily flow discharge on the day before the event.

$\mathrm{Q}_{\mathrm{d}-2}$ : mean daily flow discharge on two days before the event.

$\Delta Q$ : variation of mean daily flow discharge between previous and current day of event.

$\Delta \mathrm{Q}_{\mathrm{d}-1}:$ variation of mean daily flow discharge between two and one day before the event.

\section{$\underline{\text { Passage analysis }}$}

Of those fish that staged attempts, passage performance was analyzed using two additional metrics: 1) Success: the proportion of ascending fish that reached the uppermost antenna (statistically analyzed with logistic regression), and 2) transit time: the minimum time needed to travel between the lowest and uppermost antenna, represented by the Kaplan-Meier method and analyzed using the Log-Rank non-parametric test (Mantel, 1966). Median comparisons were performed using the Mann-Whitney test and mean analysis via a one-way ANOVA with the multiple-range Tukey's HSD test. Time was relativized per meter of height exceeded, thus facilitating the comparison between branches or between fishways in future studies. 
All statistical analyses were performed using SAS (version 9.4) and Stathgraphics Centurion (version XVI.II) software.

\section{Results}

Barbels were captured at two different locations, on four different days (Table 2). Water temperature varied during the experiment between 15.4 and $23.0{ }^{\circ} \mathrm{C}$.

Table 2. Sample sizes for fish under study (fish that were PIT tagged). The capture date coincides with the release date; Fish source: location/origin of fish sampling; Available: number of available fish; FL: mean fork length \pm SE; Attempting: number of fish that staged attempts; —: no fish sampling was performed.

\begin{tabular}{lccccc}
\hline Capture date & Fish source & Available & FL (mm) & Attempting & Success \\
\hline $30 / 5 / 2014$ & Downstream & 54 & $388 \pm 12$ & 2 & 0 \\
& Upstream & 35 & $171 \pm 5$ & 19 & 15 \\
$9 / 6 / 2014$ & Downstream & 30 & $343 \pm 22$ & 4 & - \\
$11 / 6 / 2014$ & Upstream & - & - & - & - \\
& Downstream & - & - & 32 & - \\
$23 / 6 / 2014$ & Upstream & 50 & $172 \pm 4$ & - & 13 \\
\hline Total & Downstream & - & - & 19 & 1 \\
\hline & Upstream & 28 & $186 \pm 9$ & 6 & 57 \\
\hline
\end{tabular}

\section{Fishway location}

1) The first interesting result is related to the amount of fish that located the fish ladder. Overall, 57 barbels were detected (28.9\%). The log regression between location percentage and fish source showed significantly higher location $(P<0.001)$ by fish captured upstream $(62.5$ $\%)$ than by those captured downstream (7.1\%).

As regards the fish that located the fishway, the approach branch used is also of interest. No difference was found between the first approach and the selected entrance ( $45.6 \%$ via the bypassed reach and $54.4 \%$ via the turbine channel; $P=0.273$ ). 
2) There was no difference in the time since fish were released until they located the fishway between the source of fish for either the median or mean comparison (Table 3).

Table 3. Median and mean value for location time (in days; time since fish were released until location of fishway), separated by fish origin. The P-value of mean comparison refers to the log transformation. IQR: Interquartile Range; SE: Standard Error.

\begin{tabular}{ccc}
\hline Source & Median (IQR) & Mean (SE) \\
\hline Downstream $(\mathrm{N}=6)$ & $12.5(5.0-25.7)$ & $23.2( \pm 12.1)$ \\
Upstream $(\mathrm{N}=51)$ & $13.0(8.5-35.7)$ & $20.9( \pm 2.3)$ \\
P-value & 0.612 & 0.774 \\
\hline
\end{tabular}

Based on the way of access (branch selection), if the frequencies of location are represented along the timeline (Figure 3), the following is observed. Up to 40 days after release (about $85 \%$ of fish with attempts), fish that located the fishway via the bypassed reach spent less time on this movement than fish that opted for the turbine channel. Subsequently, however, the remaining fish took less time to locate the fish ladder via the turbine channel. Nonetheless, the cumulative functions of both branches are statistically similar (Gray's test for equality of cumulative incidence functions; $P=0.618$ ).

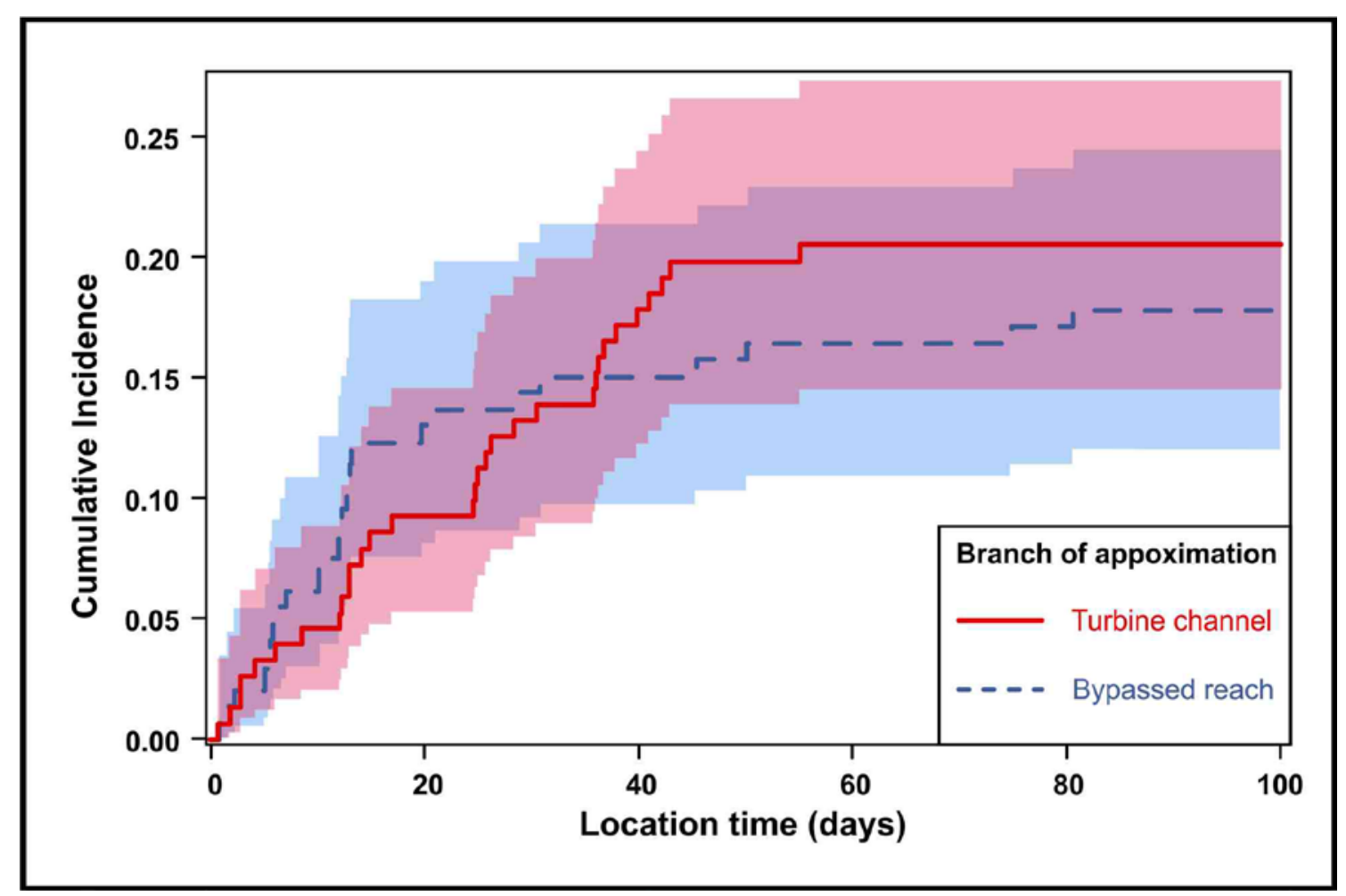


Figure 3. Cumulative Incidence Function (CIF) for location time (in days) since the fish were released, in their first attempt. Red dashed line: fish that located the fishway via the turbine channel. Blue line: fish that located the fishway via the bypassed reach. The confidence limit area is represented in the same color.

3) Analysis of branch location as a function of the main environmental variables may serve as an index of barbel behavior and/or as a guide. Figure 4 shows the chosen environmental variables (flow discharge per branch, water temperature and atmospheric pressure) along the timeline of the experiments. The number of first locations of individuals for each day is also represented.

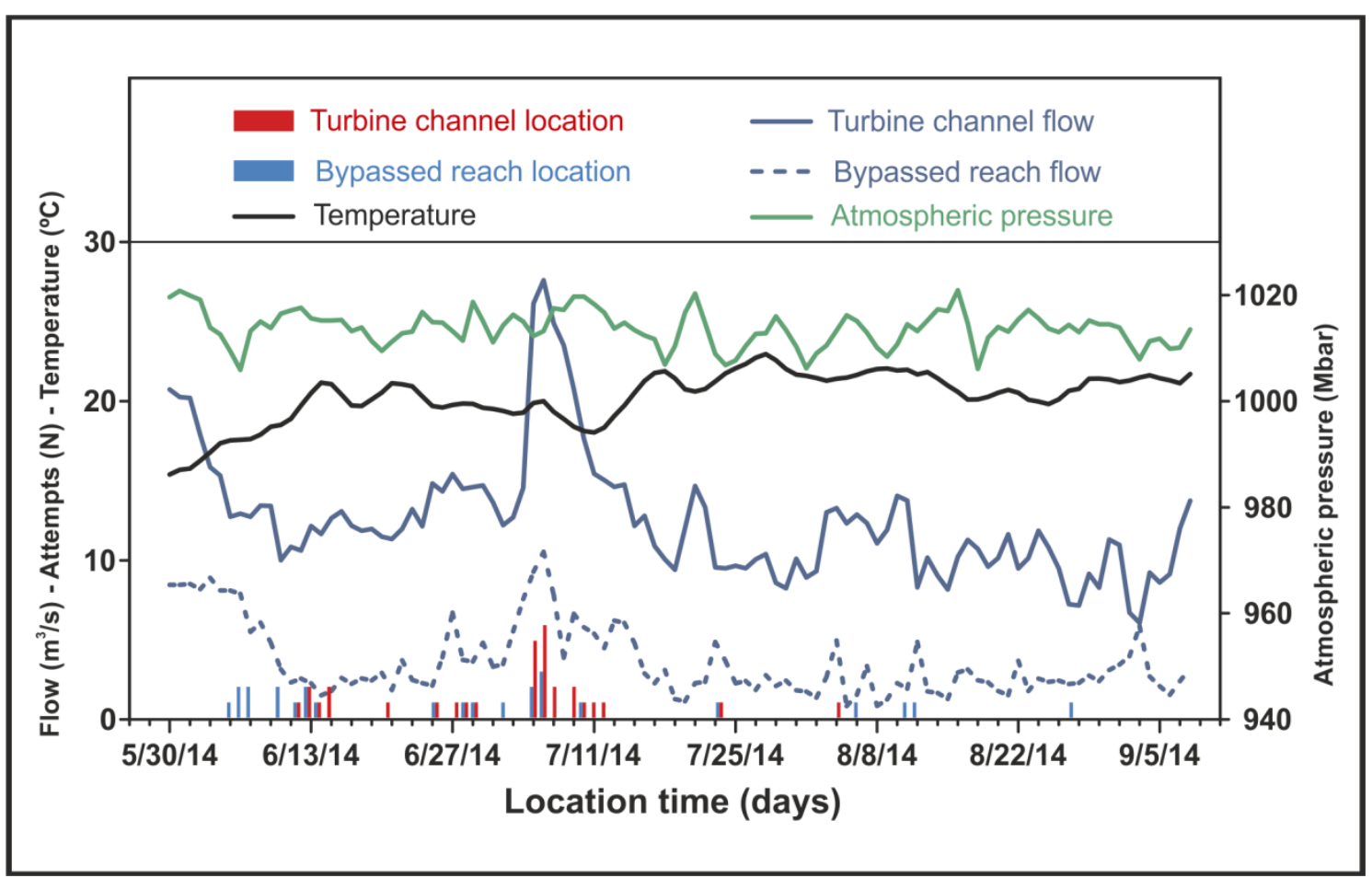

Figure 4. First location of barbel according to the fishway entrance branch (red bar: turbine channel branch; blue bar: bypassed reach branch). Environmental variables are represented as the mean daily value (turbine channel flow: blue line; bypassed reach flow: blue dashed line; water temperature: orange line; atmospheric pressure: black dotted line).

Analysis of possible relationships between attempts per branch and environmental covariates falls outside the scope of conventional statistics due to its particularities: censored data for individuals without an attempt, two possible events of interest, covariates with values that change along the course of the timeline, and different experimental start dates. Therefore, the statistics that best suits this analysis is survival analysis with competing risks and timedependent covariates. Due to the complexity of this calculation, few statistical software 
packages are able to perform this analysis. Recently, some macros have been developed to facilitate this calculation, such as PSHREG for SAS (see Kohl et al., 2015, for further details). Table 4 shows the results with respect to the relationship between locations, approach branch and environmental covariates. To obtain these results, all the covariates were first included in the model. The next step was to select the covariates that best explained the events and provided a better fit for the model. Covariates based on rates, variations and previous days values polluted the model, their rejection increased the power of the chosen variables and they were not significant in any case whatsoever. Hence, $Q, Q$ turbine, $Q_{\text {bypassed, }} T$ and $P$ were chosen. The subsequent step was to remove those with no influence according to each branch (reference P-value $=0.10$; backward selection). The choice of the final model (Table 4 ) was based on influential covariates and the best fit to Akaike's Information Criterion (AIC) and the Schwartz-Bayes criterion (SBC).

Table 4. Statistically significant covariates for each approach branch to the fishway (only the first location was taken into account). Covariates without any influence were eliminated from the model (represented as a: - ). B: regression coefficient; HR: Hazard Ratio; $\mathrm{Cl}=$ Confidence Interval.

\begin{tabular}{|c|c|c|c|c|c|c|}
\hline \multirow{3}{*}{$\begin{array}{l}\text { Statistically } \\
\text { significant } \\
\text { covariates }\end{array}$} & \multicolumn{6}{|c|}{ Approach branch (first location) } \\
\hline & \multicolumn{3}{|c|}{ Turbine channel entrance } & \multicolumn{3}{|c|}{ Bypassed reach entrance } \\
\hline & B & P-value & HR (95\% C.I.) & B & P-value & HR (95\% C.I.) \\
\hline$Q$ & 0.1593 & $<0.0001$ & $1.173(0.115-1.234)$ & - & - & - \\
\hline$Q_{\text {turbine }}$ & - & - & - & - & - & - \\
\hline$Q_{\text {bypassed }}$ & - & - & - & 0.3013 & 0.0032 & $1.352(1.106-1.651)$ \\
\hline $\mathrm{T}$ & -0.3270 & 0.0357 & $0.721(0.532-0.978)$ & -0.9928 & $<0.0001$ & $0.371(0.249-0.551)$ \\
\hline$P$ & - & - & - & -0.1700 & 0.0006 & $0.844(0.776-0.929)$ \\
\hline
\end{tabular}

First, the relationships between flow covariates and the likelihood of location were considered. The positive effect of the total flow discharge $(\mathrm{Q})$ can be seen for the turbine branch, as well as that of the flow discharge through the bypassed reach $\left(Q_{\text {bypassed }}\right)$ for location of the entrance to the bypassed reach. 
Other influential covariates were water temperature and air pressure, both with an inverse effect on the likelihood of location. Temperature had a significant influence on both paths. However, air pressure only influenced the bypassed reach entrance.

\section{Passage analysis}

\section{1) Ascent Success}

The origin of the fish had a significant influence on ascent success (chi-square independence test, $\mathrm{P}<0.001$; logistic regression, $\mathrm{P}=0.020)$, being higher in fish captured upstream $(80.3 \%$ success) than downstream (16.7 \% success).

There were no differences between ascent route success (chi-square independence test, $\mathrm{P}=$ 0.353 ; logistic regression, $P=0.352), 67.7 \%$ success being obtained for the bypassed reach branch and $78.1 \%$ success for the turbine channel branch.

\section{2) Transit time}

Only fish captured upstream were taken into account (only one fish captured downstream successfully ascended the fishway. It was hence impossible to include this category [source = downstream], in the statistical analysis.

There were no differences between routes in any case (median comparison, $\mathrm{P}=0.682$; Logrank test, $\mathrm{P}=0.681$ ) (Table 5).

Table 5. Transit time for fish captured upstream. Total transit time: time since the fish entered the fishway until it reached the antenna furthest upstream. Transit time per meter of height: total transit time divided by height exceeded (Turbine channel branch height exceeded $=4.40 \mathrm{~m}$; Bypassed reach branch height exceeded $=3.90 \mathrm{~m}$ ). IQR: Interquartile Range; SE: Standard Error.

\begin{tabular}{|c|c|c|c|c|}
\hline \multirow{2}{*}{$\begin{array}{l}\text { Ascent fishway } \\
\text { branch }\end{array}$} & \multicolumn{2}{|c|}{ Total transit time (minutes) } & \multicolumn{2}{|c|}{ Transit time per meter height (minutes) } \\
\hline & Median (IQR) & Mean $( \pm S E)$ & Median (IQR) & Mean ( \pm SE) \\
\hline $\begin{array}{l}\text { Turbine channel } \\
\qquad(\mathrm{N}=33)\end{array}$ & $115.1(63.4-205.1)$ & $186.3( \pm 36.7)$ & $26.2(14.4-46.7)$ & $42.4( \pm 8.4)$ \\
\hline $\begin{array}{l}\text { Bypassed reach } \\
\quad(\mathrm{N}=47)\end{array}$ & $116.5(61.4-232.3)$ & $187.5( \pm 29.1)$ & $29.9(15.8-59.7)$ & $48.2( \pm 7.5)$ \\
\hline
\end{tabular}

Moreover, a comparison was carried out between fishway sections (both branches and the main stem, Figures 2 and 5). First, we analyzed the influence of success on transit time. As 
there were no differences in transit time per meter of height $(P=0.316)$ between fish with successful ascents and fish with no success (those which only ascended the fishway partially), both groups were merged and considered jointly. As stated previously, the same occurs with both branches, which were also grouped together. Subsequently, the comparison was made between the main stem and both branches. Due to the statistical differences between standard deviations, the non-parametric test is the best way to make these comparisons. Therefore, a Kaplan-Meier representation was performed (Figure 5), resulting in a shorter transit time through the main stem (median time per meter $=22.3 \mathrm{~min}$ ) than the branches (median time per meter $=36.4 \mathrm{~min})($ Log-rank test, $\mathrm{P}<0.001)$.

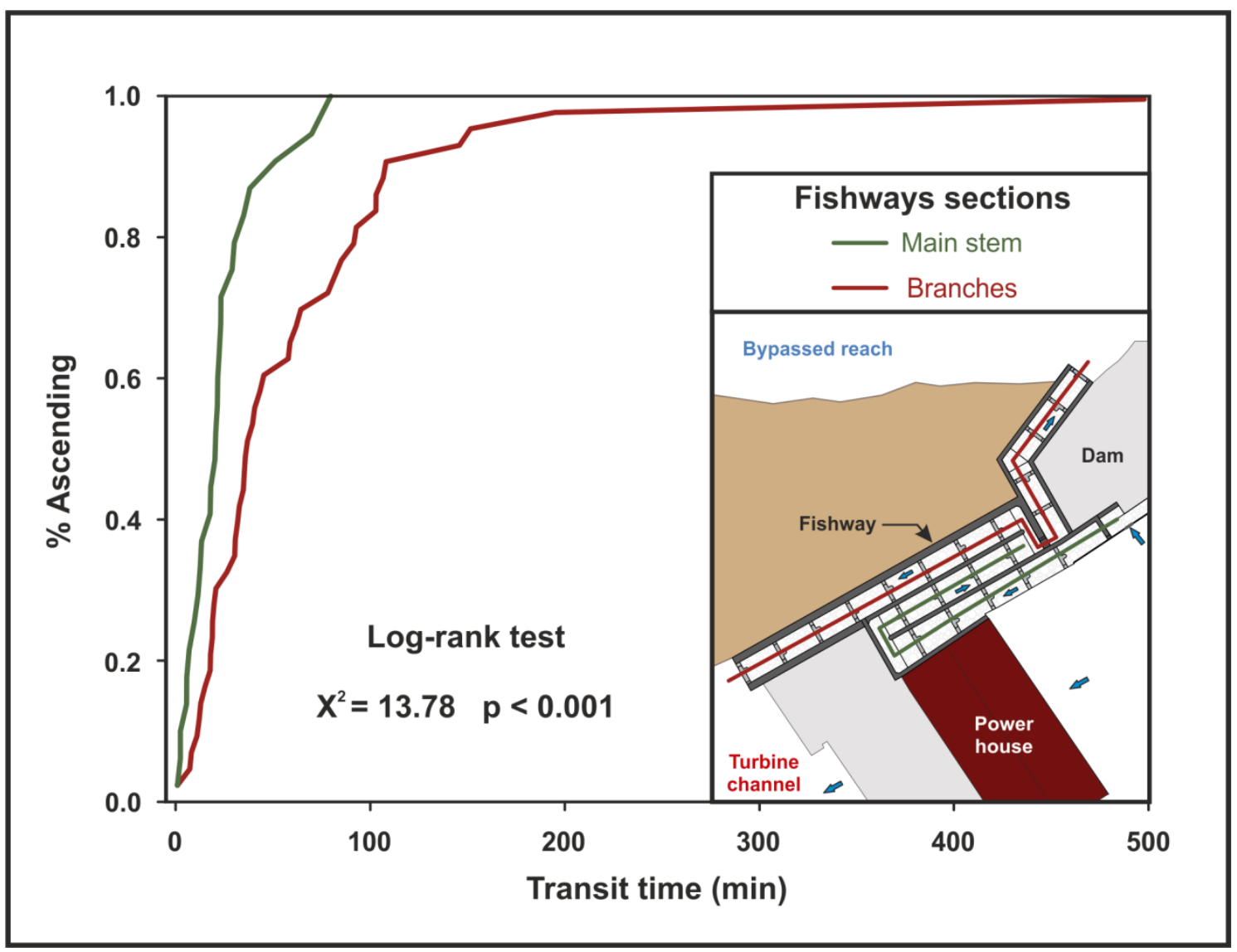

Figure 5. Transit time per meter of height (minutes) and percentage of fish ascending, itemized by fishway sections (the turbine channel branch and bypassed reach branch are dealt with in common due to the lack of statistical differences between their transit times).

\section{Discussion}

This study puts forward a solution, a fishway with two branches, which could be adapted in many dams associated with hydropower plants with a turbine channel and a bypassed reach. It 
would appear to be a good tool to increase the number of fish that locate the fish pass, gathering fish from both routes. This design may reduce the cost of implementing another solution, such as two fish ladders (one per path).

Environmental variables such as flow discharge, water temperature and atmospheric pressure played an important role in fish motivation and movements. Flow discharge seemed to play a key role in entrance location, the likelihood of attempting ascent being greater with higher values of flow discharge. However, significant covariates related to flow were not the same for both paths. Location on the turbine channel was influenced by total flow discharge, not by turbine discharge. The hydraulics of turbine channel hydraulics does not change significantly with flow (i.e., an increase from 9 to $18 \mathrm{~m}^{3} / \mathrm{s}$ results in an increase from 2 to $2.5 \mathrm{~m}$ in mean depth and 0.25 to $0.36 \mathrm{~m} / \mathrm{s}$ in mean velocity). This increase in fish location may thus be related to the onset of motivation downstream from the confluence of both channels; it is easier to find this route due to the higher flow rate under these conditions. For the bypassed reach, fish entrance location was favored by higher values of flow discharge in this route. This is probably due the fact that it is easier to find this route under these conditions (i.e., an increase from 2 to $4 \mathrm{~m}^{3} / \mathrm{s}$ results in an increase in the vicinity to the fishway river branch from 0.3 to $0.46 \mathrm{~m}$ in mean depth and 0.38 to $0.63 \mathrm{~m} / \mathrm{s}$ in mean velocity). Nonetheless, most activity centered around flow peak events related to rain or river regulation. These local peaks alter hydraulic conditions and stimulate fish movement (Cardoso, 2014).

There were no statistical differences in path selection during the experiments, however. Although flow discharge in the bypassed reach was lower (the proportion between bypassed reach discharge and turbine discharge was $21.1+/-1.3 \%$ ), it was higher than minimum attraction flow recommendations (1-10 \%) (Larinier et al., 2002; NMFS 2008). In all probability, both local distributions of fish downstream from the confluence (right or left bank) and hydraulic variables related to flow determine fish path selection (Lucas et al., 2001). The time taken since release to locate one of the entrances seemed to be slightly different. Throughout most of the experiment, fish located the bypassed reach entrance faster. This entrance concentrates $50 \%$ of the discharge downstream of the dam, while the turbine channel entrance is obscured by the turbine exit.

Water temperature during the experiments was inversely related to fish activity. This variable varied between 15 and $23^{\circ} \mathrm{C}$. For the same species in a tributary of the Duero River, temperatures higher than $15{ }^{\circ} \mathrm{C}$ in May activated fish movement, while values higher than $22^{\circ} \mathrm{C}$ 
in late June reduced barbel activity (Bravo-Córdoba et al., 2014). Other studies on Iberian barbel showed an evident relationship between discharge, temperature and motivation (Cardoso, 2014; Sanz-Ronda et al., 2015, 2016); all with a positive effect (higher temperatures improved the likelihood of attempting ascent). Water temperature decreased during flow peaks. Hence, this variable effect is also related to flow variation and, in all probability, both parameters jointly stimulate fish movement.

Atmospheric pressure was a significant variable influencing fish movement in the bypassed reach. Lower values of this parameter increased location in this reach, probably due to the fact that fish staying in shallower areas feel changes in this variable more than others remaining in deeper areas. Few papers relate atmospheric pressure to the movements of rheophilic cyprinids. Prchalova et al. (2006) analyzed this variable, among other environmental variables, reporting a higher number of movements for cyprinids with extreme pressure values. The opposite relationship between fish activity (likelihood of location) and air pressure could be related to periods of atmospheric instability, which are in turn related to lower air pressure that leads to episodes of rainfall and hence increased flow rates.

Significant differences were found in terms of fish origin, both in location and in passage. Motivation could be one of the main factors influencing this relationship. Fish captured upstream were trapped in a fishway and released into a different habitat to their own and, hence, with a clear migratory pattern and far from their native habitat. Fish captured upstream probably felt the need to recovery their territory, a premise that has already been studied for Iberian barbel by other authors (Alexandre et al., 2015).

On the other hand, a large proportion of fish captured downstream might not have felt the need to migrate to new or spawning territories. The existence of a differentiated population between the resident and migratory fraction of fish has already been established for cyprinids (Brodersen, 2008; Chapman 2012 a, b). The resident fraction shows annual fidelity to spawning areas; just the opposite to the migratory fraction (Ovidio et al., 2007). Downstream barbels had not been able to pass the dam for more than 70 years; so it is assumed that the resident fraction predominates.

The existence of suitable spawning sites just downstream from the dam strengthens this assumption (Leeuw and Winter, 2008). Spawning grounds were detected in this area. 
Further interesting results regarding fishway passage were related to the differences between the two branches and the main stem. Transit time was significantly lower in the latter. The main differences between them comprise the width of the bottom orifices and notches and the differences in turbulence, particularly the Volumetric Energy Dissipation (VED). The size of the bottom orifices and notches could play a key role for this species. Other studies on Iberian barbel have revealed differences in the pattern of use within these areas (Silva et al., 2009; Branco et al., 2013; Bravo-Córdoba et al., 2014), though none finds significant relationships between orifice size and passage. Turbulence is one of the main factors influencing fish pass efficiency (Castro-Santos et al., 2009), although the best turbulence measure related to fish swimming performance has yet to be determined (Kemp, 2012; Lacey et al., 2012). VED is probably the easiest and one of the most widespread parameters used by fishway designers to indicate how good the structure for fish ascent is (Kynard et al., 2011). Most of the scientific literature cites the inverse relationship between VED and passage efficacy (Santos et al., 2012; Fouche et al., 2013). In this case, however, a higher (though not excessively higher) value was related to faster ascent. Moreover, the VED in the two branches was very low and the sidewalls of the fishway were very high, creating a tunnel effect. Both factors could possibly affect fish motivation, thereby increasing ascent time via these branches. In trials employing Iberian barbel and electromyograms, Alexandre et al. (2013) found a positive relationship between turbulent kinetic energy, turbulence intensity and the horizontal vector of Reynold shear stress with swimming speed.

As regards data analysis, few robust statistical analyses consider environmental variables (which change over time), the choice of different migration routes (and the competing relationship between them) or include the fish that do not make ascent attempts. Data of this kind, with temporal allocation of events and without a normal distribution, find a good statistical study tool in survival analysis (Castro-Santos, 2012) with procedures such as those performed in the present study.

Finally, important questions remain and further research is needed for barbel and other species, flow regimes and fishway designs in order to improve fish passage and achieve more cost-effective engineering. Further, in-depth study of powerful statistical tools when looking for relationships between environmental variables and fish movement behavior is likewise needed. 


\section{Acknowledgments}

Francisco Javier Bravo Córdoba carried out this research with the support of a Ph.D. grant from the University of Valladolid PIF-UVa 2011, Spain. Leandro Fernandes Celestino received funding for research via a "bolsa de produtividade em desenvolvimento tecnológico e extensão inovadora vigente CNPq - Conselho Nacional de Desenvolvimento Científico e Tecnológico, Brasil”.

We specifically wish to thank IBERDROLA RENOVABLES for letting us use the company's installations and the GEA-Ecohidráulica research group for their help in fieldwork.

\section{References}

Alexandre C., Quintella B. R., Silva A., Mateus C., Romão F., Branco P., Ferreira M. T. and Almeida P. R., 2013. Use of electromyogram telemetry to assess the behavior of the Iberian barbel (Luciobarbus bocagei Steindachner, 1864) in a pool-type fishway. Ecological Engineering. 51, 191-202.

Alexandre C., Almeida P., Neves T., Mateus C., Costa J. and Quintella B. 2015. Effects of flow regulation on the movement patterns and habitat use of a potamodromous cyprinid species. Ecohydrology.

Allison P. D. 2010. Survival analysis using SAS: a practical guide,Sas Institute.

Baras E., Lambert H. and Philippart J. 1994. A comprehensive assessment of the failure of Barbus barbus spawning migrations through a fish pass in the canalized River Meuse (Belgium). Aquatic Living Resources. 7, 181-189.

Benitez J., Matondo B. N., Dierckx A. and Ovidio M. 2015. An overview of potamodromous fish upstream movements in medium-sized rivers, by means of fish passes monitoring. Aquatic Ecology. 1-17.

Bizzotto P., Godinho A. L., Vono V., Kynard B. and Godinho H. P. 2009. Influence of seasonal, diel, lunar, and other environmental factors on upstream fish passage in the Igarapava Fish Ladder, Brazil. Ecology of Freshwater Fish. 18, 461-472. 
Bjornn T. C., Hunt J., Tolotti K., Keniry P. and Ringe R., 1992. Migration of adult Chinook salmon and Steelhead past dams and through reservoirs in the Lower Snake river and into tributaries1992. Annual Technical report. U.S. Army Corps of Engineers, Portland, OR.

Branco P., Santos J. M., Katopodis C., Pinheiro A. and Ferreira M. T. 2013. Effect of flow regime hydraulics on passage performance of Iberian chub (Squalius pyrenaicus)(Günther, 1868) in an experimental pool-and-weir fishway. Hydrobiologia. 714, 145-154.

Branco P., Segurado P., Santos J. M. and Ferreira M. T. 2014. Prioritizing barrier removal to improve functional connectivity of rivers. Journal of Applied Ecology. 51, 1197-1206.

Bravo-Córdoba F. J., Sanz-Ronda F. J., Ruiz-Legazpi J., Fuentes-Pérez J. F. and Salgado V. 2014. Ecohydraulics monitoring and improvement of fish passes in the Duero Basin: the case of river Tormes in Santibáñez de Béjar (Salamanca). . V Jornadas Ibéricas de Ictiología . Lisboa, Portugal.

Bravo-Córdoba F. J., Sanz-Ronda F. J., Fuentes-Pérez J. F., Ruiz-Legazpi J., Salgado V., GarcíaVega A., Valbuena-Castro J. and Peña-Garrido A. 2015. Fishway with two entrance locations. Fish Passage 2015 . Groningen, Netherlands.

Britton J. and Pegg J. 2011. Ecology of European barbel Barbus barbus: implications for river, fishery, and conservation management. Review of Fisheries Sciences. 19, 321-330.

Brodersen J., Nilsson P. A., Hansson L., Skov C. and Brönmark C. 2008. Condition-dependent individual decision-making determines cyprinid partial migration. Ecology, 89, 1195-1200.

Brown R. S., Geist D. R. and Mesa M. G. 2002. The use of electromyogram (EMG) telemetry to assess swimming activity and energy use of adult spring Chinook salmon migrating through the tailraces, fishways, and forebays of Bonneville Dam, 2000 and 2001. US Army Corps of Engineers, Portland, OR.

Bunt C. M., Katopodis C. and McKinley R. 1999. Attraction and passage efficiency of white suckers and smallmouth bass by two Denil fishways. North American Journal of Fisheries Management. 19, 793-803.

Cardoso G. R. 2014. Monitorização da passagem para peixes do açude-ponte em Coimbra: otimização da metodologia de contagem. Thesis-dissertation, Universidade de Évora.

Castro-Santos T. and Haro A. 2010. Fish guidance and passage at barriers. In: Domenici P. B.and Kapoor B. G.(eds.),Fish Locomotion An Eco-ethological Perspective, Science Publishers, 48-62. 
Castro-Santos T., Haro A. and Walk S. 1996. A passive integrated transponder (PIT) tag system for monitoring fishways. Fisheries Research. 28, 253-261.

Castro-Santos T. and Haro A., 2003. Quantifying migratory delay: a new application of survival analysis methods. Canadian Journal of Fisheries and Aquatic Sciences. 60, 986-996.

Castro-Santos T., Cotel A. and Webb P. 2009. Fishway evaluations for better bioengineering: an integrative approach. Challenges for Diadromous Fishes in a Dynamic GlobalEnvironment, 557.

Castro-Santos T.and Perry R. W. 2012. Time-to-event analysis as a framework for quantifying fish passage performance. In: Telemetry techniques: a user guide for fisheries research.American Fisheries Society, Bethesda, Maryland, 427-452.

Castro-Santos T. and Vono V. 2013. Posthandling Survival and PIT Tag Retention by Alewives-A Comparison of Gastric and Surgical Implants. North American Journal of Fisheries Management. 33, 790-794.

Castro-Santos T. 2012. Adaptive fishway design: a framework and rationale for effective evaluations. 76.

Chapman B., Hulthén K., Brodersen J., Nilsson P. A., Skov C., Hansson L. and Brönmark C. 2012. Partial migration in fishes: causes and consequences. Journal of Fish Biology. 81, 456-478.

Chapman B., Skov C., HulthÈn K., Brodersen J., Nilsson P. A., Hansson L. and Brönmark C. 2012. Partial migration in fishes: definitions, methodologies and taxonomic distribution. Journal of Fish Biology. 81, 479-499.

Clabough T., Johnson E., Keefer M., Caudill C. and Moser M., 2011. General passage and fishway use summaries for adult pacific lamprey at Bonneville, The Dalles and John Day dams, 2010. Technical report 2011-5. Idaho cooperative fish and wildlife research unit.

Collares-Pereira M., Martins M., Pires A., Geraldes A. and Coelho M. 1996. Feeding behaviour of Barbus bocagei assessed under a spatio-temporal approach. Folia Zoologica. 45 (1), 65-76.

Cooke S. J. and Hinch S. G. 2013. Improving the reliability of fishway attraction and passage efficiency estimates to inform fishway engineering, science, and practice. Ecological Engineering. 58, 123-132.

Doadrio I. 2001. Atlas y libro rojo de la ictiofauna continental española. NIMAM-CSCI, Madrid. 
Doadrio I., Perea S., Garzón-Heydt P. and González J. 2011. Ictiofauna continental española. Bases para su seguimiento. Ministerio de Medio Ambiente y Medio Rural y Marino, Centro de Publicaciones.

FAO/DVWK. 2002. Fish passes-Desing, dimensions and monitoring. Roma, Fao,119.

Ficke A. D., Myrick C. A. and Kondratieff M. C. 2012. The effects of PIT tagging on the swimming performance and survival of three nonsalmonid freshwater fishes. Ecological Engineering. 48, 86-91.

Fouché $P$. and Heath R. 2013. Functionality evaluation of the xikundu fishway, Luvuvhu river, South Africa. African Journal of Aquatic Science. 38, 69-84.

Franklin A. E., Haro A., Castro-Santos T. and Noreika J. 2012. Evaluation of nature-like and technical fishways for the passage of alewives at two coastal streams in New England. Transactions of American Fisheries Society. 141, 624-637.

Hosmer D., Lemeshow S. and May S. 2008. Applied survival analysis: Regression modeling of time to event data. Wiley-Interscience.

Illies J. and Botosaneanu L. 1963. Problèmes et méthodes de la classification et de la zonation écologique des eaux courantes, considerées surtout du point de vue faunistique. Limnology. $12,1-57$.

Johnson E. L., Caudill C. C., Clabough T. S., Keefer M. L., Jepson M. A. and Moser M. L. 2010. Effects of lowered fishway water velocity on fishway entrance success by adult Pacific Lamprey at Bonneville dam, 2007-2009. US Army Corps of Engineers, Portland, Portland, OR.

Johnson J., Patterson D., Martins E., Cooke S. and Hinch S., 2012. Quantitative methods for analysing cumulative effects on fish migration success: a review. Journal of Fish Biology. 81, $600-631$.

Keefer M. L., Caudill C. C., Clabough T. S., Jepson M. A., Johnson E. L., Peery C. A., Higgs M. D., Moser M. L. and Tonn W. 2013. Fishway passage bottleneck identification and prioritization: a case study of Pacific lamprey at Bonneville Dam. Canadian Journal of Fisheries and Aquatic Sciences. 70, 1551-1565.

Keefer M. L., Caudill C. C. and Moser M. L. 2014. Fishway Bottleneck Relief Models: a Case Study using Radio-Tagged Pacific Lampreys. Transactions of American Fisheries Society. 143, 1049-1060. 
Keefer M. L. and Caudill C. C. 2015. Estimating thermal exposure of adult summer steelhead and fall Chinook salmon migrating in a warm impounded river. Ecology of freshwater fish.

Keefer M., Joosten D., Williams C., Nauman C., Jepson M., Peery C., Bjornn T., Ringe R., Tolotti K. and Lee S. 1997. Adult salmon and steelhead passage through fishways and transition pools at Bonneville dam, 1997-2002. US Army Corps of Engineers, Portland, Portland, OR.

Keefer M., Peery C., Bjornn T., Jepson M., Tolotti K., Ringe R. and Stuehrenberg L. 2007. Adult salmon and steelhead passage through fishways and transition pools at the Dalles dam, 19972001. Technical report. US Army Corps of Engineers, Portland, Portland, OR.

Kemp P. S. 2012. Bridging the gap between fish behaviour, performance and hydrodynamics: an ecohydraulics approach to fish passage research. River Research and Applications. 28, 403406.

Kleinbaum D. G.and Klein M. 2012. Survival analysis. A self-learning text book, Springer, 495.

Kohl M., Plischke M., Leffondré K. and Heinze G. 2015. PSHREG: A SAS macro for proportional and nonproportional subdistribution hazards regression. Computer Methods and Programs in Biomedicins. 118, 218-233.

Kynard B., Pugh D. and Parker T. 2011. Passage and behaviour of cultured Lake Sturgeon in a prototype side-baffle fish ladder: I. Ladder hydraulics and fish ascent. Journal of Applied Ichthyology. 27, 77-88.

Lacey R., Neary V. S., Liao J. C., Enders E. C. and Tritico H. M. 2012. The IPOS framework: linking fish swimming performance in altered flows from laboratory experiments to rivers. River Research and Applications. 28(4), 429-443.

Larinier M. 1992. Location of fishways at barriers. Bulletin Francais de la Peche et de la Pisciculture (France).

Larinier M. 2002. Biological factors to be taken into account in the design of fishways, the concept of obstructions to upstream migration. Bulletin Francais de la Peche et de la Pisciculture. 28-38.

Lin G., So Y. and Johnston G. 2012. Analyzing survival data with competing risks using SAS ${ }^{\circledR}$ software. 2102. 
Lobón-Cerviá J. and Fernández-Delgado C. 1984. On the biology of the barbel (Barbus barbus bocagei) in the Jarama river. Folia Zoologica. 33, 371-384.

Lucas M. C. and Batley E. 1996. Seasonal movements and behaviour of adult barbel Barbus barbus, a riverine cyprinid fish: implications for river management. Journal of Applied Ecology. 1345-1358.

Lucas M. C., Baras E., Thom T. J., Duncan A. and Slavík O. 2001. Migration of freshwater fishes, Wiley Online Library.

Makrakis S., Castro-Santos T., Makrakis M. C., Wagner R. L. and Adames M. S. 2012. Culverts in paved roads as suitable passages for Neotropical fish species. Neotropical Ichthyology. 10, 763770.

Mallen-Cooper M. and Brand D. A. 2007. Non-salmonids in a salmonid fishway: what do 50 years of data tell us about past and future fish passage? Fisheries Management and Ecology. $14,319-332$.

Mantel N. 1966. Evaluation of survival data and two new rank order statistics arising in its consideration. Cancer Chemotherapy Reports. 50, 163-170.

Naughton G. P., Caudill C. C., Peery C. A., Clabough T. S., Jepson M. A., Bjornn T. C. and Stuehrenberg L. C. 2007. Experimental evaluation of fishway modifications on the passage behaviour of adult Chinook salmon and steelhead at Lower Granite Dam, Snake River, USA. 23, 99-111.

NMFS (National Marine Fisheries Service) 2008. Anadromous Salmonid Passage Facility Design,NMFS, Northwest Region, Portland, Oregon.

Noonan M. J., Grant J. W. and Jackson C. D. 2012. A quantitative assessment of fish passage efficiency. Fish and Fisheries. 13, 450-464.

Ostrand K. G., Zydlewski G. B., Gale W. L. and Zydlewski J. D. 2011. Long term retention, survival, growth, and physiological indicators of juvenile salmonids marked with passive integrated transponder tags. American Fisheries Society Symposium, 76.

Ovidio M., Parkinson D., Philippart J. and Baras E. 2007. Multiyear homing and fidelity to residence areas by individual barbel (Barbus barbus). Belgian Journal of Zoology. 137, 183-190. 
Pavlov D., Sadkovskii R., Kostin V. and Lupandin A. 2000. Experimental study of young fish distribution and behaviour under combined influence of baro-, photo-and thermo-gradients. Journal of Fish Biology. 57, 69-81.

Powell T. M. and Bagnell M. E. 2012. Your "survival" guide to using time-dependent covariates. In Sas Global Forum, 168.

Prchalova M., Horky P., Slavik O., Vetesnik L. and Halacka K. 2011. Fish occurrence in the fishpass on the lowland section of the River Elbe, Czech Republic, with respect to water temperature, water flow and fish size. Folia Zoologica. 60.

Prchalová M., Slavík O. and Bartoš L., 2006. Patterns of cyprinid migration through a fishway in relation to light, water temperature and fish circling behaviour. International Journal of River Basin Management. 4(3), 213-218.

Rakowitz G., Berger B., Kubecka J. and Keckeis H., 2008. Functional role of environmental stimuli for the spawning migration in Danube nase Chondrostoma nasus (L.). Ecology of Freshwater Fish. 17, 502-514.

Reischel T. S. and Bjornn T. C. 2003. Influence of fishway placement on fallback of adult salmon at the Bonneville Dam on the Columbia River. North American Journal of Fisheries Management. 23, 1215-1224.

Rodriguez-Ruiz A. and Granado-Lorencio C. 1992. Spawning period and migration of three species of cyprinids in a stream with Mediterranean regimen (SW Spain). Journal of Fish Biology. 41, 545-556.

Rosgen D. L. and Silvey H. L., 1996. Applied river morphology, Wildland Hydrology Pagosa Springs, Colorado.

Santos J., Ferreira M., Godinho F. and Bochechas J. 2002. Performance of fish lift recently built at the Touvedo Dam on the Lima River, Portugal. Journal of Applied Ichthyology. 18, 118-123.

Santos J., Ferreira M., Godinho F. and Bochechas J. 2005. Efficacy of a nature-like bypass channel in a Portuguese lowland river. Journal of Applied Ichthyology. 21, 381-388.

Santos J. M., Branco P., Katopodis C., Ferreira T. and Pinheiro A., 2014. Retrofitting pool-andweir fishways to improve passage performance of benthic fishes: Effect of boulder density and fishway discharge. Ecological Engineering. 73, 335-344. 
Santos J. M., Pinheiro P. J., Ferreira M. T. and Bochechas J. 2008. Monitoring fish passes using infrared beaming: a case study in an Iberian river. Journal of Applied Ichthyology. 24, 26-30.

Sanz Ronda F. J., Bravo Córdoba F. J. and Martínez de Azagra Paredes A. 2010. Estaciones de aforo V-flat y peces migradores de la Península Ibérica: problemas y soluciones. Ingeniería civil, $158,111-119$.

Sanz Ronda F., Bravo F., Fuentes J., Ruiz Legazpi J., García Vega A., Ramos N., Salgado V. and Martínez de Azagra A. 2013. Pasos para peces: escalas y otros dispositivos de paso. Notas técnicas del CIREF, no 7.

Sanz-Ronda F. J., Ruiz-Legazpi J., Bravo-Córdoba F. J., Makrakis S. and Castro-Santos T. 2015. Sprinting performance of two Iberian fish: Luciobarbus bocagei and Pseudochondrostoma duriense in an open channel flume. Ecological Engineering. 83, 61-70.

Sanz-Ronda F. J., Bravo-Córdoba F. J., Fuentes-Pérez J. F. and Castro-Santos T. 2016. Fish behavior in a vertical slot fishway: comparing ascent ability of brown trout, Salmo trutta, and two iberian cyprinids: Iberian barbel, Luciobarbus bocagei, and northern straight-mouth nase, Pseudochondrostoma duriense. Knowledge and Management of Aquatic Ecosystems. 417, 10.

Silva A. T., Santos J. M., Franco A. C., Ferreira M. T. and Pinheiro A. N. 2009. Selection of Iberian barbel Barbus bocagei (Steindachner, 1864) for orifices and notches upon different hydraulic configurations in an experimental pool-type fishway. Journal of Applied Ichthyology. 25, 173177.

Silva A. T., Santos J. M., Ferreira M. T., Pinheiro A. N. and Katopodis C. 2011. Effects of water velocity and turbulence on the behaviour of Iberian barbel (Luciobarbus bocagei, Steindachner 1864) in an experimental pool-type fishway. River Research and Applications. 27, 360-373.

Silva A. T., Katopodis C., Santos J. M., Ferreira M. T. and Pinheiro A. N. 2012. Cyprinid swimming behaviour in response to turbulent flow. Ecological Engineering. 44, 314-328.

Slavík O., Horký P. and Bartoš L. 2009. Occurrence of cyprinids in fish ladders in relation to flow. Biologia. 64, 999-1004.

Stansell R. J.andBeck L. M. 2002. Evaluation of fish behavior passing weirs where adult PIT-tag detectors are installed at Bonneville Dam, 2001,US Army Corps of Engineers. 
Thiem J. D., Broadhurst B. T., Lintermans M., Ebner B. C., Clear R. C. and Wright D. 2013. Seasonal differences in the diel movements of Macquarie perch (Macquaria australasica) in an upland reservoir. Ecology of Freshwater Fish. 22, 145-156.

Turner A. R., Kuskie J. R. and Kostow A. E. 1983. Evaluation of adult fish passage at Little Goose and Lower Granite dams, 1981. Technical report. U.S. Army Corps of Engineers, Portland District. 


\section{CONCLUSIONES RELEVANTES}

A continuación se exponen las principales conclusiones extraídas del conjunto de experimentos Ilevados a cabo en la presente tesis (ver Resultados I, II y III para más detalle).

Los ciprínidos reófilos como el barbo común y la boga del Duero ascienden las escalas de artesas a una velocidad similar a la trucha común.

Los caudales de funcionamiento habitual y los diseños más comunes de las escalas, en la práctica se pueden considerar adecuados, ya que no generan tiempos de ascenso elevados.

Estos tiempos de ascenso no deberían suponer un problema en lo relativo a retrasos en la migración.

Es necesario tener en cuenta que el tiempo de ascenso se ve incrementado por la presencia de los estanques de descanso en curva.

Bajo condiciones similares de potencia disipada, el barbo asciende más rápido los vertederos sumergidos con orificio de fondo que las hendiduras verticales. En cualquier caso los tiempos de ascenso se consideran reducidos en ambos casos.

El origen de los peces (aguas arriba o abajo del obstáculo) parece tener influencia clara en la motivación para moverse.

D En experimentos donde los peces son estabulados, debe tenerse en cuenta y mencionarse siempre dicho factor. Las conclusiones obtenidas reflejan una aptitud natatoria igual o menor que en condiciones naturales.

En experimentos con peces marcados y puestos en libertad, es conveniente prever una utilización de las escalas bastante menor al del total de la muestra.

Las variables ambientales juegan un papel muy importante en los movimientos migratorios, pero con efectos diferentes en función del resultado analizado (localización, motivación, ascenso).

En centrales hidroeléctricas fluyentes, para analizar la localización, no solo es interesante el caudal total que circula por el río, sino que también es importante la valoración de forma independiente del caudal turbinado y del ecológico.

La longitud de los peces tiene un efecto significativo en el tiempo de ascenso, disminuyendo el mismo para tamaños mayores.

Sería conveniente revisar los valores de potencia disipada recomendados habitualmente para estas especies, no solo en su valor máximo sino también en el rango óptimo de funcionamiento. 


\section{OTRAS CONSIDERACIONES Y RECOMENDACIONES}

Se ha considerado de interés exponer no solo las conclusiones relativas a los resultados obtenidos, sino también a la metodología y las posibles líneas de trabajo futuro para que sean de utilidad, tanto en la revisión de este estudio como en otros similares que puedan llevarse a cabo. Por último, también se han añadido una serie de recomendaciones técnicas derivadas de la experiencia en campo en estos años, las cuales se consideran importantes para la mejora de la ingeniería en este tipo de obras.

\section{Relativas a la metodología utilizada}

Para facilitar su comprensión se ha seguido una estructura similar a la expuesta en el apartado de metodología, presentando para cada subapartado las experiencias obtenidas al respecto:

- Zona de estudio:

Cuanto menores sean los desplazamientos y mejores los accesos, el trabajo se facilita en gran medida. Son frecuentes las visitas necesarias para todas las operaciones de montaje, calibrado, seguimiento y mantenimiento, influyendo mucho en los costes en función de estas distancias y/o tiempos. Además, es necesario mover equipos pesados, por lo que accesos hasta el pie de la escala fáciles y seguros mejoran las condiciones de trabajo.

$>$ Los lugares con gran afluencia de gente pueden generar problemas en la seguridad de los equipos e interferencias en el comportamiento de los peces.

> Los datos climáticos, foronómicos y de calidad de aguas de estaciones cercanas y disponibles facilitan la interpretación de los resultados.

- Escalas de peces:

$>$ Ubicación en el río: situadas en una de las márgenes del río facilita todas las operaciones de instalación. En algún caso puede ser un problema al ser más accesible y por tanto manipulable por personal ajeno.

Seguridad de los movimientos por encima y dentro de la escala: son muchos los desplazamientos que hay que realizar, tanto por encima como por dentro del paso. Por ello es necesario que los muros tengan una anchura mínima que permita transitar con seguridad (aprox. $25 \mathrm{~cm}$ ) y en caso contrario instalar plataformas auxiliares. Si la altura de caída libre desde los muros sea superior a 2 metros, se hace necesaria la instalación de líneas de seguridad o análogos sistemas de protección. También es importante tener en 
cuenta que en zonas con heladas frecuentes, el tránsito por las escalas entraña un peligro mayor debido a la presencia habitual de hielo.

Presencia de compuerta en la entrada de agua: es muy importante tanto para el control del caudal que circula por la escala, como para las labores de instalación de los equipos y mantenimiento de la propia obra (limpieza y reparaciones).

Presencia de entramados metálicos tipo "tramex": en algunos casos, para evitar caídas o furtivismo, las escalas están recubiertas con mallas metálicas rígidas tipo tramex. Generalmente dificultan bastante la labor de instalación de equipos, calibración y mantenimiento, ya que moverse por dentro de la escala es bastante más complicado y mover dichas mallas puede ser laborioso y peligroso. Sin embargo, sí que mejora la seguridad de los equipos ante robos una vez instalados.

Toma de corriente eléctrica: si en las cercanías de la escala se cuenta con una toma de corriente se ven facilitadas la mayoría de tareas. Es posible trabajar con equipos de energía solar pero son mucho menos estables y con alto riesgo de sufrir vandalismo.

Relación con la propiedad de la escala: es muy importante contar con una buena relación y facilidad de comunicación con quien ostenta la propiedad de la escala, ya que es necesario acceder con frecuencia a sus instalaciones, utilizar sus tomas de corriente, su vigilancia, control de caudales, etc.

El mantenimiento y limpieza de las escalas de peces debe ser un punto fundamental durante la vida útil de las mismas, con una base legal y un seguimiento suficiente que lo asegure. Son multitud los pasos visitados y en un porcentaje importante presentaban problemas, algunos serios, debidos principalmente a obturaciones, roturas, descalces y depósitos de arrastres.

Para la caracterización topográfica una estación total nos proporciona datos suficientes y precisos, así como una relación adecuada con el tiempo invertido en tomar dichas medidas. A su vez, un flexómetro también es fundamental por lo económico, útil y rápido que resulta.

Para la caracterización hidráulica:

- Un molinete hidráulico nos proporciona datos fiables de velocidad del agua en los vertederos, donde la velocidad predominante es en un eje y positiva. En otros puntos de la escala no proporciona medidas precisas o suficientes.

- Para obtener el caudal circulante por la escala el sistema más preciso es el aforo químico. Para ello es necesario utilizar trazadores no contaminantes (por ej. Rodamina 
WT) y, en el caso de experimentar con peces, realizarlo previa o posteriormente a su presencia en la escala, evitando así posibles interferencias.

$>$ Una caracterización tanto topográfica como hidráulica en detalle es muy útil a la hora de trabajar en gabinete. Esa inversión previa en tiempo suele ser rentable a posteriori, ya que evita imprecisiones y/o visitas futuras a campo.

- Muestra de peces:

$>$ La presencia de tramos de río vadeables y con presencia de peces conocida mejora los rendimientos a la hora de obtener las muestras. En esta labor es de gran utilidad la información de la guardería fluvial y los servicios de medio ambiente, así como de empresas que hayan realizado muestreos en la zona y pescadores.

$>$ Son muchas las variables que influyen en el muestreo de peces y por tanto tendremos que tener en cuenta que el escenario teórico ideal de tamaño de muestra en muchas ocasiones tendrá que ser modificado. Es necesario tener flexibilidad y adaptabilidad al respecto para poder llevar a cabo los experimentos.

La combinación de estrategias y sistemas de captura ayudan a mejorar la muestra. La pesca eléctrica, junto con el trampeo en escalas cercanas y el uso de redes de captura activa tipo "atarraya" nos ha proporcionado los mejores resultados de muestreo. Es interesante analizar la influencia sobre el comportamiento del pez una vez soltado en función del sistema de captura, ya que se vienen detectando ciertas tendencias, pero sin confirmación estadística.

$>$ Las truchas, y especialmente las bogas, se han mostrado muy sensibles al manejo. Los indicios visuales de elevado nivel de estrés son importantes y por tanto hay que cuidar especialmente todo el proceso con estas especies. La reducción de los tiempos de estabulación, aguas de calidad, reposo y recuperación en viveros sobre el propio río en zonas con renovación de agua y evitar el tránsito continuado en las cercanías parece mejorar la situación (a falta de experimentación y análisis específico).

$>$ Los diferentes muestreos llevados a cabo durante estos años en varios puntos de la cuenca del Duero, así como las indagaciones al respecto, nos llevan a pensar que la situación de las poblaciones de boga del Duero requiere de una atención especial. En los últimos años se ha venido constatando por los servicios de medio ambiente, empresas dedicadas al muestreo de peces y por pescadores el descenso importante de sus poblaciones. Esto ha provocado que en muy pocos casos hayamos obtenido muestras lo suficientemente grandes como para realizar una experimentación representativa. 
- Marcaje y seguimiento:

Es necesario conocer de manera contrastada la influencia del proceso de marcaje (estabulación, anestesia, tipo de marca), principalmente para las especies de ciprínidos ibéricos, para las cuales no hay estudios hasta la fecha. Especialmente preocupa la influencia en momentos de migración, donde parece que son mucho más sensibles y puede verse afectado en mayor medida el instinto reproductor.

Siempre que sea posible es recomendable realizar los estudios durante más de una campaña, especialmente para experimentos con peces libres en el río. Esta recomendación es debida al número de peces que no realizan ningún intento en la misma campaña en la que han sido marcados, pero que por la experiencia de otros estudios realizados durante varios años, aumenta su participación.

El periodo migratorio para las especies estudiadas solo se produce una vez por año y el momento álgido en unos pocos días. Por lo tanto es necesario conocer bien las fechas teóricas para cada lugar y además hacer un seguimiento previo para poder trabajar con peces en condiciones óptimas de estimulación.

Cuanto menor es el tamaño de la marca PIT peor es el rango de lectura de las antenas. EI funcionamiento óptimo para los estudios realizados se ha conseguido con marcas de 23 $\mathrm{mm}$ de longitud, permitiendo su uso en individuos de tallas superiores (longitud furcal) a $12 \mathrm{~cm}$.

Los equipos de recepción de la señal de los PIT-tag tienen problemas comprobados en las siguientes circunstancias:

- Si están conectados con ordenadores portátiles, lo cual se soluciona con ordenadores de mesa.

- Central hidroeléctrica en las cercanías turbinando.

- Con antenas grandes (mayores de $1 \times 1 \mathrm{~m}$ ).

- Cuantas más antenas es más difícil configurar el equipo para una buena lectura.

- Los equipos multiplexer (una placa base que recoge la señal de 4 antenas) generan más problemas de configuración de las antenas que los equipos que cuentan con una placa base por antena. Sin embargo estos últimos requieren de conocimientos técnicos mayores para el montaje del equipo.

- Siempre que se utilice más de un equipo receptor es necesario sincronizar los equipos (seguir indicaciones del fabricante). Si no, las interferencias entre ambos son muy 
importantes, generan pérdidas de datos y pueden provocar daños en los equipos por sobrecalentamiento.

- Las fluctuaciones en el nivel de agua donde se ubican las antenas afecta al funcionamiento de las mismas, siendo necesario realizar ajustes de la configuración para mantener el rango de lectura.

$>$ Con un conocimiento a fondo del funcionamiento de los equipos PIT puede adaptarse el diseño a circunstancias muy diferentes con un coste económico relativamente bajo, principalmente en lo referente a las antenas, ya que pueden ser de fabricación propia con materiales económicos como cableado de cobre convencional y tubería de PVC. Sin embargo, sin dichos conocimientos, la puesta en funcionamiento y especialmente alcanzar una buena lectura de las antenas puede ser muy difícil y con una inversión en horas de trabajo para su configuración muy elevada.

- Análisis de datos:

El diseño de experimentos ideal y teórico puede plantearse con muestras balanceadas, pero es necesaria una flexibilidad tanto de los métodos estadísticos a aplicar como del propio diseño del estudio que permita adaptarse a variaciones al respecto. Como se ha comentado con anterioridad, es muy difícil obtener muestras de peces exactamente como las planteadas de forma teórica e ideal en un inicio.

El diseño de experimentos con más de un lote de individuos, así como la repetición de experimentos, permite ganar robustez estadística.

Las técnicas de análisis de supervivencia son complejas de comprender en profundidad, especialmente para estudios relacionados con la biología de los peces debido a que la bibliografía específica es escasa.

Las técnicas de análisis de supervivencia parecen ser las únicas que cuentan con herramientas adaptables a toda la casuística de peculiaridades con las que cuentan los resultados de estos trabajos.

Son pocos los softwares con potencia suficiente para ejecutar todo este tipo de análisis.

En la actualidad los más potentes son $\mathrm{SAS}^{\circledR}$ y R.

El software estadístico R es el que está contando con un mayor desarrollo al respecto de técnicas avanzadas en análisis de supervivencia. Son varias las publicaciones que en los últimos años han puesto a libre disposición diferentes paquetes, macros y código para estandarizar y facilitar su uso. 


\section{Relativas a posibles líneas de trabajo futuro}

A la vez que se han resuelto algunas cuestiones con los presentes estudios, también se han generado otras muchas dudas. Por ello, se ha considerado fundamental incluir entre las conclusiones generales las relativas a los aspectos entendidos como más importantes a profundizar a corto y medio plazo. Esta información creemos que es relevante para generar un documento de utilidad en el avance del conocimiento en este ámbito y que puede servir de motivación y desencadenante para otros grupos de investigación.

Estas son algunas de las líneas de trabajo futuro con posible interés:

Estudios similares comparando otras tipologías de pasos para peces, que en la actualidad están cobrando importancia, como son los pasos naturalizados (ríos artificiales y rampas de piedra principalmente).

D Estudio similares, especialmente de boga del Duero, debido a su estado actual de vulnerabilidad.

Ampliación de los estudios a otras especies endémicas o autóctonas de la Península Ibérica con movimientos migratorios de cierta importancia, como por ejemplo: cachos y bordallos (género Squalius), otras bogas (género Parachondrostoma) y otras especies de barbo (géneros Luciobarbus y Barbus).

Uso de las escalas de peces por parte de especies de pequeño tamaño como gobios, bermejuelas, piscardos, etc.

Efecto de los estanques o pozas de descanso en las escalas de peces.

Idoneidad de diferentes tipologías de entrada en escalas y las condiciones hidráulicas asociadas.

Relación entre el factor de forma (u otros parámetros morfológicos) y el comportamiento migratorio en las escalas.

Estudio del comportamiento y el uso de las escalas por parte de las especies exóticas, así como sus implicaciones en la gestión y manejo de las mismas.

Diferencias entre individuos salvajes y criados en piscifactoría.

Análisis de otros obstáculos físicos a la migración menos estudiados, como son algunas estaciones de aforo, caños de drenaje o descalces por cimentación en río.

Efecto de la rugosidad del lecho en los pasos de peces.

Desarrollo de sistemas automáticos de conteo de peces, idealmente con las siguientes características: 
- Continuos en el tiempo: que puedan recoger datos todo el año.

- Económicos.

- Basados en software y hardware libre.

- Resistentes a condiciones climáticas adversas.

- Con buen filtro automático de datos (diferenciar peces de otros elementos como palos, hojarasca, burbujas, etc.).

- Que permita tomar imágenes del pez.

- Que permita diferenciar entre movimientos ascendentes y descendentes.

- Que no requiera del marcaje de los peces.

- Que pueda funcionar con energía solar.

Desarrollo de sistemas de conexión remota con equipos de telemetría, idealmente con las siguientes características:

- Que permitan tanto el envío como la recepción de información alfanumérica.

- Económicos.

- Basados en software y hardware libre.

- No dependientes de cobertura telefónica.

- Que puedan funcionar con energía solar.

Desarrollo y aplicación de estándares de calidad en la construcción y evaluación de escalas para peces para la obtención de un Certificado de Buena Ejecución de Obra.

Ampliación del conocimiento sobre sistemas de aforo químico y su aplicación en pasos para peces: distancia de buena mezcla, precisión, comparativa con otros métodos, equipos y reactivos necesarios.

Análisis de la capacidad de salto de ciprínidos Ibéricos.

Análisis de obstáculos etológicos como por ejemplo tramos en oscuridad, aguas de desembalse a diferentes temperaturas y regulación de caudales para riego o producción hidroeléctrica.

Efecto del sistema de captura y marcaje en especies Ibéricas: forma de captura (pesca eléctrica, trampeo en escalas, redes de lanzado), anestesia (sí o no y diferentes anestesiantes: MS-222, aceite de clavo, electronarcosis, $\mathrm{CO}_{2}$ ) y tipo de marca (PIT tags, electromiagramas, radio tags, T-bar tags, implantes de elastómero, etc. Así como los diferentes tamaños).

Efecto de la manipulación en momentos clave como la reproducción. 
Estudio de dinámicas poblacionales de los ciprínidos Ibéricos en lo relativo a movimientos migratorios y fracciones móviles / estacionarias.

\section{Recomendaciones técnicas}

En este apartado se presentarán una serie de indicaciones que se consideran convenientes para poder alcanzar el objetivo de buen funcionamiento de escalas de peces de artesas. Se han extraído tanto de los experimentos específicos realizados para el presente trabajo como de los estudios similares realizados y de la multitud de obras visitadas en campo y sus observaciones:

Referentes al diseño de las obras

- Planos lo más detallados posibles, especialmente en lo referente a cotas de la obra.

- Máxima atención en el acotado del vertedero de entrada de agua.

- Anejos que especifiquen condiciones de buena ejecución y obligatoriedad de mantenimiento por parte de la titularidad de la obra si el marco normativo lo posibilita.

- Previsión de lecho con fondo rugoso.

- Ubicación de la escala en una de las márgenes o con acceso fácil para poder realizar obras de mantenimiento.

- Indicación clara de instalación de compuerta en la entrada de agua, así como detalle de sus dimensiones (hoja de cierre, tornillo sinfín y altura de soporte del volante) para asegurar tanto la apertura como el cierre por completo.

Referentes a la ejecución de las obras

- Dirección de obra especializada en escalas para peces y con seguimiento continuo.

- Sistemas de control de sedimentos y contaminantes vertidos.

- Comprobación de adecuación de cotas de la obra al centímetro, especialmente del vertedero de entrada de agua y del estanque más aguas abajo.

- Ejecución de la obra de aguas arriba a aguas abajo para evitar desniveles excesivos en la unión del estanque más elevado y la coronación del obstáculo.

- Comprobación de pendientes, evitando discontinuidades.

- En escalas con lecho rugoso controlar la colocación del mismo para que se asemeje lo más posible a un lecho natural, pero que quede fijado al fondo.

- Instalación de compuertas en la entrada de agua para poder realizar operaciones de control y mantenimiento dentro de la escala. 
- Previsión de guías laterales en el vertedero de más aguas abajo para poder colocar tajaderas y así controlar el salto de agua y por tanto la llamada en este punto.

- Aristas de las obras de hormigón en zonas de posible paso de peces romas o redondeadas.

- Sistema de derivación de elementos flotantes que los alejen de la entrada de agua de la escala.

- Comprobación detallada de la obra antes de la retirada de ataguía y maquinaria para que las posibles modificaciones no afecten en gran medida el presupuesto.

- Cartelería indicativa de prohibición de pesca en la escala, así como en sus proximidades si el marco normativo lo especifica.

- Cartelería divulgativa explicando los objetivos de la obra.

Referentes al mantenimiento de las obras

- Revisión y limpieza de los estanques al menos con una periodicidad anual y/o posterior a periodos de crecida. En escalas con orificios de fondo asegurar la limpieza de los mismos para el buen vaciado de los estanques y para facilitar su uso por los peces que lo deseen.

- Comprobar que circula agua por la escala y que se corresponde con el estipulado en el contrato o concesión.

- En épocas de migración inspecciones visuales para comprobar que los individuos no se salen de la escala, especialmente en pasos donde los peces necesitan saltar para superar los estanques.

- Comprobar que los posibles descalces de la obra aguas abajo no dejan el primer estanque descolgado e inaccesible. 


\section{BIBLIOGRAFÍA GENERAL}

En este apartado solo se incluirá la bibliografía utilizada para justificar los apartados generales de esta tesis, contando cada apartado de resultados con su bibliografía específica detallada.

Alexandre C., Quintella B.R., Silva A., Mateus C., Romão F., Branco P., Ferreira M.T. and Almeida P.R. 2013. Use of electromyogram telemetry to assess the behavior of the Iberian barbel (Luciobarbus bocagei Steindachner, 1864) in a pool-type fishway. Ecological Engineering 51: 191-202.

Allison P.D. 2010. Survival analysis using SAS: a practical guide. Sas Institute.

Beach M. A. 1984. Fish pass design. Ministry of Agriculture, Fisheries and Food. Fisheries Research Technical Report, 78.

Bermúdez M., Puertas J., Cea L., Pena L., and Balairón L. 2010. Influence of pool geometry on the biological efficiency of vertical slot fishways. Ecological Engineering, 36(10), 1355-1364.

Branco, P., Santos, J. M., Katopodis, C., Pinheiro, A., and Ferreira, M. T. (2013). Pool-type fishways: two different morpho-ecological cyprinid species facing plunging and streaming flows. PloS one, 8(5), e65089.

Cardoso G.R. 2015. Monitorização da passagem para peixes do açude-ponte em Coimbra: otimização da metodologia de contagem. Dissertaçao, Escola de Ciências e tecnologia, Universidade de Évora.

Castro-Santos T. 2012. Adaptive fishway design: a framework and rationale for effective evaluations. Herstellung der ökologischen Durchgängigkeit der Bundeswasserstraßen: 76.

CHD. 2014. Propuesta de proyecto de revisión del plan hidrológico de la parte española de la demarcación hidrográfica del Duero (2015-2021). Anejo 7: inventario de presiones. Confederación Hidrográfica del Duero.

Clay, C. H. 1995. Design of Fishways and Other Fish Facilities. Lewis Publishers. Ann Arbor, MI.

Cooke S.J., Wilson A.D., Elvidge C.K., Lennox R.J., Jepsen N., Colotelo A.H., and Brown R.S. 2015. Ten practical realities for institutional animal care and use committees when evaluating protocols dealing with fish in the field. Reviews in Fish Biology and Fisheries, 1-11.

Council E., 1986. EEC Council Directive 86/609/EEC of 24 November 1986 on the approximation of laws, regulations and administrative provisions of the Member States regarding the protection of animals used for experimental and other scientific purposes. 358, $1-28$. 
DFG. 2005. Seguimiento de dispositivos de paso para fauna piscícola en obras realizadas por la Diputación Foral de Guipuzkoa año 2005. Departamento para el Desarrollo Sostenible, Diputación Foral de Guipuzkoa.

DFG. 2006. Seguimiento de dispositivos de paso para fauna piscícola en obras realizadas por la Diputación Foral de Guipuzkoa año 2006. Departamento para el Desarrollo Sostenible, Diputación Foral de Guipuzkoa.

DFG. 2008. Seguimiento de los dispositivos de franqueo en los azudes de Garaiko-Errota (Leitzarán) y Txarama (Araxes) en la cuenca del Oria. Departamento para el Desarrollo Sostenible, Diputación Foral de Guipuzkoa.

FAO/DVWK. 2002. Fish passes-Desing, dimensions and monitoring.: Roma, Fao.

Fuentes-Pérez J.F., Sanz-Ronda F.J., de Azagra Paredes A.M., and García-Vega A. 2014. Modeling Water-Depth Distribution in Vertical-Slot Fishways under Uniform and Nonuniform Scenarios. Journal of Hydraulic Engineering.

Fuentes-Pérez J. F., Sanz-Ronda F. J., de Azagra A. M., and García-Vega A. 2016. Non-uniform hydraulic behavior of pool-weir fishways: $A$ tool to optimize its design and performance. Ecological Engineering, 86, 5-12.

Hosmer D., Lemeshow S. and May S. 2008. Applied survival analysis: Regression modeling of time to event data. Wiley-Interscience. Hoboken, NJ.

Kleinbaum D.G. and Klein M. 2012. Survival analysis. A self-learning text book. Springer.

Larinier, M. 2002. Pool fishways, pre-barrages and natural bypass channels. Bulletin Français de la Pêche et de la Pisciculture, 364(suppl), 54-82.

Martínez de Azagra A. 1999. Escalas para peces. Publicaciones ETSII. AA, (26), 35.

Puertas J., Cea L., Bermúdez M., Pena L., Rodríguez A., Rabuñal J. R., Balairón L., Lara A. and Aramburu E. 2012. Computer application for the analysis and design of vertical slot fishways in accordance with the requirements of the target species. Ecological Engineering 48: 51-60

Rajaratnam N., Van der Vinne G., and Katopodis C. 1986. Hydraulics of vertical slot fishways. Journal of Hydraulic Engineering, 112(10), 909-927.

Rajaratnam N., Katopodis C., and Mainali A. 1989. Pool-orifice and pool-orifice-weir fishways. Canadian Journal of Civil Engineering, 16(5), 774-777.

Rocaspana-Jové R., Aparicio-Manau E. and Palau-Ibars A. 2012. Análisis del uso, la eficiencia y la necesidad del paso para peces en el azud de Salinas (río Cinca, Huesca). Informe Técnico. Dirección de Medio Ambiente y Desarrollo Sostenible, Endesa. 
Santos J. M., Silva A., Katopodis C., Pinheiro P., Pinheiro A., Bochechas J. and Ferreira M. T. 2012. Ecohydraulics of pool-type fishways: getting past the barriers. Ecological Engineering, 48, 38-50.

Sanz-Ronda F. J., Bravo-Córdoba, F. J., Fuentes-Pérez J. F., Ruiz-Legazpi J., García-Vega A., Ramos N., Salgado-González V.M. and Martínez de Azagra, A. 2013. Pasos para peces: escalas y otros dispositivos de paso. Notas técnicas del CIREF, 7, 17.

Silva A.T., Santos J.M., Franco A.C., Ferreira M.T., Pinheiro A.N. 2009. Selection of Iberian barbel Barbus bocagei (Steindachner, 1864) for orifices and notches upon different hydraulic configurations in an experimental pool-type fishway. Journal of Applied Ichthyology 25: 173177.

Silva A.T., Santos J.M., Ferreira M.T., Pinheiro A.N., Katopodis C. 2011. Effects of water velocity and turbulence on the behaviour of Iberian barbel (Luciobarbus bocagei, Steindachner 1864) in an experimental pool-type fishway. River Research and Applications 27: 360-373.

Silva A.T., Katopodis C., Santos J.M., Ferreira M.T., Pinheiro A.N. 2012. Cyprinid swimming behaviour in response to turbulent flow. Ecological Engineering 44: 314-328.

URS. 2010. Evaluación de la efectividad de la escala de dpeces del azud del río Ebro en Xerta (Tarragona). Informe técnico, United Research Services España, S.L. 


\section{ANEJO I: Aceptación de los coautores}

A continuación se presenta la aceptación de los diferentes coautores de los capítulos aquí presentados como Resultados I, II y III, dando su consentimiento expreso a que sean utilizados para la presente tesis y renunciando a utilizarlos como parte de otras tesis. 
D/Dña Juan Francisco Fuentes Pérez, con DNI/Pasaporte no 78880235-X como coautor de las publicaciones los capítulos

- Ascent ability of Brown trout, Salmo trutta, and two Iberian cyprinids - Iberian barbel, Luciobarbus bocagei, and Northern straight-mouth nase, Pseudochondrostoma duriense- in a vertical slot fishway.

Doy mi consentimiento para que formen parte de la Tesis Doctoral presentada en la Universidad de Valladolid por:

D/Dña Francisco Javier Bravo Córdoba, y titulada Evaluación Biológica de Escalas de Artesas para Algunas de las Principales Especies de Peces Ibéricos,

Así mismo renuncio a la presentación de dichos capítulos como parte de otra tesis doctoral.

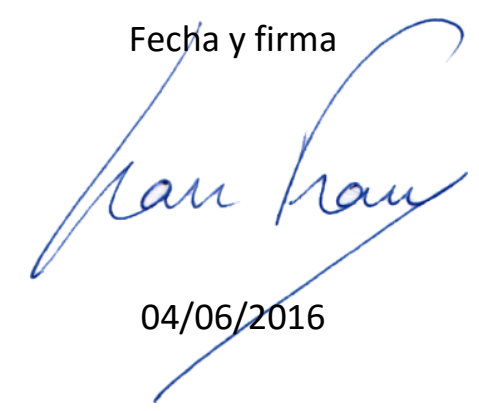


D/Dña Leandro Fernandes Celestino, con DNI/Pasaporte no FM856118 como coautor de los capítulos

Fishway with two entrance branches: understanding its performance for Iberian barbel, luciobarbus bocagei (Steindachner, 1864).

Doy mi consentimiento para que formen parte de la Tesis Doctoral presentada en la Universidad de Valladolid por:

D/Dña Francisco Javier Bravo Córdoba, y titulada Evaluación Biológica de Escalas de Artesas para Algunas de las Principales Especies de Peces Ibéricos,

Asi mismo renuncio a la presentación de dichos capítulos como parte de otra tesis doctoral.

$$
\begin{aligned}
& \text { Leonoho temondes Celestino. } \\
& \text { Fecha y firma }
\end{aligned}
$$


D/Dña Sergio Makrakis, con DNI/Pasaporte no FB360490 como coautor de los capítulos

- Selecting the best technical fishway design for Iberian barbel, Luciobarbus bocagei (Steindachner, 1864): vertical slots versus submerged notches with bottom orifice.

- Fishway with two entrance branches: understanding its performance for Iberian barbel, luciobarbus bocagei (Steindachner, 1864).

Doy mi consentimiento para que formen parte de la Tesis Doctoral presentada en la Universidad de Valladolid por:

D/Dña Francisco Javier Bravo Córdoba, y titulada Evaluación Biológica de Escalas de Artesas para Algunas de las Principales Especies de Peces Ibéricos,

Así mismo renuncio a la presentación de dichos capítulos como parte de otra tesis doctoral.

Toledo (Brasil), 7 junio 2016

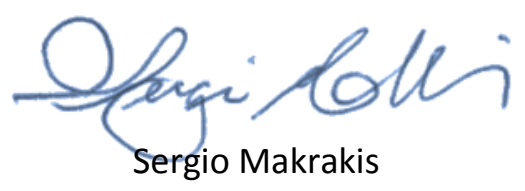


D/Dña Jorge Valbuena Castro, con DNI no 71138549-D como coautor de los capítulos

- Selecting the best technical fishway design for Iberian barbel, Luciobarbus bocagei (Steindachner, 1864): vertical slots versus submerged notches with bottom orifice.

Doy mi consentimiento para que formen parte de la Tesis Doctoral presentada en la Universidad de Valladolid por:

D/Dña Francisco Javier Bravo Córdoba, y titulada Evaluación Biológica de Escalas de Artesas para Algunas de las Principales Especies de Peces Ibéricos,

Asi mismo renuncio a la presentación de dichos capítulos como parte de otra tesis doctoral.

Fecha y firma

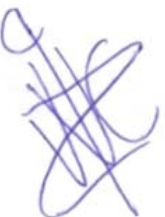

7 de Junio de 2016 
A continuación se presenta la aceptación de los diferentes coautores de los capítulos aquí presentados, dando su consentimiento a que sean utilizados para la presente tesis y renunciando a utilizarles como parte de otras tesis.

D/Dña Francisco Javier Sanz Ronda, con DNI/Pasaporte no 15398294R como coautor de los capítulos

- Ascent ability of Brown trout, Salmo trutta, and two Iberian cyprinids -Iberian barbel, Luciobarbus bocagei, and Northern straight-mouth nase, Pseudochondrostoma duriense- in a vertical slot fishway.

- Selecting the best technical fishway design for Iberian barbel, Luciobarbus bocagei (Steindachner, 1864): vertical slots versus submerged notches with bottom orifice.

- Fishway with two entrance branches: understanding its performance for Iberian barbel, LLuiobarbus bocagei (Steindachner, 1864).

Doy mi consentimiento para que formen parte de la Tesis Doctoral presentada en la Universidad de Valladolid por:

D/Dña Francisco Javier Bravo Córdoba, y titulada Evaluación Biológica de Escalas de Artesas para Algunas de las Principales Especies de Peces Ibéricos,

Así mismo renuncio a la presentación de dichos capítulos como parte de otra tesis doctoral.

Palencia, 10 de junio de 2016.

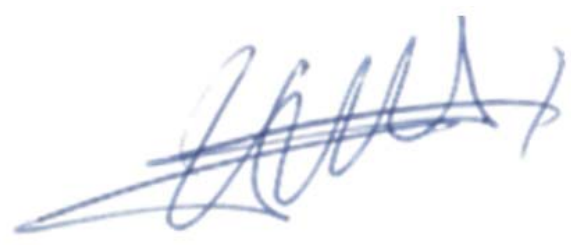

Fdo.: Fco. Javier Sanz Ronda 
D/Dña Theodore Castro-Santos, con DNI/Pasaporte no S01576065 como coautor de los capítulos

- Ascent ability of Brown trout, Salmo trutta, and two Iberian cyprinids - Iberian barbel, Luciobarbus bocagei, and Northern straight-mouth nase, Pseudochondrostoma duriense- in a vertical slot fishway.

Doy mi consentimiento para que formen parte de la Tesis Doctoral presentada en la Universidad de Valladolid por:

D/Dña Francisco Javier Bravo Córdoba, y titulada Evaluación Biológica de Escalas de Artesas para Algunas de las Principales Especies de Peces Ibéricos,

Así mismo renuncio a la presentación de dichos capítulos como parte de otra tesis doctoral.

Fecha y firma

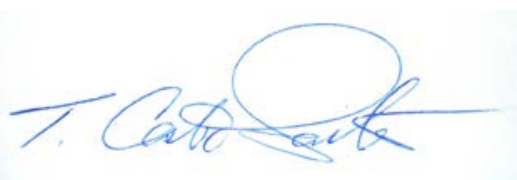

7 Junio, 2016 
D/Dña Jorge Ruiz Legazpi, con DNI/Pasaporte no 71930325-X como coautor de los capítulos

- Fishway with two entrance branches: understanding its performance for Iberian barbel, luciobarbus bocagei (Steindachner, 1864).

- Selecting the best technical fishway design for Iberian barbel, Luciobarbus bocagei (Steindachner, 1864): vertical slots versus submerged notches with bottom orifice.

Doy mi consentimiento para que formen parte de la Tesis Doctoral presentada en la Universidad de Valladolid por:

D/Dña Francisco Javier Bravo Córdoba, y titulada Evaluación Biológica de Escalas de Artesas para Algunas de las Principales Especies de Peces Ibéricos,

Asi mismo renuncio a la presentación de dichos capítulos como parte de otra tesis doctoral.

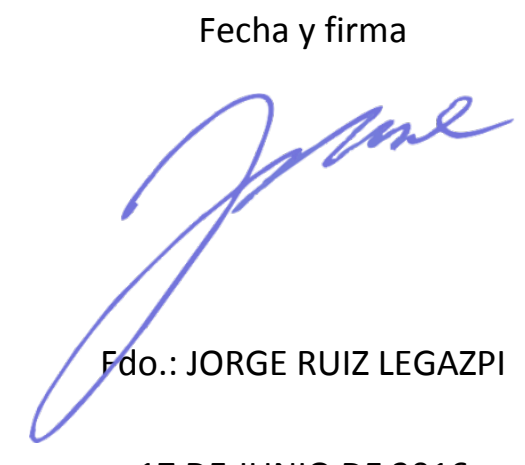

17 DE JUNIO DE 2016 
ANEJO II: Copia de la publicación del apartado Resultados I 


\title{
Ascent ability of brown trout, Salmo trutta, and two Iberian cyprinids - Iberian barbel, Luciobarbus bocagei, and northern straight-mouth nase, Pseudochondrostoma duriense - in a vertical slot fishway
}

\author{
F.J. Sanz-Ronda ${ }^{1, \star}$, F.J. Bravo-Córdoba ${ }^{1}$, J.F. Fuentes-Pérez ${ }^{1}$ and T. Castro-Santos ${ }^{2}$ \\ 1 U. D. de Hidráulica e Hidrología, Grupo de Ecohidráulica Aplicada (GEA-ecohidraulica.org), Departamento de Ingeniería Agrícola \\ y Forestal, E.T.S.II.AA. Universidad de Valladolid, Avda. Madrid, 44, 34004 Palencia, Spain \\ 2 S.O. Conte Anadromous Fish Research Center, USGS-Leetown Science Center, P.O. Box 796, One Migratory Way, Turners Falls, MA 01376
}

Received July 31, 2015 - Revised November 16, 2015 - Accepted December 9, 2015

\begin{abstract}
Passage performance of brown trout (Salmo trutta), Iberian barbel (Luciobarbus bocagei), and northern straight-mouth nase (Pseudochondrostoma duriense) was investigated in a vertical slot fishway in the Porma River (Duero River basin, Spain) using PIT telemetry. We analysed the effects of different fishway discharges on motivation and passage success. Both cyprinid species ascended the fishway easily, performing better than the trout despite their theoretically weaker swimming performance. Fishway discharge affected fish motivation although it did not influence clearly on passage success. Observed results can guide design and operation criteria of vertical slot fishways for native fish.
\end{abstract}

Key-words: Iberian fish / vertical slot fishway / fish passage / motivation / transit time

\begin{abstract}
Résumé - Aptitude au passage de la truite, Salmo trutta, et de deux cyprinidés ibériques, le barbeau ibérique, Luciobarbus bocagei, et le nase à bouche droite, Pseudochondrostoma duriense dans une passe à poissons à fentes verticales. La performance de passage de la truite (Salmo trutta), du barbeau ibérique (Luciobarbus bocagei), et du nase à bouche droite (Pseudochondrostoma duriense) a été étudiée dans une passe à fentes verticales dans la rivière Porma (bassin de la rivière Douro, Espagne) en utilisant la technologie PIT. Nous avons analysé les effets de différents débits dans la passe à poissons sur la motivation et la réussite de passage. Les deux espèces de cyprinidés montaient la passe facilement, étaient plus performantes que les truites, malgré leur performance de nage théoriquement plus faible. Le débit dans la passe affectait la motivation des poissons bien qu'il n'ait pas influencé clairement le succès de passage. Les résultats observés peuvent guider dans les critères de conception de passes à fentes verticales pour les poissons indigènes.
\end{abstract}

Mots-clés : Poissons ibérique / passe à fente verticale / passage des poissons / motivation / temps de transit

\section{Introduction}

The potamodromous fish fauna of the Iberian Peninsula is mostly composed of rheophylic cyprinids. Among the most common of these are the Iberian barbel (Luciobarbus bocagei Steindachner, herafter referred to as 'barbel'), and Northern straight-mouth nase (Pseudochondrostoma duriense Coelho; hereafter referred to as 'nase') and their close relatives (Doadrio, 2001). They occupy a range of riverine habitats, from floodplains to headwaters and often co-occur with brown trout (Salmo trutta L.). Like many cyprinids, barbel and nase usually ascend to headwaters to spawn in spring.

\footnotetext{
^ Corresponding author: jsanz@iaf.uva.es
}

In Iberia, many cyprinids are local endemics and have IUCN (International Union for Conservation of Nature) protection status. Iberian barbel is listed as "least concern"; nase is more threatened, being categorized as "vulnerable" and it is mentioned on Annex II of the European Union Habitats Directive (92/43/EEC). Barriers to movement block access to essential habitat and are among the principal threats affecting these communities (Doadrio et al., 2011).

Fishway design recommendations usually distinguish between salmonids and a large group of fish, often called "others", "non salmonids", "weak swimmers", "white fish", or "coarse fish" (Alexandre et al., 2013; Mallen-Cooper, 1999; Mateus et al., 2008). 


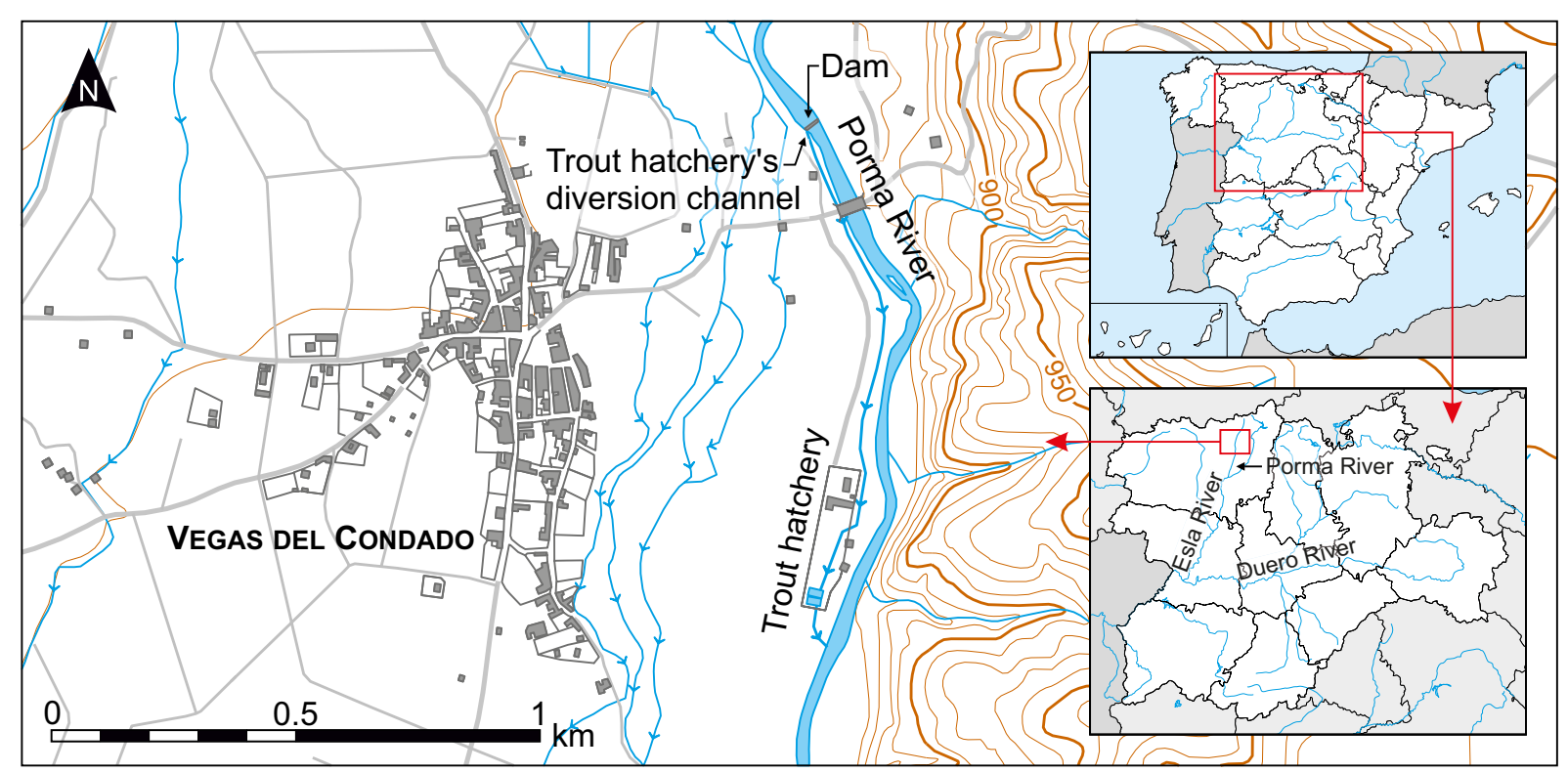

Fig. 1. Study site location: Porma River, Castilla y León region (Northwest Spain).

Fish passes for salmonids are designed with higher slope or drop per pool than for other fish (Larinier, 2002a). This is because salmonids are widely assumed to be comparatively strong and motivated swimmers. This assumption is founded on very few data, however, and recent studies suggest that other freshwater species may be as strong or stronger swimmers than salmonids (Castro-Santos, 2005; Pompeu and Martinez 2007; Castro-Santos et al., 2013; Sanz-Ronda et al., 2015).

One of the most popular fishway designs in Spain is the vertical slot fishway. The design was originally developed for salmonid passage (Clay, 1995), but is increasingly favored for a variety of species, including cyprinids (Sanz-Ronda et al., 2010).

Vertical slot fishways were initially designed to accommodate large fluctuations in upstream and downstream water levels while maintaining constant such hydraulic factors as energy dissipation rate and velocity (Rajaratnam et al., 1986; Larinier, 2002b; Rodríguez et al., 2006; Wang et al., 2010). They have other advantages, though, notably that the slots offer passage opportunities throughout the water column, and are thought to be compatible with a broad range of species (Stuart and Berghuis, 2002; Mallen-Cooper and Brand, 2007; White et al., 2010).

Recent compilations of passage performance, however, have raised serious questions about the effectiveness of the design, which ranged from 0\%-100\% (Bunt et al., 2011; Noonan et al., 2012).

The reason for this variation in performance is poorly understood, and there is a need for rigorous biological evaluation of fish ladders if hydraulic designs are to be improved (CastroSantos et al., 2009; Bunt et al., 2011; Cooke and Hinch, 2013).

Recent efforts to establish standardized passage metrics based on movement theory have yet to be widely adopted (Castro-Santos et al., 2009; Castro-Santos and Haro, 2010; Castro-Santos and Perry, 2012; Cooke and Hinch, 2013). By explicitly measuring rates of movement and failure as fish ap- proach, enter, and pass numerous fishways of various designs it will become possible to better understand why and to what extent some fishways perform better than others (Travade and Larinier, 2002; Bunt et al., 2011).

Passage performance results from interactions between the structural and hydraulic features of each fishway, fish behavior, and swimming ability (Makrakis et al., 2010). Behavior and swimming performance are in turn affected by environmental parameters like temperature, turbidity, dissolved oxygen, etc. and biological parameters like species, age, sex or physiological status (James and Johnston, 1998; Plaut, 2002; Clough et al., 2004; Pedersen et al., 2008).

There are few published studies of passage performance of Iberian fishes. Most of the existing work was performed in laboratory settings and focused on the hydraulic preferences of fish within pool-type fish ladders (Silva et al., 2009; Silva et al., 2012; Branco et al., 2013). The relevance of these data to field conditions is not well-established, however, and more work is needed to verify the principles learned in the laboratory (Thiem et al., 2013).

The purpose of this paper is to evaluate the passage performance of native brown trout, Iberian barbel and northern straight-mouth nase ascending a vertical slot fishway in field conditions and under different flow regimes.

\section{Methods}

\subsection{Study site}

The experiments were carried out in the Porma River (part of the Duero River watershed), in the village of Vegas del Condado, (province of León in Northwest Spain; 42 $41^{\prime} 17.40^{\prime \prime} \mathrm{N}$; 5' 21' 27.26" W; Figure 1). The river drains a watershed of $1146 \mathrm{~km}^{2}$ with mean annual discharge of about $25 \mathrm{~m}^{3} \cdot \mathrm{s}^{-1}$. It is strongly regulated for irrigation and during spring and summer discharge is higher and water temperature is lower than under natural conditions. 


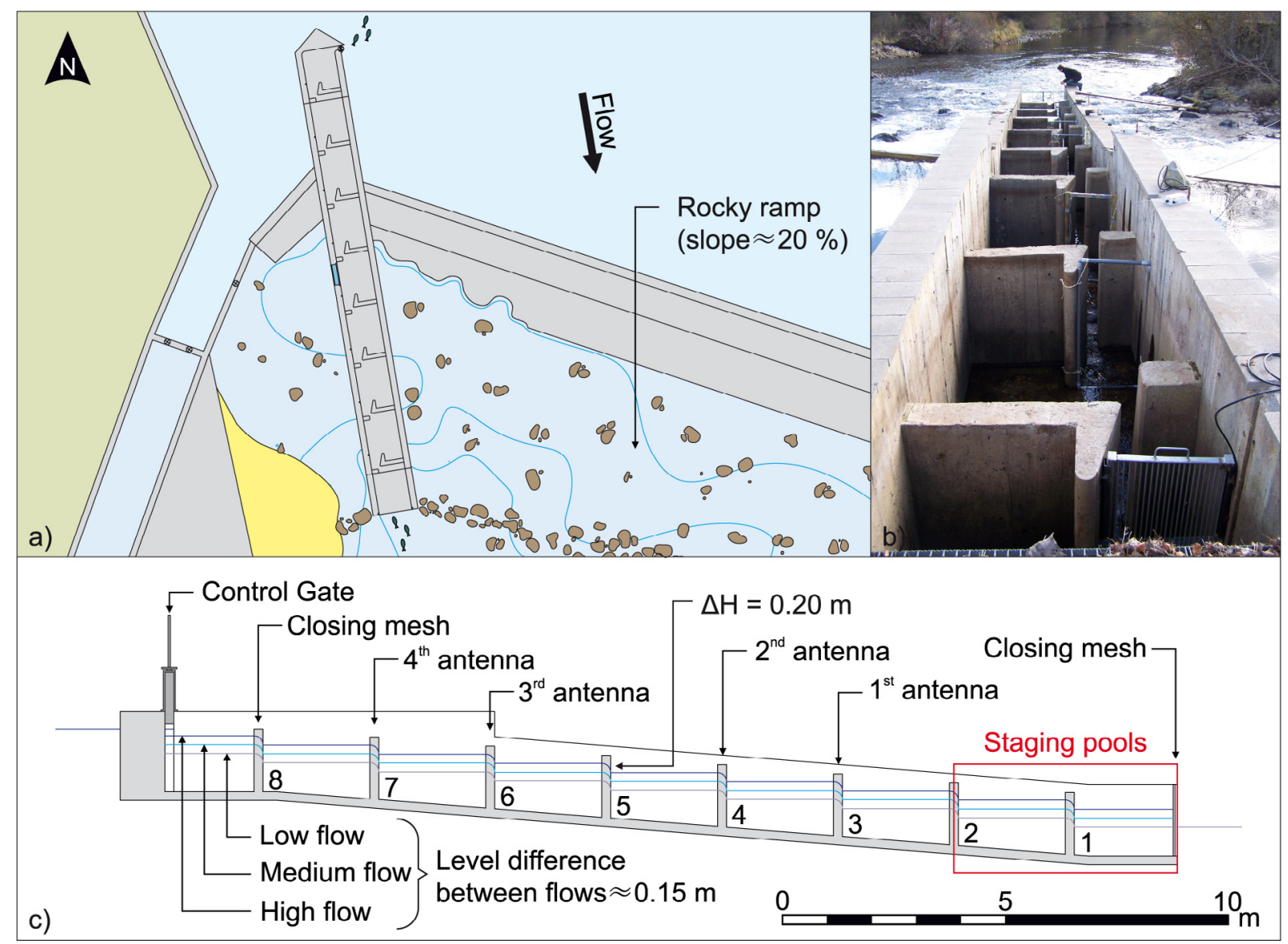

Fig. 2. (a) Plan view of fishway site location at the dam. (b): Antennas and top closing mesh installation. (c) longitudinal scheme of the experimentation design.

The reach under study belongs to the metarhitron area with an average altitude of about $860 \mathrm{~m}$ above sea level. The zone corresponds to a C4 category (gravel-bed stream of moderate sinuosity with a slope of $0.001-0.02 \mathrm{~m} / \mathrm{m}$; (Rosgen and Silvey, 1996), and the most abundant fish species are brown trout, Iberian barbel, northern straight-mouth nase and Northern Iberian chub (Squalius carolitertii Doadrio), all of them native and potamodromous fish.

In 1986 a gravity dam ( $1.80 \mathrm{~m}$ high by $35 \mathrm{~m}$ wide) was built. To mitigate the habitat fragmentation caused by the dam, a straight vertical-slot fishway was built in 2009 on the right bank of the dam (Figure 2). The length of the fish ladder is $24 \mathrm{~m}$ with a mean slope of $7.7 \%$ (range: $7.1 \%-9.4 \%$ ). The design flow is $0.350 \mathrm{~m}^{3} \cdot \mathrm{s}^{-1}$, with 9 pools of $2.4 \mathrm{~m}$ long $\times 1.6 \mathrm{~m}$ wide and an average water depth of $1.1 \mathrm{~m}$. The drop between pools is $0.2 \mathrm{~m}$. The width of the slots is $0.2 \mathrm{~m}$ and the water velocity through them is variable depending on the flow and the local bottom slope (Table 2). The volumetric energy dissipated is between 180 and $190 \mathrm{~W} \cdot \mathrm{m}^{-3}$, depending on river discharge. The bottom of the structure is covered by substrate from the riverbed to increase roughness. The uppermost weir (fishway exit) has a sluice gate that is used to regulate flow within the fishway.

Water temperature (Orpheus Mini, OTT Hydromet GmbH) and water oxygen saturation (PCD-650 portable oximeter ${ }^{\circledR}$ ) were monitored throughout the day at 30 min intervals. Suspended sediments were collected three times daily and analyzed in the laboratory using gravimetric methods.

\subsection{Fish testing}

We used a passive integrated transponder (PIT)-tag and antenna system to study fish behavior (Castro-Santos et al., 1996; Franklin et al., 2012).

Fish were caught by electrofishing (Erreka model; $2200 \mathrm{~W}$, 5 A) one day prior to testing. They were captured trying to pass a chute, close to the tail of the small reservoir formed by the dam $-500 \mathrm{~m}$ upstream of the fish ladder- in an apparent status of movement activity. All fish were tagged with PITtags, (Half-duplex tags measuring $23 \mathrm{~mm}$ long by $3.85 \mathrm{~mm}$ diameter, $0.6 \mathrm{~g}$ : TIRIS model RI-TRP-WRHP; Texas Instruments, Dallas, Texas, USA). They were anaesthetized with a solution of $0.10 \mathrm{~g} \cdot \mathrm{L}^{-1} \mathrm{MS}-222$ and tagged intraperitoneally by making an incision posterior to the left pectoral fin and gently inserting the tag into the peritoneal cavity (Castro-Santos and Vono, 2013). No fish died during or after the marking process. This method has been shown to have negligible effects on growth, survival, and behavior of many species (Ostrand et al., 2011; Ficke et al., 2012). 
Table 1. Date, time and flow rate of the trials for the species under study. Hours are in solar time (12:00 h coincides with the highest sun elevation).

\begin{tabular}{|l|c|c|c|c|c|c|}
\cline { 2 - 7 } \multicolumn{1}{c|}{} & \multicolumn{2}{c|}{ First test } & \multicolumn{2}{c|}{ Second test } & \multicolumn{2}{c|}{ Third test } \\
\cline { 2 - 7 } \multicolumn{1}{c|}{} & Trout & Barbel \& Nase & Trout & Barbel \& Nase & Trout & Barbel \& Nase \\
\hline Start date & $11 / 26 / 2010$ & $05 / 31 / 2011$ & $11 / 29 / 2010$ & $06 / 02 / 2011$ & $12 / 01 / 2010$ & $06 / 04 / 2011$ \\
Start solar time & $14: 30 \mathrm{~h}$ & $08: 00 \mathrm{~h}$ & $12: 30 \mathrm{~h}$ & $08: 00 \mathrm{~h}$ & $16: 30 \mathrm{~h}$ & $08: 00 \mathrm{~h}$ \\
\cline { 2 - 7 } Discharge flow & Medium $\left(0.334 \pm 0.006 \mathrm{~m}^{3} \cdot \mathrm{s}^{-1}\right)$ & \multicolumn{2}{c|}{$\operatorname{High}\left(0.402 \pm 0.006 \mathrm{~m}^{3} \cdot \mathrm{s}^{-1}\right)$} & Low $\left(0.245 \pm 0.005 \mathrm{~m}^{3} \cdot \mathrm{s}^{-1}\right)$ \\
\hline
\end{tabular}

Table 2. Cumulative height, local slope between pools and mean water velocity within the slots under three different flow tests (see Figure 1). Slots are numbered from bottom to top.

\begin{tabular}{|l|c|c|c|c|c|}
\hline \multirow{2}{*}{$\begin{array}{l}\text { Slot } \\
\text { (Antenna) }\end{array}$} & $\begin{array}{c}\text { Cumulative } \\
\text { height }\end{array}$ & \multirow{2}{*}{$\begin{array}{c}\text { Slope } \\
(\%)\end{array}$} & \multicolumn{3}{|c|}{ Mean water velocity $\left(\mathrm{m} \cdot \mathrm{s}^{-1}\right)$} \\
\cline { 4 - 6 } & $(\mathrm{m})$ & & $\begin{array}{c}\text { Low flow } \\
\left(0.245 \mathrm{~m}^{3} \cdot \mathrm{s}^{-1}\right)\end{array}$ & $\begin{array}{c}\text { Medium flow } \\
\left(0.245 \mathrm{~m}^{3} \cdot \mathrm{s}^{-1}\right)\end{array}$ & $\begin{array}{c}\text { High flow } \\
\left(0.245 \mathrm{~m}^{3} \cdot \mathrm{s}^{-1}\right)\end{array}$ \\
\hline $\mathbf{3 ( 1 )}$ & 0.19 & 7.14 & 1.45 & 1.77 & 1.81 \\
$\mathbf{4 ( 2 )}$ & 0.40 & 8.24 & 1.59 & 1.79 & 1.87 \\
$\mathbf{5 ( - )}$ & 0.58 & 6.70 & 1.64 & 1.89 & 1.94 \\
$\mathbf{6 ( 3 )}$ & 0.82 & 9.41 & 1.82 & 1.96 & 2.08 \\
$\mathbf{7 ( 4 )}$ & 1.01 & 6.94 & 1.60 & 1.75 & 1.87 \\
\hline
\end{tabular}

Fish were then transferred to the staging area (Figure 1), where they immediately recovered swimming and orientation capacities. Fish were allowed to acclimate to their new environment for $24 \mathrm{~h}$ before starting the experiment. The density of fish in this pool was $0.75 \mathrm{~kg} \cdot \mathrm{m}^{-3}$ for trials with trout and $1.22 \mathrm{~kg} \cdot \mathrm{m}^{-3}$ for trials with barbel and nase (both species were combined in the same pool). After the experiments, fish were sacrificed following the ethical guidelines of the EU legislation (Council, 1986).

\subsection{Ascent efficiency}

Antennas were placed in all except for the middle slot, and each antenna was connected to a dedicated reader (ORFID ${ }^{\circledR}$ Half Duplex reader with antenna Multiplexer, Figure 2 and Table 1), programmed to interrogate the antennas at $14 \mathrm{~Hz}$ ( $3.5 \mathrm{~Hz}$ or $0.29 \mathrm{~s}$ per antenna). Fish were confined within the study section of the fishway by closing off the lowermost and uppermost slots with wire mesh. Once fish were introduced into the staging area they were allowed to rest for $24 \mathrm{~h}$. A second mesh screen was placed at the upstream end of the staging area to prevent fish from ascending the fishway during this period. Just before each experiment, the flow gate was opened up to achieve the desired water level in and discharge through the fishway. Once desired conditions were established, the mesh at the upstream end of the staging area was removed and fish were allowed to ascend the fishway volitionally.

Brown trout testing was carried out about two weeks before spawning and during a period when this species exhibits strong migratory activity in this area. Similar criteria were used for barbel and nase. Each species was subject to three trials, each lasting $24 \mathrm{~h}$ and performed under different flow conditions. Fish were not fed during experiments, although they could find some food in the fishway bottom and drifting in the current.

\subsection{Data analysis}

\subsubsection{Onset of movement}

During each trial, fish were able to make several ascents; once a fish reached the upper limit of the fishway or its maximum ascent distance it usually descended again to the resting pool, from where they tried to ascend again, thus accounting for several attempts. Attempts were not considered valid unless the fish was detected at least at Antenna 2, to separate exploratory movements from ascending movements. The last detection at Antenna 1 is considered as the start time of the attempt. Attempts in which fish were detected at the antenna furthest upstream were deemed "successful"; otherwise, they were deemed "failures".

\subsubsection{Motivation analysis}

We quantified ascent motivation using three methods, evaluating the effects on each of flow discharge. The three methods were: (1) whether or not each fish made any attempts - analyzed using the logistic regression and compared in pairs with the chi-square test of independence; (2) the number of attempts staged by those fish that tried to ascend - analyzed using a oneway analysis of variance (ANOVA), with a Tukey's HSD test and compared with a multiple-range test; and (3) the attempt rate.

Attempt rate was included in the analysis as an indicator of motivation, and was quantified using survival analysis (stratified proportional hazard model; (Castro-Santos, 2004)). For those fish that staged at least one attempt, the time between the start of the trial and the first detection constituted the first attempt time, resulting in an uncensored observation. Subsequent attempt times were the time between the start of the attempt and the start of the previous attempt. The time between the start of the last attempt and the end of the trial was a censored observation. Fish that did not stage any attempt were 
Table 3. Biological and environmental conditions. Sequence indicates the order in which trials were performed. Sample size (n) as total number of attempts and available fish (between parentheses), number of fish that staged attempts within each trial (Attempting), and total number of attempts staged (Attemptstot) for each species-treatment combination. Condition Factor (CF) $=100 \cdot \mathrm{M} \cdot \mathrm{FL}^{-3}$ (M: mass (g); FL: Fork Length $(\mathrm{cm})$ ). (mean $\pm \mathrm{SD})$.

\begin{tabular}{|c|c|c|c|c|c|c|c|c|}
\hline \multirow[t]{2}{*}{ Species } & \multirow[t]{2}{*}{ Flow rate } & \multirow[t]{2}{*}{ Sequence } & \multirow[t]{2}{*}{ Attempting } & \multirow[t]{2}{*}{ Attemptstot } & \multicolumn{2}{|c|}{$\begin{array}{l}\text { Fork length } \\
\text {-FL- mm }\end{array}$} & \multicolumn{2}{|c|}{$\begin{array}{l}\text { Condition Factor } \\
-\mathrm{CF}-\mathrm{g} \cdot \mathrm{cm}^{-3}\end{array}$} \\
\hline & & & & & Male & Female & Male & Female \\
\hline \multirow{3}{*}{$\begin{array}{l}\text { Brown trout } \\
n=32(20)\end{array}$} & Low & 3 & 4 & 5 & & & & \\
\hline & Medium & 1 & 8 & 11 & $219.5 \pm 32.8$ & $223.2 \pm 36.5$ & $1.14 \pm 0.0$ & $1.15 \pm 0.1$ \\
\hline & High & 2 & 11 & 16 & & & & \\
\hline \multirow{3}{*}{$\begin{array}{l}\text { Barbel } \\
n=106(17)\end{array}$} & Low & 3 & 9 & 26 & & & & \\
\hline & Medium & 1 & 10 & 54 & $241.8 \pm 58.2$ & $250.3 \pm 46.9$ & $1.50 \pm 0.1$ & $1.42 \pm 0.0$ \\
\hline & High & 2 & 9 & 26 & & & & \\
\hline \multirow{3}{*}{$\begin{array}{l}\text { Nase } \\
n=31(8)\end{array}$} & Low & 3 & 3 & 8 & & & & \\
\hline & Medium & 1 & 4 & 17 & $238.6 \pm 75.0$ & $286.7 \pm 40.7$ & $1.20 \pm 0.1$ & $1.28 \pm 0.1$ \\
\hline & High & 2 & 3 & 6 & & & & \\
\hline
\end{tabular}

Table 4. Comparative results for attempt proportion and attempt number among species. $P$-value $(P)$ between parenthesis and significant differences represented by letters. Number of attempts: mean \pm SE.

\begin{tabular}{|c|c|c|c|c|}
\hline \multirow[t]{2}{*}{ Species } & \multicolumn{2}{|c|}{$\begin{array}{l}\text { Attempt }- \text { not attempt } \\
(\% \text { attempting }) \\
(P=0.340)\end{array}$} & \multicolumn{2}{|c|}{$\begin{array}{c}\text { Number of attempts } \\
\left.\text { (n attemptso } \mathrm{n} \text { fish with attempt }{ }^{-1}\right) \\
(P<0.001)\end{array}$} \\
\hline & $\%$ & Tukey's HSD test & Mean \pm SE & Tukey's HISD test \\
\hline Brown trout & $38.8 \%$ & $\mathrm{a}$ & $1.4 \pm 0$ & $\mathrm{a}$ \\
\hline Barbel & $58.8 \%$ & $\mathrm{~b}$ & $3.8 \pm 0$ & $\mathrm{~b}$ \\
\hline Nase & $50.0 \%$ & $\mathrm{a}$ & $2.0 \pm 0$ & $\mathrm{a}$ \\
\hline
\end{tabular}

included as censored observations, with attempt time equal to the duration of the trial (Castro-Santos, 2004; Castro-Santos et al., 2013).

\subsubsection{Passage analysis}

Of those fish that staged attempts, passage performance was analyzed using three additional metrics: (1) success: proportion of ascending fish that reached the uppermost antenna statistically analyzed with logistic regression; (2) height exceeded: proportion of fish exceeding a specific height, censoring fish that reached the uppermost antenna - height $=1 \mathrm{~m}$; and (3) transit time: minimum time to travel between the lowest and uppermost antenna - analyzed using stratified proportional hazard regression. In each case effect of flow discharge on performance were measured.

All statistical analyses were performed using SAS software (version 9.4).

\section{Results}

Brown trout trials were conducted between 26-November and 2-December, 2010; barbel and nase were tested together in trials conducted between 31-May and 5-June, 2011 (Table 1). Water temperature fluctuated over the course of each day. During the brown trout experiments it ranged from $2.8-5.6^{\circ} \mathrm{C}$ and during the cyprinid experiments it ranged from $7.6-12.0^{\circ} \mathrm{C}$.
Oxygen saturation was $100 \%$ and $\mathrm{pH}$ varied from 7.9 to 8.1 . Suspended sediments were always less than $5 \mathrm{mg} \cdot \mathrm{L}^{-1}$.

Water velocity in the slots was different depending on the fishway flow and the local bottom slope (Table 2). Flow was obtained through dilution gauging, using Rhodamine WT, replicating the hydraulic conditions of the experiment without fish. Maximum velocity always occurred on the sixth slot, where slope exceeded 9\%. The lower notches showed slower velocities, because they were influenced by the backwater level in the river, increasing their depth and decreasing the drop between pools.

A total of 20 trout, 17 barbel, and 8 nase were tested in the fishway (Table 3). Nase were slightly larger than barbel, and both cyprinids were slightly larger than trout, but this difference was not significant $(P>0.127)$.

\subsection{Motivation analysis}

Motivation varied by species (Table 4). Barbel and nase appeared to be more motivated than brown trout: they made more attempts $(P<0.001)$ and had a greater proportion attempting, although difference in proportion was not significant $(P=0.340)$. The cyprinids staged attempts sooner than the trout $(P<0.001)$ (Figure 3$)$, and barbel staged their attempts sooner than nase $(P=0.015)$.

Discharge affected motivation of both trout and barbel (Table 5). More trout staged attempts at high flows than at low or medium flows, although significance was marginal: 


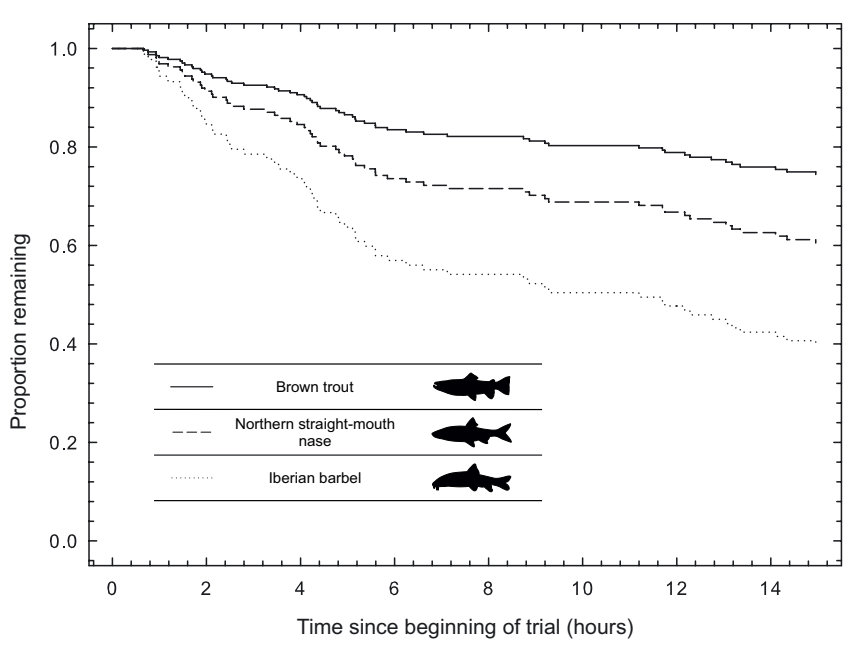

Fig. 3. Survivorship curves showing time to stage the first attempt. Curves are depletion functions, showing the effects of different attempt rates - barbel had the fastest attempt rate and so produced a greater proportion attempting.

Table 5. $P$-values of the effect of flow discharge on motivation intraspecific metrics.

\begin{tabular}{|l|c|c|c|}
\cline { 2 - 4 } \multicolumn{1}{c|}{} & \multicolumn{3}{|c|}{ Motivation parameter (P-values) } \\
\cline { 2 - 4 } \multicolumn{1}{c|}{} & $\begin{array}{c}\text { Attempt-not } \\
\text { attempt }\end{array}$ & $\begin{array}{c}\text { Number of } \\
\text { attempts }\end{array}$ & $\begin{array}{c}\text { Attempt } \\
\text { rate }\end{array}$ \\
\hline Brown trout & 0.055 & 0.844 & 0.096 \\
Barbel & 0.924 & 0.004 & 0.005 \\
Nase & 0.880 & 0.528 & 0.301 \\
\hline
\end{tabular}

$P=0.055$ and Logistic regression coefficient \pm SE value for proportion attempting parameter at high flow $=1.235 \pm 0.597$; and $P=0.096$ and attempt rate hazard model coefficient at high flow $=0.716 \pm 0.402$.

Among barbel the number of attempts was greatest at the medium flow condition $(P=0.004$; mean attempts \pm SE value at medium flow $=5.40 \pm 0.58$; high flow $=2.89 \pm 0.61$; low flow $=2.89 \pm 0.48)$ and the attempt rate was faster $(P=0.005$; coefficients for high flow $=-0.654 \pm 0.250$ and low flow $=$ $-0.690 \pm 0.251)$.

\subsection{Passage analysis}

\subsubsection{Success}

Success rates (n success $\cdot \mathrm{n}$ attempts ${ }^{-1}$ ) were similar among species $(P=0.989$; trout $=0.70$, barbel $=0.71$, nase $=0.70)$. Trout had the lowest success at the highest flows $(P=0.029)$.

\subsubsection{Height exceeded}

Another index of passage is the proportion of fish ascending to a given height. Although most of the fish that made some attempt reached the upper level, not all of them were successful within $24 \mathrm{~h}$ of testing.

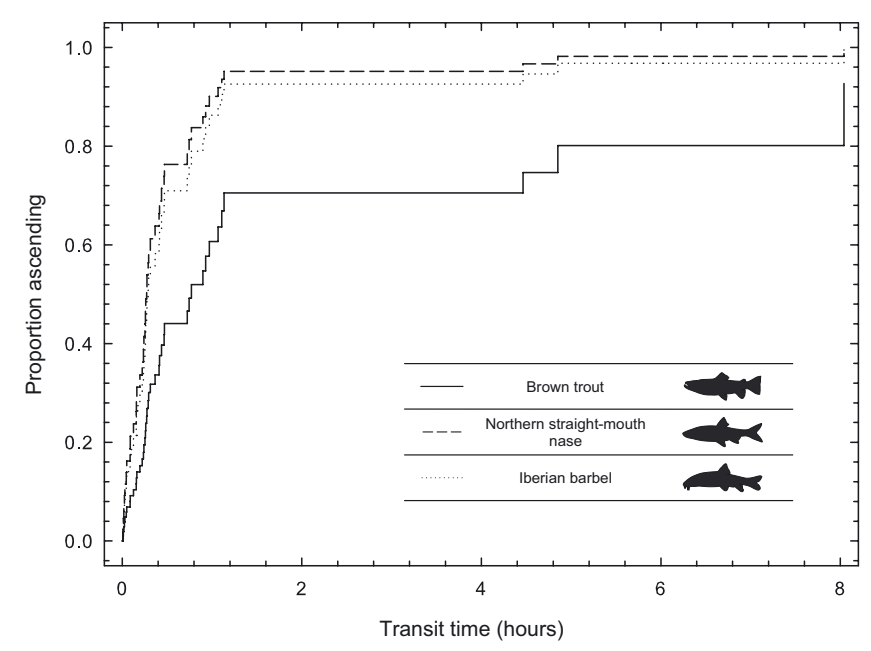

Fig. 4. Relative frequency of transit time for trout, nase and barbel.

There were no significant differences among all three species $(P=0.217)$. The small sample size for nase may be obscuring an effect however: failure rate for trout was greater than for barbel by $71 \%$ per meter of elevation, although this result was only marginally significant $(P=0.082)$. Flow rate influenced ascent, but only among trout, which ascended furthest under medium and low discharges $(P=0.042)$.

\subsubsection{Transit time}

Transit time data did not follow a normal distribution. Therefore, the median, and not the mean, was used as a representative information.

Transit time of rheophilic cyprinids were similar $(P=$ $0.624)$ probably due to small sample size (Median of transit time: barbel $=1013 \mathrm{~s}$ and nase $=322 \mathrm{~s}$ ) and both species ascended the fish ladder faster than trout (Figure 4) $(P=$ 0.012; median of transit time for trout $=2090 \mathrm{~s})$. Post-hoc tests showed significant differences between trout and barbel $(P=0.008)$ and between trout and nase $(P=0.011)$. Transit time was unaffected by fishway discharge.

\section{Discussion}

This study has shown that both barbel and nase were better able to pass a vertical slot fishway than brown trout, and that superior performance appeared to be more driven by motivation than by actual ability to ascend the structure once fish passed the first slot. This contradicts a widespread expectation that trout perform better at passing fishways than rheophilic cyprinids. This expectation led to recommendations that fishway designs for barbel and nase be less challenging than those for trout (Puertas et al., 2012).

These expectations led to recommendations that fishway designs for barbel and nase be less challenging than those for trout (Puertas et al., 2012).

These expectations and recommendations were founded in part on the belief that cyprinids are weaker swimmers than trout. This has been discredited: sprinting ability of barbel and 
nase is very similar to that of trout (Castro-Santos et al., 2013; Sanz-Ronda et al., 2015), and the low expectations of these two species appear to be unjustified.

Having once started the ascent, the three species showed remarkable similarities in their likelihood of passage success. Difference in performance was still evident, however, with the cyprinids passing much more quickly than the trout. It is likely that the reduced motivation and transit time exhibited by the trout was related in part to the lower temperatures experienced by that species. Motivation is one of the key factors driving passage performance, although it is rarely measured (Castro-Santos, 2004; Wagner et al., 2012; Cooke and Hinch, 2013). Tagging and handling may also influence motivation. We expect this to produce conservative results, however and do not believe this influences the conclusions of this study.

At lower temperatures metabolic rates and sustained swim speeds are both reduced (Brett, 1964; Beamish, 1978; McKenzie and Claireaux, 2010; Yan et al., 2012). Several species of fish have been shown to exhibit reduced attempt rates at lower temperatures (Castro-Santos, 2002; CastroSantos, 2004). These studies were performed during the period when all species were undergoing spawning migrations, however, and so the reduced performance of trout holds importance for their management and conservation.

Fishway discharge influenced overall ascent ability. It affected motivation, although it did not influence passage, except by delaying increased transit time for trout in high flows. Motivation of barbel was higher at medium flows, and for trout it was greater at high flows. Increased motivation in response to elevated velocities and flows has been widely reported in fishway and swimming flume studies(Weaver, 1963; CastroSantos, 2004; Castro-Santos et al., 2013).

Generally, in vertical slot fishways, the slot velocities are relatively unaffected by discharge (Rodríguez et al., 2006). Nevertheless, we observed changes in water velocity at the slots when flow increased in the fishway - it enlarged about $20 \%$ from low to high discharge - and also in the main recirculation areas at pools. It is likely that the changed behavior is a response to these factors.

Finally, a fact that is manifested in this experiment, as well as in similar ones, is the strong variation of the transit time, which was strongly skewed toward longer times, producing a large difference between mean and median (Gowans et al., 1999; White et al., 2010).

This suggests that the transit time depends more on the individuals own behavior than events dependent on factors under study. In addition, the median is the index that best represents the behavior of the sample. The distribution of transit times is consistent with diffusion theory (Castro-Santos et al., 2009), and is one reason that survival analysis techniques typically model the logarithm of time or of the hazard (event rate). Skewed distributions also indicate that movement is not strongly directed, and are characteristic of structures that impart reduced rates of movement, increased tortuosity, or migratory delay (Castro-Santos and Haro, 2003).

As with most fish species, further research is needed on the interplay between swimming abilities, migration habits and behavior inside fish passes of Iberian native species and specifically for cyprinids. If similar studies are performed over a range of fishway designs and sizes it will become possible to improve both performance and cost-effectiveness of engineered fish passage structures.

Acknowledgements. This research has been supported by Castilla y León Regional Government: project VA299B11-2: "Swimming capacity evaluation in Iberian fish". Francisco Javier Bravo-Córdoba is supported by a Ph.D. grant from the University of Valladolid PIFUVa 2011. León Fisheries Service facilitated their installations and staff for experimentation. We specially thank to the research group GEA-Ecohidráulica their help on fieldwork.

\section{References}

Alexandre C., Quintella B.R., Silva A., Mateus C., Romão F., Branco P., Ferreira M.T. and Almeida P.R., 2013. Use of electromyogram telemetry to assess the behavior of the Iberian barbel (Luciobarbus bocagei Steindachner, 1864) in a pool-type fishway. Ecol. Eng., 51, 191-202.

Armstrong G., Aprahamian M., Fewings G., Gough P., Reader N. and Varallo P., 2004. Environment agency fish pass manual: guidance notes on the legislation, selection and approval of fish passes in England and Wales, Environment Agency. Wales, UK.

Beamish F., 1978. Swimming capacity, locomotion. In: Hoar W.S. and Randall D.J. (eds.), Fish Physiology. Vol. VII, pp. 101-187.

Branco P., Santos J.M., Katopodis C., Pinheiro A. and Ferreira M.T., 2013. Effect of flow regime hydraulics on passage performance of Iberian chub (Squalius pyrenaicus) (Günther, 1868) in an experimental pool-and-weir fishway. Hydrobiologia, 714, 145-154.

Brett J.R., 1964. The respiratory metabolism and swimming performance of young sockeye salmon. J. Fish. Res. Board Can., 21, $1183-1226$.

Bunt C.M., Castro-Santos T. and Haro A., 2011. Performance of fish passage structures at upstream barriers to migration. River Res. Appl., 28, 457-478.

Castro-Santos T., 2002. Swimming performance of upstream migrant fishes: new methods, new perspectives, Doctoral dissertation, University of Massachusetts Amherst.

Castro-Santos T., 2004. Quantifying the combined effects of attempt rate and swimming capacity on passage through velocity barriers. Can. J. Fish. Aquat. Sci., 61, 1602-1615.

Castro-Santos T., 2005. Optimal swim speeds for traversing velocity barriers: an analysis of volitional high-speed swimming behavior of migratory fishes. J. Exp. Biol., 208, 421-432.

Castro-Santos T. and Haro A., 2003. Quantifying migratory delay: a new application of survival analysis methods. Can. J. Fish. Aquat. Sci., 60, 986-996.

Castro-Santos T. and Haro A. 2010. Fish guidance and passage at barriers. In: Domenici P.B. and Kapoor B.G. (eds.), Fish Locomotion: An Eco-ethological Perspective, Science Publishers, 48-62.

Castro-Santos T. and Perry R.W., 2012. Time-to-event analysis as a framework for quantifying fish passage performance. In: Telemetry techniques: a user guide for fisheries research. American Fisheries Society, Bethesda, Maryland, 427-452.

Castro-Santos T. and Vono V., 2013. Posthandling Survival and PIT Tag Retention by Alewives-A Comparison of Gastric and Surgical Implants. N. Am. J. Fish. Manage., 33, 790-794.

Castro-Santos T., Haro A. and Walk S., 1996. A passive integrated transponder (PIT) tag system for monitoring fishways. Fish. Res., $28,253-261$. 
Castro-Santos T., Cotel A. and Webb P., 2009. Fishway evaluations for better bioengineering: an integrative approach. Challenges for Diadromous Fishes in a Dynamic Global Environment, 557.

Castro-Santos T., Sanz-Ronda J. and Ruiz-Legazpi J., 2013. Breaking the speed limit-comparative sprinting performance of brook trout (Salvelinus fontinalis) and brown trout (Salmo trutta). Can. J. Fish. Aquat. Sci., 70, 280-293.

Clay, C. H. 1995. Design of Fishways and Other Fish Facilities. Lewis Publishers. Ann Arbor, MI.

Clough S., Lee-Elliott I., Turnpenny A., Holden S. and Hinks C., 2004. Swimming speeds in fish: phase 2. R\&D Technical Report W2-049/TR1. Environment Agency, Bristol.

Cooke S.J. and Hinch S.G., 2013. Improving the reliability of fishway attraction and passage efficiency estimates to inform fishway engineering, science, and practice. Ecol. Eng., 58, 123-132.

Council E., 1986. EEC Council Directive 86/609/EEC of 24 November 1986 on the approximation of laws, regulations and administrative provisions of the Member States regarding the protection of animals used for experimental and other scientific purposes. 358, 1-28.

Doadrio I., 2001. Atlas y libro rojo de la ictiofauna continental española, NIMAM-CSCI, Madrid.

Doadrio I., Perea S., Garzón-Heydt P. and González Y.J.L., 2011. Ictiofauna continental española. Bases para su seguimiento.Ministerio de Medio Ambiente y Medio Rural y Marino, Centro de Publicaciones.

Elvira B., Almodóvar A. and Nicola G.G., 1998. Impacto de las obras hidráulicas en la ictiofauna: Dispositivos de paso para peces en las presas de España, Organismo Autónomo Parques Nacionales, Madrid.

Ficke A.D., Myrick C.A. and Kondratieff M.C., 2012. The effects of PIT tagging on the swimming performance and survival of three nonsalmonid freshwater fishes. Ecol. Eng., 48, 86-91.

Franklin A.E., Haro A., Castro-Santos T. and Noreika J., 2012. Evaluation of nature-like and technical fishways for the passage of alewives at two coastal streams in New England. Trans. Am. Fish. Soc., 141, 624-637.

Gowans A.R., Armstrong J.D. and Priede I.G., 1999. Movements of adult Atlantic salmon in relation to a hydroelectric dam and fish ladder. J. Fish Biol., 54, 713-726.

James R.S. and Johnston I.A., 1998. Influence of spawning on swimming performance and muscle contractile properties in the shorthorn sculpin. J. Fish Biol., 53, 485-501.

Larinier M., 2002a. Biological factors to be taken into account in the design of fishways, the concept of obstructions to upstream migration. Bull. Fr. Pêche Pisc., 364, 28-38.

Larinier M., 2002b. Pool fishways, pre-barrages and natural bypass channels. Bull. Fr. Pêche Pisc., 364, 54-82.

Makrakis S., Miranda L.E., Gomes L.C., Makrakis M.C. and Junior H.M., 2010. Ascent of neotropical migratory fish in the Itaipu Reservoir fish pass. River Res. Appl., 27, 511-519.

Mallen-Cooper M., 1999. Developing fishways for non-salmonid fishes: a case study from the Murray River in Australia. Innovations in Fish Passage Technology, 173.

Mallen-Cooper M. and Brand D.A., 2007. Non-salmonids in a salmonid fishway: what do 50 years of data tell us about past and future fish passage? Fish Manage. Ecol., 14, 319-332.

Mateus C.S., Quintella B.R. and Almeida P.R., 2008. The critical swimming speed of Iberian barbel Barbus bocagei in relation to size and sex. J. Fish Biol., 73, 1783-1789.
McKenzie D.J. and Claireaux G. 2010. Effects of environmental factors on the physiology of sustained aerobic exercise. In: Fish Locomotion-an ethoecological perspective. Science Publishers, New Hampshire, 296-332.

Noonan M.J., Grant J.W. and Jackson C.D., 2012. A quantitative assessment of fish passage efficiency. Fish Fish., 13, 450-464.

Ostrand K.G., Zydlewski G.B., Gale W.L. and Zydlewski J.D., 2011. Long term retention, survival, growth, and physiological indicators of juvenile salmonids marked with passive integrated transponder tags. American Fisheries Society Symposium, 76.

Pedersen L., Koed A. and Malte H., 2008. Swimming performance of wild and F1-hatchery-reared Atlantic salmon (Salmo salar) and brown trout (Salmo trutta) smolts. Ecol. Freshwat. Fish, 17, 425-431.

Plaut I., 2002. Does pregnancy affect swimming performance of female Mosquitofish, Gambusia affinis? Funct. Ecol., 16, 290-295.

Pompeu P. and Martinez C.B., 2007. Swimming performance of the migratory Neotropical fish Leporinus reinhardti (Characiformes: Anostomidae). Neotrop. Ichthyol., 5, 139-146.

Puertas J., Cea L., Bermúdez M., Pena L., Rodríguez Á, Rabuñal J.R., Balairón L., Lara Á and Aramburu E., 2012. Computer application for the analysis and design of vertical slot fishways in accordance with the requirements of the target species. Ecol. Eng., 48, 51-60.

Rajaratnam N., Van der Vinne G. and Katopodis C., 1986. Hydraulics of vertical slot fishways. J. Hydraul. Eng., 112, 909-927.

Rodríguez T.T., Agudo J.P., Mosquera L.P. and González E.P., 2006. Evaluating vertical-slot fishway designs in terms of fish swimming capabilities. Ecol. Eng., 27, 37-48.

Romão F., Quintella B.R., Pereira T.J. and Almeida P.R., 2012. Swimming performance of two Iberian cyprinids: the Tagus nase Pseudochondrostoma polylepis (Steindachner, 1864) and the bordallo Squalius carolitertii (Doadrio, 1988). J. Appl. Ichthyol., 28, 26-30.

Rosgen D.L. and Silvey H.L., 1996. Applied river morphology, Wildland Hydrology Pagosa Springs, Colorado.

Sanz-Ronda F.J., Bravo-Córdoba F.J. and Martínez de Azagra A., 2010. Estaciones de aforo V-flat y peces migradores de la Península Ibérica: problemas y soluciones. Ingeniería Civil, 158, 111-119.

Sanz-Ronda F.J., Ruiz-Legazpi J., Bravo-Córdoba F.J., Makrakis S. and Castro-Santos T., 2015. Sprinting performance of two Iberian fish: Luciobarbus bocagei and Pseudochondrostoma duriense in an open channel flume. Ecol. Eng., 83, 61-70.

Silva A.T., Santos J.M., Franco A.C., Ferreira M.T. and Pinheiro A.N., 2009. Selection of Iberian barbel Barbus bocagei (Steindachner, 1864) for orifices and notches upon different hydraulic configurations in an experimental pool-type fishway. J. Appl. Ichthyol., 25, 173-177.

Silva A.T., Katopodis C., Santos J.M., Ferreira M.T. and Pinheiro A.N., 2012. Cyprinid swimming behaviour in response to turbulent flow. Ecol. Eng., 44, 314-328.

Stuart I.G. and Berghuis A.P., 2002. Upstream passage of fish through a vertical-slot fishway in an Australian subtropical river. Fish. Manage. Ecol., 9, 111-122.

Thiem J.D., Broadhurst B.T., Lintermans M., Ebner B.C., Clear R.C. and Wright D., 2013. Seasonal differences in the diel movements of Macquarie perch (Macquaria australasica) in an upland reservoir. Ecol. Freshwat. Fish, 22, 145-156.

Travade F. and Larinier M., 2002. Monitoring techniques for fishways. Bull. Fr. Pêche Pisc., 364, 166-180. 
Wagner R.L., Makrakis S., Castro-Santos T., Makrakis M.C., Pinheiro J.H. and Belmont R.F., 2012. Passage performance of long-distance upstream migrants at a large dam on the Paraná River and the compounding effects of entry and ascent. Neotrop. Ichthyol., 10, 785-795.

Wang R.W., David L. and Larinier M., 2010. Contribution of experimental fluid mechanics to the design of vertical slot fish passes. Knowl. Manag. Aquat. Ecosyst., 396, 02.
Weaver C.R., 1963. Influence of water velocity upon orientation and performance of adult migrating salmonids. Fish. Bull., 63, 24.

White L.J., Harris J.H. and Keller R.J., 2010. Movement of three nonsalmonid fish species through a low-gradient vertical-slot fishway. River Res. Appl., 27, 499-510.

Yan G.J., He X.K., Cao Z.D. and Fu S.J., 2012. The trade-off between steady and unsteady swimming performance in six cyprinids at two temperatures. J. Therm. Biol., 37, 424-431.

Cite this article as: F.J. Sanz-Ronda, F.J. Bravo-Córdoba, J.F. Fuentes-Pérez and T. Castro-Santos, 2016. Ascent ability of brown trout, Salmo trutta, and two Iberian cyprinids - Iberian barbel, Luciobarbus bocagei, and northern straight-mouth nase, Pseudochondrostoma duriense - in a vertical slot fishway. Knowl. Manag. Aquat. Ecosyst., 417, 10. 